\title{
Timing Of The Deposition Of Uppermost Cretaceous And Paleocene Coal-Bearing Deposits In The Greater Glendive Area, Montana And North Dakota
}

Topical Report

December 29, 1995

February 16, 1996

Work Performed Under Contract No.: DE-FC21-93MC30098

For

U.S. Department of Energy

Office of Fossil Energy

Morgantown Energy Technology Center

Morgantown, West Virginia

By

University of North Dakota

Energy \& Environmental Research Center

Grand Forks, North Dakota

DISTRIBUTION OF THIS DOCUMENT IS UNLIMTTED 


\section{DISCLAIMER}

This report was prepared as an account of work sponsored by an agency of the United States Government. Neither the United States Government nor any agency thereof, nor any of their employees, makes any warranty, express or implied, or assumes any legal liability or responsibility for the accuracy, completeness, or usefulness of any information, apparatus, product, or process disclosed, or represents that its use would not infringe privately owned rights. Reference herein to any specific commercial product, process, or service by trade name, trademark, manufacturer, or otherwise does not necessarily constitute or imply its endorsement, recommendation, or favoring by the United States Government or any agency thereof. The views and opinions of authors expressed herein do not necessarily state or reflect those of the United States Government or any agency thereof.

Available to the public from the National Technical Information Service, U.S. Department of Commerce, 5285 Port Royal Road, Springfield, VA 22161; phone orders accepted at (703) 487-4650. 


\section{Timing Of The Deposition Of Uppermost Cretaceous And Paleocene Coal-Bearing Deposits In The Greater Glendive Area, Montana And North Dakota}

Topical Report

December 12, 1996

Work Performed Under Contract No.: DE-FC21-93MC30098

For

U.S. Department of Energy

Office of Fossil Energy

Morgantown Energy Technology Center

P.O. Box 880

Morgantown, West Virginia 26507-0880

By

University of North Dakota

Energy \& Environmental Research Center

P.O. Box 9018

Grand Forks, North Dakota 58202-9018

February 1996 


\section{DISCLAIMER}

Portions of this document may be illegible in electronic image products. Images are produced from the best available original document. 
ABSTRACT $\ldots \ldots \ldots \ldots \ldots \ldots \ldots \ldots \ldots \ldots \ldots \ldots \ldots \ldots \ldots \ldots \ldots \ldots \ldots \ldots$ ABBREVIATIONS AND NOTES $\ldots \ldots \ldots \ldots \ldots \ldots \ldots \ldots \ldots \ldots \ldots$ OVERVIEW OF COLLABORATION AND SUPPORT $\ldots \ldots \ldots \ldots \ldots \ldots \ldots \ldots$ v PROJECT OBJECTIVE $\ldots \ldots \ldots \ldots \ldots \ldots \ldots \ldots \ldots \ldots \ldots \ldots \ldots \ldots \ldots \ldots \ldots \ldots$ APPLICABILITY TO FOSSIL ENERGY OBJECTIVES $\ldots \ldots \ldots \ldots \ldots \ldots \ldots$ SUMMARY OF THE PROBLEM $\ldots \ldots \ldots \ldots \ldots \ldots \ldots \ldots \ldots \ldots$

INTRODUCTION $\ldots \ldots \ldots \ldots \ldots \ldots \ldots \ldots \ldots \ldots \ldots \ldots \ldots \ldots \ldots \ldots \ldots \ldots \ldots \ldots$

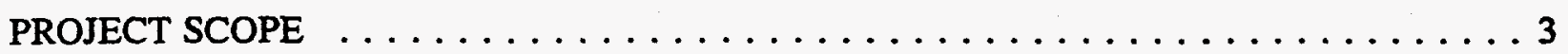

SPECIFIC OBJECTIVES $\ldots \ldots \ldots \ldots \ldots \ldots \ldots \ldots \ldots \ldots \ldots \ldots$

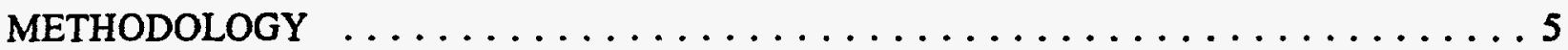

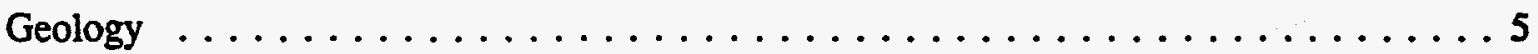

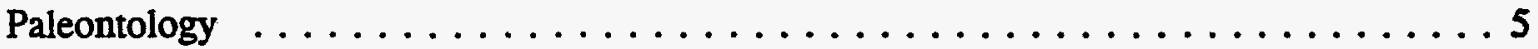

EXPLANATION AND SUMMARY OF FINDINGS $\ldots \ldots \ldots \ldots \ldots \ldots \ldots \ldots$

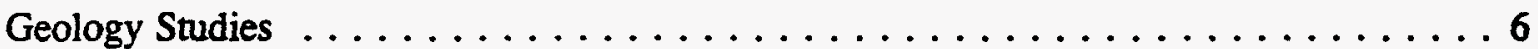

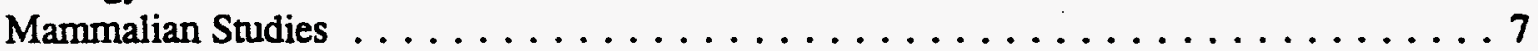

Molluscan Studies $\ldots \ldots \ldots \ldots \ldots \ldots \ldots \ldots \ldots \ldots \ldots$

Williston Basin Correlations $\ldots \ldots \ldots \ldots \ldots \ldots \ldots \ldots \ldots$

STATEMENT OF RESULTS $\ldots \ldots \ldots \ldots \ldots \ldots \ldots \ldots \ldots \ldots \ldots$

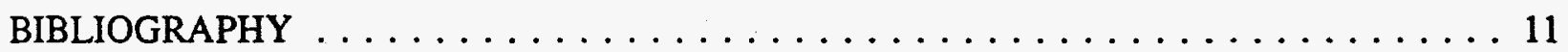

FIGURE CAPTIONS $\ldots \ldots \ldots \ldots \ldots \ldots \ldots \ldots \ldots \ldots \ldots \ldots \ldots$

SUMMARY INFORMATION ON MAMMALIAN FOSSIL LOCALITIES, GLENDIVE

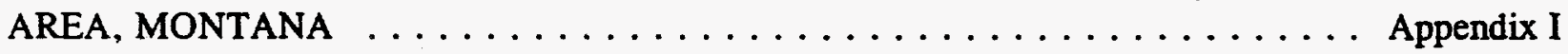

MAMMALIAN FAUNAS FOR FOSSILIFEROUS STRATA, GLENDIVE AREA,

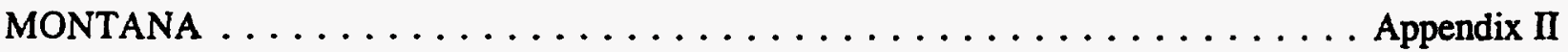
STRATIGRAPHIC SECTIONS FOR SIGNIFICANT LOCALITIES IN MAKOSHIKA STATE PARK $\ldots \ldots \ldots \ldots \ldots \ldots \ldots \ldots \ldots \ldots \ldots \ldots \ldots \ldots \ldots \ldots \ldots \ldots \ldots \ldots$ Appendix III 


\section{LIST OF FIGURES}

1 Williston Basin Glendive area studies, Dawson County, Montana . . . . . . . . . 21

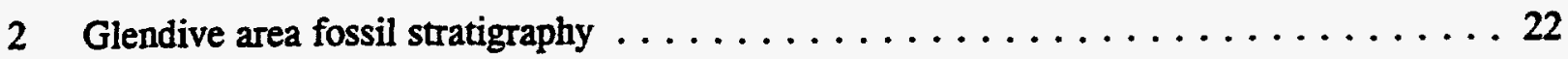

3 Glendive area - Makoshika State Park fossil localities, Dawson County, Montana . . . . 23

4 Makoshika State Park - Muddy Tork and Hiatt area fossil localities . . . . . . . . 24

5 Stratigraphy of fossil localities in Sec. 1, T. 15 N., R. 55 E., Makoshika State Park, Montana ............................ 25

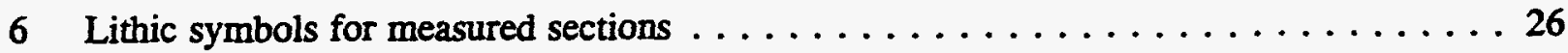

7 Muddy Tork Locality, Makoshika State Park, Montana . . . . . . . . . . . 27

8 Muddy Tork Locality, Makoshika State Park, Montana . . . . . . . . . . . . 28

9 .Witches Hat sections, Makoshika State Park, Montana . . . . . . . . . . . . . . . 29

10 Paleomagnetic, fern spike, K/T boundary sections, Makoshika State Park, Montana . . 30

11 Fern spike locality, K/T boundary Interval, Makoshika State Park, Montana . . . . . 31

12 The placement of the $\mathrm{K} / \mathrm{T}$ boundary in Makoshika State Park, Montana . . . . . . . . . 32

13a K/T boundary fern spike, Makoshika State Park, Montana . . . . . . . . . . 33

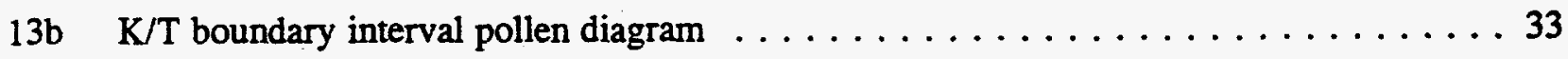

14 Sand Creek Overlook sections, Makoshika State Park, Montana . . . . . . . . . . . . . 34

15 Paleomagnetic stratigraphy - fern spike section, Makoshika State Park, Montana . . . 35

16 Paleomagnetic data for Section M7887b, Makoshika State Park, Montana . . . . . . 36

17 Hiatt and Hiatt South Localities, Makoshika State Park, Montana . . . . . . . . . . 37

18 Hiatt South Locality, Makoshika State Park, Montana . . . . . . . . . . . . . . . . 38

19 Bulk sediment screen washing, Yellowstone River, Glendive, Montana . . . . . . . . 39

20 Chronostratigraphy of North Dakota strata $\ldots \ldots \ldots \ldots \ldots \ldots \ldots$ 


\title{
TIMING OF THE DEPOSITION OF UPPERMOST CRETACEOUS AND PALEOCENE COAL-BEARING DEPOSITS IN THE GREATER GLENDIVE AREA, MONTANA AND NORTH DAKOTA
}

\begin{abstract}
With the aid of a grant from the National Geographic Society, a cooperative agreement with the State University of New York at Stony Brook, and contract with the U.S. Department of Energy, Late Cretaceous and Paleocene geologic and paleontologic field studies were undertaken in Makoshika State Park and vicinity, Dawson County, Montana. This region was chosen as a study area because of its potential for yielding new fossil localities and extensive exposures both above and below the $\mathrm{K} / \mathrm{T}$ boundary, as suggested by previous research by David W. Krause and Joseph H. Hartman. Related field studies were also undertaken in areas adjacent to the Cedar Creek Anticline in North Dakota. This work was part of ongoing research to document change in the composition of mammalian and molluscan faunas during the Late Cretaceous and Paleocene and to relate observed patterns to floral and invertebrate changes in composition.
\end{abstract}

This study focuses on the record of mammals and mollusks in the Makoshika stratigraphic section and places old and new observations into a paleomagnetic and palynomorph framework. Of particular interest is the appearance and diversification of archaic ungulate mammals. Simultaneous dinosaur extinction with ungulate radiation has been invoked in gradual, as opposed to catastrophic, models of faunal change at the $\mathrm{K} / \mathrm{T}$ boundary. However, supposed Cretaceous localities bearing archaic ungulates and other mammals of "Paleocene aspect" may be the product of faunal reworking. Elsewhere in the Williston Basin (e.g., Garfield and McCone Counties, Montana), the molluscan record of uppermost Cretaceous and Paleocene strata indicates the extinction of all of the highly sculptured unionid bivalves just prior to the onset of coal swamps and subsequent coal formation. This event does not appear to be exactly coincident with the K/T impact event and thus may be associated with a large-scale environmental change in some way related to events leading to coal-forming conditions.

The 1993 field season was concerned with the discovery of new mammalian and molluscan localities and the development of a stratigraphic framework for the study. Efforts in 1994 resulted in additional discoveries and large samples of mammalian fossils by concentrating collection activities on the most productive localities. Samples of fossil mammals now have been recovered from new localities of Late Cretaceous and Paleocene age. Of particular significance was the discovery of Hiatt South Locality, which represents a highly productive facies lateral to the previously known Hiatt Locality (early Paleocene). In addition to surface collection, approximately $2200 \mathrm{~kg}$ of matrix were processed for fossils.

The mammalian fauna recovered from horizons in the Upper Cretaceous Hell Creek Formation (Lancian) of Makoshika State Park and vicinity resembles faunas from elsewhere in Montana and Wyoming of Lancian age (Lance Creek and Flat Creek) in composition more than faunas in Alberta and Saskatchewan (Trochu and Gryde). At Makoshika, pediomyid marsupials are diverse, and the multituberculate Meniscoessus is abundant. No eutherians and only one peradectid marsupial, Turgidodon rhaister, have been recovered from these horizons. The mammalian fauna recovered from the lower part of the Paleocene Ludlow Formation resembles 
other northern latitude Puercan faunas in composition. This fauna includes the multinuberculates Neoplagiaulax, Stygimys, and Ectypodus?, the primitive taeniodont Onychodectes, and a diverse assemblage of archaic ungulates, including species of Baioconodon, Eoconodon, Loxolophus, Tinuviel, and Oxyacodon. From the upper part of the Ludlow Formation, the School Well local fauna (Torrejonian) is known as yet from fewer specimens than the other localities. It contains the plesiadapiform Paromomys sp., the multituberculate Ptilodus montanus, and the condylarths Promioclaenus sp. and Litaletes sp.

Strata yielding typical Late Cretaceous mammals are separated from those yielding early Paleocene mammals by about $20 \mathrm{~m}$. The $\mathrm{K} / \mathrm{T}$ boundary in this interval was recognized on the basis of palynomorphs through work conducted at the Energy \& Environmental Research Center. Pollen studies also recorded the preliminary identification of the fern spike, noted elsewhere by others as a $\mathrm{K} / \mathrm{T}$ boundary event. Lack of any type of Bug Creek vertebrate assemblage suggests that the controversial "Bugcreekian" biochron need not be extended into this area. This implies that the adaptive radiation of archaic ungulates may not have begun until after the dinosaur extinction.

Also in 1993 and 1994, sediment samples were taken for paleomagnetic analysis. Lithic samples for paleomagnetic analysis collected in 1993 (Section M6723) did not provide a clear or unambiguous signal of the sequence of paleomagnetic reversals. Sampling in 1994 (Section M7887b), however, permitted the identification of Chron 30n, Chron 29r, and Chron 29n. The results of the analyses of these samples confirm the palynomorph identification of the $\mathrm{K} / \mathrm{T}$ boundary in Chron 29r. The study of the record of reversal stratigraphy also provides a concordant temporal framework to provide additional strength to interpretations regarding mammalian age determinations, placing the middle lower Paleocene mammalian faunas in Chron 29 r.

The record of mollusks in Makoshika State Park is poor to virtually nonexistent. A few specimens of little value were collected from the Cretaceous-age Muddy Tork and Q.V. Localities and Locality L6467, the lowermost Paleocene-age Locality L6260 (just above the Contact lignite), and from the lower Paleocene Hiatt South and Deer Crash Localities and Locality L6425, both of which are at the same level. Most of the specimens are steinkerns of small specimens of mesogastropods of the families Pleuroceridae and Viviparidae. Specimens questionably identified as New Genus A limneaformis (family incertae sedis) were found both below and above the K/T boundary. Freshwater bivalves are represented by only a few specimens. One pisidiid is known from the Hell Creek Formation, and unionid impressions occur just above the Contact lignite. Although of limited systematic or biostratigraphic value, this depauperate fauna is representative of the limited species diversity found at many localities in the lowermost Paleocene in North America. 


\section{ABBREVIATIONS AND NOTES}

The following institutional abbreviations are used in this report: DOE (U.S. Department of Energy), NGS (National Geographic Society), (EERC) Energy \& Environmental Research Center, UND (University of North Dakota, Deparment of Geology and Geological Engineering), SUNYSB (State University of New York at Stony Brook), and USGS (U.S. Geological Survey). Miscellaneous abbreviations include the following: PI (principal investigator), co-PI (coprincipal investigator), and $\mathrm{K} / \mathrm{T}$ (Cretaceous-Tertiary).

All observations were plotted on U.S. Geological Survey 7.5-minute series topographic quadrangles. Geologists of the Montana Bureau of Mines and Geology are in the process of producing a new 1:500,000-scale state geologic map. Earlier preprint versions of maps at various scales were graciously provided by Susan Vuke (also cited as S.M. Vuke-Foster and S.M. Foster). The placement of some lithostratigraphic contacts and member nomenclature were revised subsequent to field work undertaken for this project. These changes have been incorporated in this report for the greater Glendive area, but direct correlation between North Dakota and Montana sections other than the $\mathrm{K} / \mathrm{T}$ boundary interval must await further study.

Fossil locality and geologic observation numbering systems are employed throughout this report. Mammalian localities, as is generally the case, are given names (e.g., Hiatt Locality) for ease of reference. Although they are referred to by name throughout this report, all localities have an L-number for the purposes of computer-based data management (see Appendix I). Except for the co-occurrence of mollusks with mammals, all molluscan localities are simply referred to by an L-number (e.g., L6260). The location and geologic unit data for measured sections are referred to by an M-number (e.g., Section M4763) (see Appendix III). All locality and geologic observation data are maintained in databases designed in Version 4 of $Q_{\& A}{ }^{\circ}$ by Symantec Corporation.

\section{OVERVIEW OF COLLABORATION AND SUPPORT}

This project was undertaken with the support of the DOE and the NGS. The latter grant was facilitated by The Research Foundation of the State University of New York at Stony Brook. The primary investigators were Joseph $\mathrm{H}$. Hartman (PI on the DOE contract to the EERC, co-PI on NGS grant) and David W. Krause (PI on the NGS grant to SUNY-SB). Besides the principal investigators, the following individuals contributed their knowledge, resources, and/or facilities to aid in this research project: John P. Hunter (SUNY-SB), Timothy J. Kroeger (Bemidji State University), Steven P. Lund (University of Southern California), and Allen J. Kihm (Minot State University). The project also included the valuable field and/or laboratory assistance of the following students employed by J.H. Hartman at the EERC: T.J. Kroeger (graduated), Wesley D. Peck (graduated; now EERC staff), Michelle R. Rolland, and Daryl E. Heinen. Those who provided field support by the NGS grant and other support include Tony and Susan Falsetti, Ann Gilmartin, J.P. Hunter, Elizabeth M. McGee, R. Lee Cothran, Karen Samonds, Rob Asher, Suzanne G. Strait, and Roshna Wunderlich.

Geologic interpretations were aided through discussions and correspondence with recent or ongoing studies by Susan Vuke (Montana Bureau of Mines and Geology), Raymond Butler (High Plains Consortium, Inc., late of the EERC), David Fastovsky (University of Rhode Island), 
Cathryn Newton (Syracuse University), Peter Sheehan (Milwaukee Public Museum), and Rob Kukowski (late of Makoshika State Park).

Important services and other forms of cooperation were also provided by Sam Undem, Chris Undem, and Joseph Blankenship of Glendive, Montana, and other ranchers who permitted access to their property for these studies. Other forms of assistance were rendered by Robert Hiatt of Glendive and Makoshika State Park rangers Mike Sullivan and Rob Kukowski. Wilbur Wallace (City of Glendive), Gary Kirkpatrick (US West), and Lois Ferguson (private land owner) kindly provided access to the top of Hungry Joe plateau. Access to study and collect fossils and sediment samples in Makoshika State Park was provided by the Montana Department of Fish, Wildlife \& Parks. Appreciation is also expressed to Lance Phinney, who allowed use of the facilities at the Lions Camp in Makoshika State Park. 


\section{TIMING OF THE DEPOSTIION OF UPPERMOST CRETACEOUS AND PALEOCENE COAL-BEARING DEPOSITS IN THE GREATER GLENDIVE AREA, MONTANA AND NORTH DAKOTA}

\section{PROJECT OBJECTIVE}

This research concerns determination of the timing of coal deposition in the Fort Union Coal Region, as developed in the Glendive and adjacent areas in Montana and North Dakota (Figure 1). The project objective is to develop a time framework that allows for the temporal comparison of coal deposits and thus coal-forming conditions through the transition from non-coal-bearing to coal-bearing deposits in the Fort Union Coal Region. Such a regional coal chronostratigraphic (time-rock) framework permits local and regional interpretations of environments of coal deposition controlling coal quality and thickness, thus contributing significantly to effective resource evaluation and utilization.

\section{APPLICABILITY TO FOSSIL ENERGY OBJECTIVES}

This research is part of a larger program designed to provide information on the timing of deposition of coal beds in the Fort Union Coal Region. Such temporal data provide both a means and a framework to reconstruct the depositional history of coal. The derived chronostratigraphic foundation represents an earth-based, or natural, organizational system in which to place associated coal composition and quality data that are especially important in making soundly based decisions regarding coal extraction and utilization. Temporal characterization of coal-bearing strata is especially critical in considerations specific to nonstrippable coal, which represents the bulk (about 95 percent; see data in Averitt, 1975) of North Dakota coal resources and in which interest will increase as more accessible resources are depleted. Thus this study provides information of value to secure future energy supplies by expanding the recoverable coal resource through an understanding of when and how the peat that formed the coal deposit accumulated.

\section{SUMMARY OF THE PROBLEM}

Effective and efficient utilization of coal resources depends on appropriate characterization. To date, coal analysis and coal resource assessment have almost exclusively been conducted without regard for an understanding of the regional geologic setting and specific paleoenvironmental context. Varying coal composition and quality are documented largely as analytical results without reference to their environmental meaning or representation as environment trends. Coal sample characterization without temporal and geologic context represents isolated observations that are generally incapable of providing information that would lead to a determination of regional trends in coal distribution, geochemistry, preservation, and thickness. Expensive drilling programs provide valuable coal correlation data, but without an understanding of the timing of coal deposition, the reconstruction of paleoenvironments may easily compare coals of different times, thus leading to incorrect relationships and inaccurately interpreted environmental conditions. Changes in climates, vegetation and vegetational patterns, and past land and water configurations produce different depositional histories. Presently, an understanding of

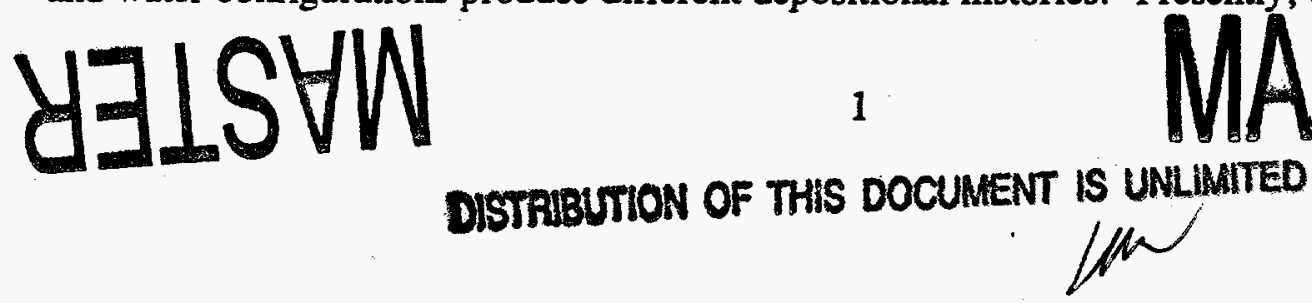


trends in coal quality is made almost impossible by the absence of context for many, if not most, coal sample observations in the Fort Union Coal Region (Hartman, 1992b).

\section{INTRODUCTION}

The jointly sponsored research supports a number of activities that directly bear on providing a more thorough understanding of the transition between the Cretaceous and Tertiary periods of geologic time. This time boundary is well known to both the scientific community and the general public because of its association with the extinction of the dinosaurs (and many other plant and animal groups) and a bolide (large meteor) impact(s). In terms of mammalian evolution, the beginning of the Tertiary represents a time of diversification. At the beginning of the existence of coal-forming environments in the Tertiary, there were only four major groups of mammals, but by the end of 10 million years of Paleocene peat accumulation in the northern Great Plains, the mammalian fauna included 20 major groups, representing most of the mammalian orders seen today.

Across the K/T boundary in the northern Great Plains, a major change is also recorded in the deposition of sediments. This change, simply put, is from non-coal-forming environments to conditions under which peat accumulation was commonplace. The few coal beds that occur in the Upper Cretaceous are thin and insignificant. The coal beds of the northern Great Plains, representing the ancient drainage systems of what are now northeastern Wyoming, eastern Montana, southern Saskatchewan, and western North Dakota, are part of the basal epoch (or series) of the Tertiary known as the Paleocene. The Fort Union Coal Region takes its name from the Fort Union Formation (or Group as used in North Dakota) that includes most of the coalbearing strata of the Paleocene (about 65 to 55 million years before present). As originally introduced by Meek and Hayden in 1862, the Fort Union Group was synonymous with the Great Lignite Basin (= Williston Basin). The Fort Union Group formations of specific interest to this study include the uppermost Cretaceous (= Lancian age) Hell Creek Formation and the overlying lower Paleocene (= Puercan age) Ludlow Formation (equivalent elsewhere to the Tullock).

This project is part of an EERC research program designed to document the timing of the deposition of peat in the Fort Union Coal Region. Temporal, or time-rock, data provide a means to relate the history of coal-bearing deposition across an entire region or between regions. Temporal data are primarily derived from the sequence of fossil occurrences and from paleomagnetic reversal anomalies recorded by magnetic minerals in geologic sections. These sequence-ordered observations can be significantly supplemented by geochemical data (such as impact fallout) that are usually derived from thin rock layers representing an instant in geologic time. A temporally controlled stratigraphic framework (= chronostratigraphy) in the context of this study is an organizational system that represents the accumulation of peat and associated fluvial and lacustrine deposits during a specified time interval. Without a temporally based framework, there is little hope of producing accurate models of the formation of coal-bearing strata throughout a coal region. Such models or reconstructions of ancient environments are important in understanding the reasons for and thus in being able to evaluate and predict the quality, thickness, and distribution of coal deposits. This becomes particularly important for the consideration of coal at depth, which cannot be observed directly. 


\section{PROJECT SCOPE}

Ongoing research (Hartman, 1991a, b; Hartman and Kihm, 1991; Kihm and Hartman, 1991; Hartman and Kihm, 1992, 1995) is providing chronostratigraphic control for various portions of the Fort Union Group in the Fort Union Coal Region. To date, most of this research has focused on coal-bearing deposits of the middle and upper Paleocene. The research undertaken as part of the Makoshika study is focused on the transition from environments essentially devoid of peat accumulations to those in which peat is an important component of the paleoenvironment. Very frequently, this transition is lithostratigraphically marked by a laterally extensive lignite bed, such as the $\mathrm{Z}$ coal (or coal bed complex) in the western portion of the Fort Union Coal Region. This bed and its stratigraphic equivalents appear to represent a very nearly isochronous horizon, as indicated by paleontological and geochemical data. In the area of Glendive, the coal near the K/T boundary is referred to as the Contact lignite, in reference to its placement at the contact between the Hell Creek and Fort Union Formations (Figure 2). The K/T transition is, however, quite controversial and far from being understood precisely because of problems interpreting its stratigraphic setting.

The geologic section of the Makoshika State Park was chosen, in part, because the stratigraphy representing the $\mathrm{K} / \mathrm{T}$ transition is sufficiently complete in a number of sections to avoid the controversies often associated with the proper sequencing of fossil occurrences and paleomagnetic samples in less complete sequences. However, even the evidence for the completeness of the Makoshika section has been argued by some (Peter Sheehan, written communication, 1993).

The project determined the timing of the transition from non-coal-forming to coal-forming environments to produce a reference standard that incorporates palynomorph, vertebrate, invertebrate, and paleomagnetic temporal control. This multidisciplinary determination was undertaken primarily in Dawson County, Montana, in the greater area of Makoshika State Park near Glendive. The main study area includes the Hell Creek Formation and the Ludlow Member of the Fort Union Formation in T. 15 N., R. 55-56 E., as shown on the Glendive Quadrangle (1967; see Figures 3 and 4). All available published and unpublished information on the stratigraphy was critiqued for the purposes of this project (e.g., Butler, 1980; Hance, 1912; Sholes and others, 1989; Vuke-Foster and Colton, 1989; Daly, 1991). In addition, Susan Vukes of the Montana Bureau of Mines and Geology has provided J. Hartman with detailed geologic maps documenting numerous unpublished field observations, as well as prepublication copies of maps concerning the Glendive area. Original maps and field data of the Glendive area were provided by Raymond D. Butler for use in this project. Other researchers familiar with the study area have also had input into the project. These individuals include Peter $M$. Sheehan of the Milwaukee Public Museum, David E. Fastovsky of the University of Rhode Island, and Katherine Newton of Syracuse University. All available paleontological data bearing on the project was incorporated into the research plan. This includes localities known to the investigators through previous preliminary research. Local individuals, specifically Robert Hiatt, an optometrist in Glendive, and Mrs. Bernice Vashus of Glendive, provided fossils and general site locations for investigation. Other areas along the Cedar Creek Anticline (which also bears the exposures of Makoshika State Park) were examined in Montana and North Dakota to provide both local and regional context for the Makoshika observations. Unpublished fossils and stratigraphic data from the studies of Dean 
Pearson, of the Pioneer Trails Regional Museum, Bowman, North Dakota, were also incorporated into the project.

\section{SPECIFIC OBJECTIVES}

As mentioned above, the overall objective of the project is to better document the faunal transition from near the end the Cretaceous into the Paleocene. This task includes constructing a lithostratigraphic framework for all other observations, including geologic sections, to document the following:

- Stratigraphic placement of discovered fossil localities

- Lithic sampling for palynomorph studies

- Lithic sampling for paleomagnetic studies

- Stratigraphic correlation of all temporal data

All of these objectives were met and are discussed below.

A goal of this project was to document mammalian faunal turnover at the $\mathrm{K} / \mathrm{T}$ boundary in a new field area near Glendive, Montana (Figure 1), and to relate observed patterns to other biotic and abiotic changes across the boundary. In so doing, we hoped to investigate patterns of terrestrial vertebrate extinction, mammalian biochronology near the $\mathrm{K} / \mathrm{T}$ boundary, and the time of diversification of various eutherian groups, in particular the archaic ungulates of the Order Condylarthra. During field seasons in 1993 and 1994, activities were focused on accomplishing two major objectives:

- To find new localities in both the Hell Creek and Fort Union Formations and to screen wash matrix from these localities (Figure 2).

- To conduct detailed stratigraphic investigations in order to provide appropriate geologic context for paleontologic discoveries.

As a result of these efforts, four new fossil mammal localities were discovered, most notably the productive early Paleocene Hiatt South Locality from which at least 14 mammalian taxa have been recovered so far.

Another specific goal of this project was to document the occurrence of nonmarine mollusk species across the $\mathrm{K} / \mathrm{T}$ boundary. The record of nonmarine mollusks adjacent to the boundary is very meager. Although emphasis was given to the discovery of mollusks, only a few localities of significance were found, and these are from slightly younger Paleocene rocks from both north and south of the park. 


\section{METHODOLOGY}

\section{Geology}

Geologic studies in the Glendive area were conducted to provide a lithostratigraphic framework for all paleontologic and paleomagnetic observations (Figure 2). Thus geologic sections were made through strata in areas bearing mammalian and molluscan fossils and through intervals for which lithic samples were taken for palynologic and magnetic reversal studies. Geologic studies also included the geographic location of new and previously reported fossil localities (Figures 3 and 4). All fossil localities were cataloged as an L-number and maintained in a database. All observations were plotted on USGS 7.5-minute series topographic quadrangles. Some locations were determined using a global positioning system satellite receiver. Locality horizon elevation values were coordinated with section data to provide best-fit determinations. Geologic sections were measured by Timothy Kroeger (Bemidji State University and late of the Energy \& Environmental Research Center), Wesley Peck (Energy \& Environmental Research Center), and Joseph Hartman. Measured sections by Butler (1980 and unpublished data), Tschudy (1970 and unpublished data), K.R. Johnson (written communication, 1994), and Frye (1967) were updated and integrated into the current study (Figures 4 and 5). Sections were measured using a Jacob's staff, and lithic samples were described using a modified Munsell color chart (GSA, 1991). Stratigraphic location and section data were maintained in databases designed in $Q \& A^{\oplus}$, with sections referred to by $M$-numbers. Stratigraphic sections were produced using a modified version of the program STRATCOL described elsewhere (Hartman, 1992a). Figure 5 illustrates STRATCOL-derived sections generated from prescribed data formats specified in reports from a Q\&A database. The lithic symbols used in the displayed sections are given in Figure 6. The location of many of the stratigraphic sections measured for this study are illustrated by figures presented in this report. For example, Section M4769a, which includes the Muddy Tork Locality, is shown in Figures 7 and 8. These sections are related to the Witches Hat sections (M4769b and M7887a) in Figure 9, which in turn can be related to the paleomagnetic (M7887b) and pollen sections (M4770) southeast of Witches Hat (Figure 10). These sections include the K/T fern spike locality, which is specifically shown in Figure 11.

Lithic samples for palynomorph studies were taken in detailed stratigraphic sections across the interval suspected to contain the K/T boundary at sites in Makoshika State Park (e.g., Figure 12). These samples were processed and examined by Timothy Kroeger. Thus the local $K / T$ boundary was delimited on the basis of palynomorphs. Palynology studies also resulted in the identification of a fern spike in Section M4770 (Kroeger and others, 1993) (Figure 13a, b). This boundary interval is known to be effectively coincident, through the stratigraphic correlation of lignites, to an iridium anomaly observed near the Sand Creek Overlook, Makoshika State Park (Figure 14; D.E. Fastovsky, personal communication, 1995). Lithic samples for paleomagnetic study were taken by Steven Lund and Wesley Peck (Figure 15) and were analyzed by Steven Lund (Figure 16).

\section{Paleontology}

Fossil vertebrate localities were located by prospecting on foot and visually scanning the surface for fossils. All identifiable material from the surface was collected. The stratigraphic position of each locality bearing fossil mammal remains was determined relative to the $\mathrm{K} / \mathrm{T}$ 
boundary (Figure 2). Large amounts of sediment were processed from the most productive of the newly discovered localities, Hiatt South Locality (early Paleocene), in order to recover the mammalian fossils. This technique involved the underwater screening of sediment to remove the fine-grained mud matrix and examining the residual coarse-grained concentrate under microscopes to recover the fossils. Screen washing is an efficient means of obtaining large samples of fossils from poorly consolidated sediments, which disagregate during screening.

Transport of an adequate amount of sediment, typically measured in tons, to a source of moving water for screening can be difficult. Such was the case with the Hiatt and Hiatt South Localities since we could not access the locality by vehicle because of rugged topography within the park and placement of the locality several hundred feet above the nearest road (see Figures 17 and 18). At the Hiatt South Locality, therefore, we moved approximately $2200 \mathrm{~kg}$ of sediment using packhorses, with the aid of two local ranch hands, about one-half mile to where we could park the vehicles. From there we transported the sediment to the Yellowstone River for screening (Figure 19). At the Hiatt Locality, a tripod-pulley system (similar to that shown in Figure 8) was configured to pass $40-\mathrm{kg}$ bags of matrix from an upland surface down bluffs to creek level, some $60 \mathrm{~m}$ down and $200 \mathrm{~m}$ away.

No fossil mollusk specimens were discovered in Makoshika State Park through surface prospecting. Mollusks were discovered at mammalian sites through extensive surface picking, dryand wet-screen washing, and picking from bulk concentrate in the laboratory. This process, for example, produced three steinkerns at the Muddy Tork Locality and 28 steinkerns at the Hiatt South Locality. A few additional localities were discovered outside of the park through surface prospecting. All of these are of lower or middle Paleocene age.

\section{EXPLANATION AND SUMMARY OF FINDINGS}

\section{Geology Studies}

The geologic observations derived through the course of this study provided the basis for accurate placement of fossil localities relative to the $\mathrm{K} / \mathrm{T}$ boundary. All of the mammalian localities (except Vashus Locality) that occur in the area of the Glendive Quadrangle can be shown to be within $15 \mathrm{~m}$ of the boundary. The precise placement of the $\mathrm{K} / \mathrm{T}$ boundary was accomplished on the basis of palynomorphs at two locations, one in the area of the Hiatt and Hiatt South Localities (M4771) (Figure 17) and the other in the area southeast of Muddy Tork (M4770) (Figure 11). In addition, a fern spike was identified in the M4770 section corresponding to the 5-cm interval recognized as the boundary horizon (Kroeger and others, 1993) (Figure 13a, b). The $\mathrm{K} / \mathrm{T}$ boundary is in close subjacent position to a lignite, which has been referred to as the "Contact Coal" by Sholes and others (1989). This lignite is named in reference to its position as the horizon approximating the Hell Creek-Fort Union formational contact in this area. The Contact lignite can be traced throughout Makoshika State Park. At the southern end of the park, just below the Sand Creek Overlook (near the center of the south edge of sec. 28, T. 15 N., R. 56 E.) C.J. Orth recognized a dispersed iridium anomaly in association with the same lignite (D.E. Fastovsky, personal communication, 1995) (Figure 14). The extinction of diagnostic uppermost Cretaceous palynomorphs just below the fern spike and its association with an iridium event horizon provide confirmation of our placement of the $\mathrm{K} / \mathrm{T}$ boundary. 
The Uppermost Cretaceous Muddy Tork Locality (Figures 4 and 8) occurs in the uppermost part of the Hell Creek Formation near the base of a major channel sandstone system found near the park entrance on the south side of the road (see Figure 7 and Appendix I). This sandstone comprises a pyramid-shaped butte on top of this ridge and forms a landmark referred to locally as the Witches Hat (Figure 9). Thus the sandstone has been referred to in this report as the Witches Hat sandstone. To the east, the Q.V. Locality occurs at a nearly identical horizon near the base of a similar channel sandstone. The lower Paleocene Hiatt, Hiatt South, and Deer Crash mammalian localities occur essentially at the same stratigraphic level above the base of the Ludlow Member of the Fort Union Formation (see Appendix I). Each of these localities occurs at or very near the base of a thick sequence of channel sandstones (e.g., Figure 18).

The middle Paleocene School Well Locality (Figure 3), located north of Glendive, south of Lower Sevenmile Creek, is known from the middle of the Ludlow Member at the base of stacked sandstone channels. The locality can be placed precisely relative to the Poverty Flats lignite bed, which has been identified in a minor outcrop just east of the locality. The exact local placement of the School Well Locality relative to the Contact lignite is somewhat less certain, but is estimated to be about $60 \mathrm{~m}$. Uncertainty regarding this value exists as a result of assumptions about the dip of strata along this portion of the Cedar Creek Anticline and the inability to unequivocally identify the Contact lignite in its closest exposures to the east in the SW1/4 NW1/4 sec. 23, T. 17 N., R. 55 E., Stipek Quadrangle. Palynomorphs recovered from below the "Contact Coal" of Sholes and others (1989) have been identified by T.J. Kroeger as Paleocene in age, and not Cretaceous as might be expected (Hartman, unpublished data).

With the recognition of the $\mathrm{K} / \mathrm{T}$ boundary on the basis of palynomorphs, the polarity patterns of magnetic minerals through the Makoshika section were identified. Figures 15 and 16 illustrate the interpretation of the reversal stratigraphy. The black dots next to the polarity column illustrate the sampling control. As recognized globally (Berggren and others, in press), the $\mathrm{K} / \mathrm{T}$ boundary falls within reversed-polarity Chron 29r. The Makoshika data clearly indicate a reversed record for this interval. Thus the mammalian and molluscan localities in the lower part of the Ludiow Member of the Fort Union Formation lived near the end of the time represented by Chron 29r. The paleontologic age of the sediments bearing the mammalian fossils in the Ludlow have been interpreted to be Puercan, probably middle Puercan (Pu2?) in age. If this conclusion is correct, paleomagnetic data support a lower middle or upper lower Puercan age for the enclosing strata (see Prothero, in press). The Hell Creek Formation Lancian-age mammalian and molluscan fossils occur in Chron 30n. Thus, on the basis of the paleomagnetic section (Figure 15), these occurrences (e.g., Muddy Tork Locality), although within 10 to $15 \mathrm{~m}$ of the $\mathrm{K} / \mathrm{T}$ boundary, do not represent uppermost Cretaceous strata (Cretaceous strata within Chron 29r).

\section{Mammalian Studies}

Mammalian fossil localities are listed in Appendix I, and lists of taxa for each fauna are compiled in Appendix II. We have recovered fossil mammals from three horizons representing three different evolutionary faunas. In this study area, mammals of undoubted Paleocene age were found superposed over mammals of undoubted Late Cretaceous age, with no transitional assemblages of mixed type interposed (such assemblages are called "Bug Creek" -type assemblages after the famous Bug Creek Anthills locality; Sloan and Van Valen, 1965). We interpret this to 
mean that the transition between Cretaceous-type and Paleocene-type mammalian communities was geologically rapid.

Fossil mammals from the Upper Cretaceous Hell Creek Formation (Muddy Tork Fauna) are indicative of the Lancian Land Mammal Age (Lillegraven and McKenna, 1986). Lancian faunas are recognized by their similarity to fauna from the type Lance Formation, Wyoming (Clemens 1964, 1966, and 1973; Fox, 1974; Krause, 1992), and are known from discoveries in Colorado (Carpenter, 1979), Alberta (Lillegraven, 1969), elsewhere in Montana (Sloan and Van Valen, 1965; Archibald, 1982), New Mexico (Flynn, 1986), and Saskatchewan (Fox, 1989; Storer, 1991). The fauna present in the Muddy Tork Fauna includes stagodontid and pediomyid marsupial taxa that make unique appearances in Lancian time (Lillegraven and McKenna, 1986). The multituberculate Meniscoessus robustus and the peradectid marsupial Turgidodon rhaister-both present at Muddy Tork-last appear in Lancian time (Lillegraven and McKenna, 1986), preciuding a younger age. No "Paleocene aspect" taxa are known from the Muddy Tork Fauna, making this fauna of undoubted Late Cretaceous age.

It has been suggested that latitudinal differences in faunal composition among Lancian sites-with greater abundance and diversity of eutherian mammals at northern latitudes-may reflect an initial migration from Asia and adaptive radiation of eutherian taxa (Lillegraven, 1969; Archibald, 1982; Fox, 1989). While this suggestion is controversial, the observation remains valid that eutherians seem to have been more diverse at higher latitudes during the Lancian. Lack of eutherian mammals in the Muddy Tork Fauna may be a sampling artifact, but tentatively supports placement of this fauna in a more southerly biogeographic realm with other localities from Montana to New Mexico. The multituberculate Meniscoessus robustus is common at Muddy Tork, while the abundance of this taxon declines further north (Lillegraven, 1969; Fox, 1989; Storer, 1991).

The Hiatt Locality Fauna (including material from the Hiatt Locality, Hiatt South Locality, and the Deer Crash Locality all from the lower part of the Ludlow Member of the Fort Union Formation) is the most intriguing of these three faunas because of the rarity of early Paleocene mammals, because of the many problems associated with the biochronology of the early Paleocene, and because of the importance of the early Paleocene in mammalian history. The fauna is similar to that recovered from other northern latitude, early Paleocene sites of the Puercan Land Mammal Age, notably Rav W-1 and Purgatory Hill. Rav W-1 may be early Puercan (Johnston and Fox, 1984) or middle Puercan (Archibald and others, 1987) in age, whereas Purgatory Hill probably represents the late Puercan (Van Valen and Sloan, 1965; Van Valen, 1978; Archibald and others, 1987). Numerous workers, however, have argued that middle and late Puercan cannot be distinguished outside of their type area in the San Juan Basin (e.g., Archibald and others, 1987). The Hiatt Locality Fauna and Rav W-1 share a number of taxa, including the multituberculate Neoplagiaulax kremnus (or a closely related species), as well as taxa of arctocyonid condylarths (Baioconodon, Loxolophus schizophrenus, Oxyclaenus?, and Carcinodon?). The Hiatt Locality Fauna also includes some very primitive taxa, such as a species of Loxolophus, which may indicate that this genus originated at the base of condylarth phylogeny. The species of Eoconodon present-a condylarth believed to be at the base of the whale lineage-may be conspecific with a form from Purgatory Hill, and one periptychid condylarth present, Tinuviel eurydice, is known elsewhere only from Purgatory Hill (Van Valen, 1978). Finally, the primitive taeniodont Onychodectes has been previously reported only from New Mexico and Utah (Schoch, 1986), 
making our find of Onychodectes a significant geographic range extension for the genus. Given the diverse assemblage of condylarths and some negative evidence-the absence of the multituberculate Taeniolabis taoensis, the appearance of which marks the base of the late Puercan-we provisionally assign the Hiatt Locality Fauna to the middle Puercan (?Pu2; Archibald and others, 1987).

Present evidence suggests a Torrejonian age for the School Well Locality. The plesiadapiform (?primate) Paromomys makes its first appearance in the Torrejonian (Archibald and others, 1987). The mioclaenid condylarth Litaletes may occur as early as the Puercan (Johnston and Fox, 1984), but the species present is close to and perhaps conspecific with the Torrejonian Litaletes mantiensis (Gazin, 1939, 1941; Rigby, 1980). More complete material is needed to tell whether the large periptychid condylarth present is referable to the Torrejonian Periptychus carinidens, the Puercan Periptychus (Carsioptychus) coarctatus, or to a new species. The multituberculate Ptilodus montanus is also known from late Torrejonian localities in the Crazy Mountain Basin (Krause, 1982). Although this species is not known from the early Torrejonian, this may be an artifact of sampling. More material is needed before it will be possible to determine more precisely the age of the School Well Locality.

\section{Molluscan Studies}

The nonmarine molluscan fauna known from in and adjacent to Makoshika State Park is presently incapable of refining the molluscan interpretation of the K/T boundary signature. As noted, all specimens are preserved as steinkerns, which severely limits one's ability to identify species and determine species ranges. Maybe as few as four gastropod taxa are represented in the fauna, including species of Viviparus, Campeloma, Lioplacodes, the taxon New Genus A limneaformis (see Hartman, 1984), and three bivalve taxa, including a large unsculptured unionid; a few relatively small, elongate unionid steinkerns; and one steinkern of a pisidiid. The species of snail present in the lower part of the Ludlow in Makoshika State Park are sufficiently distinctive to indicate that they are presently unknown from the Cretaceous and thus potentially good indicators of Paleocene strata. New Genus A limneaformis is known to range across the $\mathrm{K} / \mathrm{T}$ boundary and thus is of little value in these discussions. Although of limited systematic or biostratigraphic value, this depauperate fauna represents the limited species diversity typically found at many localities in the lowermost Paleocene in North America.

\section{Williston Basin Correlations}

The occurrence of numerous lignite beds in the Fort Union Formation (or Group) in the Williston Basin is well known. Many beds have been mapped in Montana and North Dakota in the lower part of the formation (Sholes and others, 1989; Hares, 1928). The age relations of the strata bearing lignites, however, have been considered only in general terms prior to recent research. This project has facilitated a reevaluation of the chronostratigraphy of coal-bearing strata in North Dakota. Figure 20 illustrates a summary determination of the age relations of lithostratigraphic units in the North Dakota portion of the Williston Basin. This figure presents for the first time a reversal stratigraphic framework for these units. A paleomagnetic framework, added to a radiometric time scale and relative mammalian biochrons, provides numerous opportunities to refine the history of coal formation in the Fort Union Coal Region. 
In North Dakota, the $\mathrm{K} / \mathrm{T}$ boundary is relatively well known by the lowest persistent lignite or carbonaceous bed above the highest dinosaur fossils. Exceptions occur where nonlignite environments persist through this section (see for examples Murphy and others, 1995). In southeastern North Dakota, in exposures along tributaries of the Missouri River; in southwestern North Dakota, in exposures along tributaries of the Little Missouri River; and in the Glendive area in easternmost Montana, the $\mathrm{K} / \mathrm{T}$ boundary has been recognized on the basis of palynomorphs. Recognition of the formational contact between the Hell Creek and Fort Union Formations, however, has varied in interpretation (see for example, Lerbekmo and Coulter, 1984). However, the relative placement of the K/T boundary within Chron 29r varies only a few meters in sections as distantly separated as Huff (south of Bismarck), North Dakota, and Glendive, Montana. Lignites occurring in the underlying Hell Creek Formation are few, thin, and of limited value economically or for stratigraphic correlation studies. The quantity and quality of lignites vary in the overlying Fort Union Formation. Paleoenvironmental settings through the lower and middle Paleocene were undoubtedly influenced by the movements of the Cannonball Sea. Possible age relations of the tongues of the Cannonball Formation are presented in Figure 20. Numerous and relatively thick lignites do not appear to form until the middle Paleocene, at least in the drainages of the Little Missouri River, where these strata are well exposed. This section may temporally correlate to the strata about and above the Poverty Flats lignite (Figure 2), on the basis of the occurrence of Torrejonian-age mammals north of Glendive at the School Well Locality.

\section{STATEMENT OF RESULTS}

Fossil evidence tied to radiometric and paleomagnetic chronologies provides the basis for methodologies to refine the precise chronostratigraphic correlation of lignite beds. This ability permits a better interpretation of coal-forming environments over a broad region, such as the northern Great Plains. More realistic temporally controlled models for paleoenvironmental conditions will provide the potential for improved coal quality assessment in regional appraisals of available coal resources.

This project determined the timing of the transition from non-coal-forming to coal-forming environments to produce a reference standard that incorporates palynomorph, vertebrate, invertebrate, and paleomagnetic temporal control. This multidisciplinary determination was undertaken primarily in Dawson County, Montana, in the greater area of Makoshika State Park near Glendive. With the recognition of the $\mathrm{K} / \mathrm{T}$ boundary on the basis of palynomorphs, the stratigraphy of polarity signals through the Makoshika section could be determined. The K/T boundary in the Makoshika section falls within reversed-polarity Chron 29r. The Makoshika data clearly indicate a reversed record for this interval. Thus the mammalian and molluscan localities in the lower part of the Ludlow Member of the Fort Union Formation lived near the end of the time represented by Chron 29r. The paleontologic age of the sediments bearing the mammalian fossils in the Ludlow have been interpreted to be Puercan, probably middle Puercan (Pu2?) in age. If this conclusion is correct, paleomagnetic data support a lower middle or upper lower Puercan age for the enclosing strata. The Hell Creek Formation Lancian-age mammalian and molluscan fossils occur in Chron 30n. On the basis of the paleomagnetic section, these occurrences (e.g., Muddy Tork Locality), although within 10 to $15 \mathrm{~m}$ of the $\mathrm{K} / \mathrm{T}$ boundary, do not represent faunas at the very end of the Cretaceous (i.e., Cretaceous strata within Chron 29r). 
The succession of fossil mammals in Makoshika State Park and surrounding areas spans the Late Cretaceous and early and middle Paleocene. The Muddy Tork Fauna (Late Cretaceous) is typical Lancian and includes no Paleocene-aspect taxa. The Hiatt Locality Fauna (early Paleocene) can be placed into the Puercan (probably the Pu2 interval zone) on the basis of its diverse condylarth fauna. The School Well Fauna (middle Paleocene) places the top of the Ludlow member of the Fort Union Formation into the Torrejonian Land Mammal Age. In the study area, localities of Late Cretaceous age are separated from those of early Paleocene age by about $20 \mathrm{~m}$ of intervening sediment containing no unconformity.

Despite intensive search, no Bug Creek-type assemblages, i.e., of mixed Cretaceous and Paleocene aspect, have been found in Makoshika State Park. Paleocene channels appear not to have eroded into Cretaceous sediment at our study locations, perhaps accounting for the lack of Bugcreekian sites. Thus our work provides no support for recognition of a Bugcreekian time interval. The presence of a diverse assemblage of condylarths just $11 \mathrm{~m}$ above the $\mathrm{K} / \mathrm{T}$ boundary at the horizon of the Hiatt Locality suggests that the adaptive radiation of this group was extremely rapid, as it probably occurred only after the dinosaur extinction.

\section{BIBLIOGRAPHY}

Archibald, J. D., 1982, A study of Mammalia and geology across the Cretaceous-Tertiary boundary in Garfield County, Montana: University of California Publications in Geological Sciences 122, p. 1-286.

Archibald, J. D., Gingerich, P. D., Lindsay, E. H., Clemens, W. A., Krause, D. W., and Rose, K. D., 1987, First North American Land Mammal Ages of the Cenozoic Era, in Cenozoic Mammals of North America, ed. Woodbourne, M. O., p. 24-76: Berkeley, University of California Press, 336 p.

Averitt, P., 1975, Coal resources of the United States, January 1, 1974: U.S. Geological Survey, Bulletin 1412, 131 p.

Beggren, W.A., Kent, D.V., Swisher, C.C., III, Aubry, M.-P., in press, A revised Cenozoic geochronology and chronostratigraphy, in Berggren, W.A., Kent, D.V., and Hardenbol, J., eds., Geochronology, time scales and global stratigraphic correlations: A unified temporal framework for an historical geology: Society of Economic Paleontologists and Mineralogists Special Publication 54.

Butler, R.D., 1980, Stratigraphy, sedimentology, and depositional environments of the Hell Creek Formation (Late Cretaceous) and adjacent strata, Glendive area, Montana [Ph.D. thesis]: Grand Forks, University of North Dakota, 398 p.

Carpenter, K., 1979, Vertebrate fauna of the Laramie Formation (Maestrichtian), Weld County, Colorado: Contributions to Geology, University of Wyoming, v. 17, p. 37-49.

Clayton, L., 1980, Geologic map of North Dakota, 1:500,000: North Dakota Geological Survey, 1 sheet. 
Clemens, W. A., 1964, Fossil mammals of the type Lance Formation, Wyoming. part I. introduction and Multituberculata: University of California Publications in Geological Sciences 48, p. 1-105.

Clemens, W. A., 1966, Fossil mammals of the type Lance Formation, Wyoming. part II. Marsupialia: University of California Publications in Geological Sciences 62, p. 1-122.

Clemens, W. A., 1973, Fossil mammals of the type Lance Formation, Wyoming. part III. Eutheria and summary: University of California Publications in Geological Sciences 94, p. 1-102.

Clyde, W.C., Stamatakos, J., and Gingerich, P.D., 1994, Chronology of the Wasatchian LandMammal Age (Early Eocene): Magnetostratigraphic results from the McCullough Peaks Section, northern Bighorn Basin, Wyoming: Journal of Geology, v. 102, p. 367-377.

Daly, D.J., 1991, The stratigraphy and depositional environments of the Fox Hills Formation, Bowman County, North Dakota, in Sixth International Williston Basin Symposium, Proceedings (Regina, Saskatchewan, Canada): Saskatchewan Geological Society, Special Publication 11, p. 193-205.

Flynn, L. J., 1986, Late Cretaceous mammal horizons from the San Juan Basin, New Mexico: American Museum Novitates 2845, p. 1-30.

Fox, R. C., 1974, Deltatheroides-like mammals from the Upper Cretaceous of North America. Nature, v. 249, p. 392.

Fox, R. C., 1989, The Wounded Knee local fauna and mammalian evolution near the Cretaceous-Tertiary boundary, Saskatchewan, Canada: Palaeontographica, v. 208, p. 11-59.

Fox, S.K., Jr., and Olsson, R.K., 1969, Danian planktonic foraminifera from the Cannonball Formation in North Dakota: Journal of Paleontology, v. 43, no. 6, p. 1397-1404.

Frye, C.I., 1967, The Hell Creek Formation in North Dakota [Ph.D. thesis]: Grand Forks, University of North Dakota, 411 p., 8 pls.

Gazin, C. L., 1939, A further contribution to the Dragon Paleocene fauna of central Utah. Journal of the Washington Academy of Sciences, v. 29, p. 273-286.

Gazin, C. L., 1941, The mammalian faunas of the Paleocene of central Utah, with notes on the geology: United State National Museum, Proceedings, v. 91, p. 1-53.

GSA (Geological Society of America), 1991, Rock Color Chart: Boulder, Geological Society of America.

Gunnell, G.R., Bartels, W.S., and Gingerich, P.D., 1993, Paleocene-Eocene boundary in continental North America: Biostratigraphy and geochronology, northern Bighorn Basin, Wyoming: New Mexico Museum of Natural History and Science, Bulletin 2, p. 137-144. 
Hance, J.H., 1912, The Glendive lignite field, Dawson County, Montana: U.S. Geological Survey, Bulletin 471-D, p. 271-283.

Hares, C.J., 1928, Geology and lignite resources of the Marmarth field, southwestern North Dakota: U.S. Geological Survey, Bulletin, v. 775, 110 p., 14 pls.

Hartman, J.H., 1984, Systematics, biostratigraphy, and biogeography of latest Cretaceous and early Tertiary Viviparidae (Mollusca, Gastropoda) of southern Saskatchewan, western North Dakota, eastern Montana, and northern Wyoming [Ph.D. Thesis]: Minneapolis, University of Minnesota, 928 p., 19 pls.

Hartman, J.H., 1991a, Coal science: Earth resource evaluation and management: Semiannual technical report for the period January through June 1991, DE-FC21-86MC10637: EERC Publication.

Hartman, J.H., 1991b, The stratigraphic distribution of nonmarine Mollusca across the Cretaceous-Tertiary boundary in the northern Great Plains: Geological Society of America Annual Meeting (invited participant to the theme session on the Nonmarine Fossil Record at the Cretaceous-Tertiary Boundary, October 21-24, 1991), v. 23, no. 5, p. A359.

Hartman, J.H., 1992a, Coal science: Earth resource evaluation and management: Semiannual technical report for the period July through December 1991, DE-FC21-86MC10637: EERC publication.

Hartman, J.H., 1992b, Coal science: Earth resource evaluation and management: Semiannual technical report for the period January through June 1992, DE-FC21-86MC10637: EERC Publication.

Harman, J.H., and Butler, R.D., 1995, Extinction and recovery of nonmarine molluscan assemblages in the Late Cretaceous and early Tertiary (Symposium on Patterns and Processes of Mass Extinctions: An Integrated Approach): Geological Society of America (Rocky Mountain Section), Abstracts with Programs, v. 27, no. 4, p. 13.

Hartman, J.H., and Kihm, A.J., 1992, Chronostratigraphy of Paleocene strata in the Williston Basin, p. 52-75, in Finkelman, R.B., Tewalt, S.J., and Daly, D.J., eds., Geology and utilization of Fort Union lignites: Reston, Virginia, Environmental and Coal Associates, $359 \mathrm{p}$.

Hartman, J.H., and Kihm, A.J., 1991, Stratigraphic distribution of Titanoides (Mammalia: Pantodonta) in the Fort Union Group (Paleocene) of North Dakota: Sixth International Williston Basin Symposium, Regina, Saskatchewan, Canada, p. 207-215.

Hartman, J.H., and Kihm, A.J., 1995, Age of Meek and Hayden's Fort Union Group (Paleocene), upper Missouri River, North Dakota-Montana: Seventh International Williston Basin Symposium, 1995 Guidebook, Billings, Montana, p. 417-428. 
Hartman, J.H., Roth, B., and Kihm, A.J., 1993, Stratigraphy and paleontology of a diverse assemblage of nonmarine mollusks and associated mammals from the Sentinel Butte Formation of North Dakota: North Dakota Academy of Science, Proceedings, v. 47, p. 50.

Hickey, L.J., 1977, Stratigraphy and paleobotany of the Golden Valley Formation (Early Tertiary) of western North Dakota: Geological Society of America, Memoir 150, 183 p, 55 pls.

Johnston, P. A., and Fox, R. C., 1984, Paleocene and Late Cretaceous mammals from Saskatchewan, Canada: Palaeontographica, v. 186, p. 163-222.

Kihm, A.J., and Hartman, J.H., 1990, Chronostratigraphic implications of the mammal and nonmarine mollusk record of the Paleocene Fort Union Group in North Dakota: North Dakota Academy of Science (82nd Annual Meeting), Proceedings, v. 44, p. 70.

Kihm, A.J., and Hartman, J.H., 1991, The age of the Sentinel Butte Formation, North Dakota: Society of Vertebrate Paleontology (Annual Meeting, October 24-26, 1991), Journal of Vertebrate Paleontology, v. 11, supplement to no. 3, p. 40a.

Kihm, A.J., Hartman, J.H., and Krause, D.W., 1993, The Red Spring local mammal fauna, Sentinel Butte Formation (Paleocene), Mercer County, North Dakota: Journal of Vertebrate Paleontology (Society of Vertebrate Paleontology, 53rd Annual Meeting, Albuquerque), v. 13, supplement to no. 3, p. 44 a.

Krause, D. W., 1982, Evolutionary history and paleobiology of early Cenozoic Multituberculata (Mammalia), with emphasis on the family Ptilodontidae [Ph.D. Dissertation]: Ann Arbor, University of Michigan, $575 \mathrm{p}$.

Krause, D. W., 1992, Clemensodon megaloba, a new genus and species of Multituberculata (Mammalia) from the Upper Cretaceous type Lance Formation, Powder River Basin, Wyoming: PaleoBios, v. 14, p. 1-8.

Krause, D.W., Wunderlich, R., Hartman, J.H., and Kroeger, T.J., 1992, Latest Cretaceous and early Paleocene mammals from Makoshika State Park, Williston Basin, eastern Montana: Journal of Vertebrate Paleontology, Abstracts of Papers, 52nd Annual Meeting, Royal Ontario Museum (Toronto), v. 12, supplement to no. 3, p. 38a.

Kroeger, T.J., Hartman, J.H., and Peck, W.D., 1993, Provisional palynological recognition of the fern spike at the Cretaceous-Tertiary Boundary, Makoshika State Park, Dawson County, Montana: North Dakota Academy of Science (1993 Annual Meeting), v. 47, p. 48.

Lerbekmo, J.F., and Coulter, K.C., 1985, Magnetostratigraphic and biostratigraphic correlations of Late Cretaceous and Early Paleocene strata between Alberta and North Dakota: Canadian Society of Petroleum Geologists, Memoir 9, p. 313-317.

Lillegraven, J. A., 1969, Latest Cretaceous mammals of upper part of Edmonton Formation of Alberta, Canada, and review of marsupial-placental dichotomy in mammalian evolution: The University of Kansas Paleontological Contributions 50, p. 1-122. 
Lillegraven, J. A., and McKenna, M. C., 1986, Fossil mammals from the "Mesaverde" Formation (Late Cretaceous, Judithian) of the Bighorn and Wind River Basins, Wyoming, with definitions of Late Cretaceous North American Land-Mammal "Ages": American Museum Novitates 2840 , p. $1-68$.

Lund, S.P., 1995 (written communication), Magnetostratigraphy of interfingering Upper Cretaceous and Paleocene marine and continental strata of the Williston Basin, North Dakota (unpublished manuscript).

Lund, S.P., and Hartman, J.H., in preparation, Paleomagnetic stratigraphy of the CretaceousTertiary transition in south-central North Dakota and easternmost Montana.

Montana Department of Fish, Wildlife and Parks, 1985, Makoshika State Park Road Guide: Great Falls, Montana Department of Fish, Wildlife and Parks, 47 p.

Murphy, E.C., Nichols, D.J., Hoganson, J.W., and Forsman, N.F., 1995, The Cretaceous/ Tertiary boundary in south-central North Dakota: North Dakota Geological Survey, Report of Investigation $98,73 \mathrm{p}$.

Prothero, D.R., in press, Geochronology and magnetostratigraphy of Paleocene North American Land Mammal "Ages": An update, in Berggren, W.A., Kent, D.V., and Hardenbol, J., eds., Geochronology, time scales and global stratigraphic correlations: A unified temporal framework for an historical geology: Society of Economic Paleontologists and Mineralogists Special Publication 54.

Rigby, J. K., Jr., 1980, Swain Quarry of the Fort Union Formation, middle Paleocene (Torrejonian), Carbon County, Wyoming: geologic setting and mammalian fauna. Evolutionary Monographs, v. 3, p. 1-178.

Schoch, R.M., 1986, Systematics, functional morphology and macroevolution of the extinct mammalian Order Taeniodonta: Yale University, Peabody Museum of Natural History, Bulliton 42, $307 \mathrm{p}$.

Sholes, M.A., Vuke-Foster, S.M., and Derkey, P.D., 1989, Coal stratigraphy and correlation in the Glendive 30x60-minute quadrangle, eastern Montana and adjacent North Dakota: Montana Bureau of Mines and Geology, Geologic Map 49, 4 sheets.

Sloan, R. E., and Van Valen, L., 1965, Cretaceous mammals from Montana: Science, v. 148, p. 220-227.

Storer, J. E., 1991, The mammals of the Gryde Local Fauna, Frenchman Formation (Maastrichtian: Lancian), Saskatchewan: Journal of Vertebrate Paleontology, v. 11, p. 350-369.

Tschudy, R.H., 1970, Palynology of the Cretaceous-Tertiary boundary in the northern Rocky Mountain and Mississippian embayment regions: Geological Society of America, Special Paper 127, p. 65-111. 
Van Valen, L. M., 1978, The beginning of the age of mammals: Evolutionary Theory, v. 4, p. 45-80.

Van Valen, L., and Sloan, R. E., 1965, The earliest primates: Science, v. 150, p. 743-745.

Vuke-Foster, S.M., and Colton, R.B., 1989, Coal and clinker outcrop map of the Glendive 30x60minute quadrangle, eastern Montana and adjacent North Dakota: Montana Bureau of Mines and Geology, Geologic Map 49, sheet 1.

Warwick, P.D., Murphy, E.C., and Obradovich, J.D., 1995, Parasequences in the Paleocene Ludlow and Cannonball Members of the Fort Union Formation, Williston Basin, North Dakota: Geological Society of America (Rocky Mountain Section), Abstracts with Programs, v. 27, no. 4, p. 60 . 


\section{FIGURE CAPTIONS}

Figure 1. Williston Basin Glendive area studies, Dawson County, Montana. The bedrock geology displayed on this map was derived from Clayton (1980) and unpublished data provided by S.M. Vuke of the Montana Bureau of Mines and Geology and Foster Sawyer of the South Dakota Geological Survey (see Hartman and Kihm, 1995).

Figure 2. Glendive area fossil stratigraphy. This figure represents the general stratigraphy of lithostratigraphic units in the Glendive study area. Basic unit data were derived from Butler (1980), Sholes and others (1989), S.M. Vuke (written communications, 1994, 1995), Daly (1991), and Hartman (unpublished observations). The placement of fossil localities and the fern spike were determined as part of the present study (see also Kroeger and others, 1993). All mammalian localities are referred to by name (see Appendix I) and all molluscan localities are referred to by number. Note that mollusks are also known from the School Well, Hiatt South, Deer Crash, and Muddy Tork Localities.

Figure 3. Glendive area - Makoshika State Park fossil localities, Dawson County, Montana. General location map of mammalian and molluscan Upper Cretaceous and Paleocene fossil localities. All mammalian localities are referred to by name (see Appendix I), and all molluscan localities are referred to by number. Note that mollusks are also known from the School Well, Hiatt South, Deer Crash, and Muddy Tork Localities. Mollusks were also discovered, collected, or previously known to the west on the Poverty Flat West Quadrangle (L4990, L6423) and Olson Coulee South (L6395, L6396, L6416, L6417) and to the south on the Upper Magpie Reservoir Quadrangle (L6432, L6433) and Hoyt Quadrangle (L952, L958, L1099, L1100, L1356, L5413, L6206, L6207, L6332, L6333).

Figure 4. Makoshika State Park - Muddy Tork and Hiatt area fossil localities. Base map derived from USGS Glendive Quadrangle (1967). Geology modified from Sholes and others, 1989 , in fossil locality study areas. M-numbered lines are measured sections. Sections M3715, M3723, and M3724 are from Butler (1980). Section M156, which is placed approximately based on section thickness and available relative relief, is from Frye (1967). All other sections were measured through the course of present Glendive area studies. Other measured sections not displayed in this figure include M6723 (similar track as M7877b in the fern spike section) and M2114 and M2271, which represent sections for preliminary palynomorph age determinations in the area of the Hiatt Locality.

Figure 5. Stratigraphy of fossil localities in Sec. 1, T. 15 N., R. 55 E., Makoshika State Park, Montana. The measured sections illustrated in this figure are located on opposite sides of Cains Coulee, and document the stratigraphic position of the Muddy Tork, Hiatt, and Hiatt South mammalian localities. The first and last, along with localities L6260 and L6425, also contain a few poorly preserved mollusks. Also shown are $\mathrm{K} / \mathrm{T}$ boundary and fern spike, which are illustrated in greater detail in 
succeeding figures. See Figure 6 for interpretation of lithic symbols and the Appendix for measured section data.

Figure 6. Lithic symbols for measured sections. This figure illustrates the lithic interpretation of the symbols used in stratigraphic sections in this report.

Figure 7. Muddy Tork Locality, Makoshika State Park, Montana. This figure illustrates the location of measured Section M4769a, the Muddy Tork Locality, and the westward extent from the Witches Hat Sandstone (see Appendix for measured section data). The prominent conical feature representing Witches Hat occurs just to the east of this photograph (see Figure 9).

Figure 8. Muddy Tork Locality, Makoshika State Park, Montana. This figure shows the precise location of the Muddy Tork fossil locality. The foreground channelform sandstones are of the Witches Hat Sandstone. The tripod in this view was tethered to the south with ropes to permit a tripod trolley (pulley, rope, and matrix bag) system to be employed to transport bulk matrix directly to the road below. A similar system was first used at the Hiatt Locality.

Figure 9. Witches Hat sections, Makoshika State Park, Montana. This view is along the same east-west ridge as shown in Figure 8. Witches Hat consists of a sequence of channel sandstones. Sections M4769b and M7887a can be composited to form a continuous sequence from the road in the north along Cains Coulee (see Appendix for measured section data). Section M4769b was measured from the base of a substantial channel scour on the north face of the butte to the end of the white line illustrating the lowest part of the section in this view. The fern spike section (M7887b) was taken on the butte to the right of Witches Hat (Figure 10).

Figure 10. Paleomagnetic, fern spike, and K/T boundary sections, Makoshika State Park, Montana. Section M7887b was measured southeast of Witches Hat from the bottom of the coulee (out of view in this photograph). The locations of the Contact lignite and fern spike are shown (see Appendix for measured section data).

Figure 11. Fern Spike Locality, K/T boundary interval, Makoshika State Park, Montana. The fern spike pit is shown on the steep, south-facing slope of this butte. The Contact lignite and approximate location of unionid locality $L 6260$ can be seen across the saddle. Sections M7921 and M7922 were taken on the east end of this butte through the $\mathrm{K} / \mathrm{T}$ boundary interval.

Figure 12. The placement of the $K / T$ boundary in Makoshika State Park, Montana. This figure illustrates Section M4770 and details the lithic sampling used in the recognition of the $\mathrm{K} / \mathrm{T}$ boundary on the basis of palynomorphs. The section was measured and sampled by W.D. Peck and J.H. Hartman, and the palynomorphs were identified and interpreted by T.J. Kroeger (see Appendix for measured section data). The fern spike was reported by Kroeger and others (1993). Units 1-3 are clayey siltstones, Unit 4 is a lignite, and Unit 5 is a siltstone. Divisions within units represent sampling intervals. 
Figure 13a. K/T boundary fern spike, Makoshika State Park, Montana. This figure (Kroeger and others, 1993) illustrates in detail the recognition of the fern spike in Section M4770 shown in Figure 12.

Figure 13b. K/T boundary interval pollen diagram. The increase in relative percentage of the fern pollen and concomitant decrease in other taxa are shown in this figure (Kroeger and others, 1993).

Figure 14. Sand Creek Overlook sections, Makoshika State Park, Montana. A dispersed iridium anomaly was reported from the interval of the Contact lignite below the Sand Creek Overlook at the south end of Makoshika State Park (D.E. Fastovsky, personal communication, 1995). The distinctive "pink" layer, very near the K/T boundary, was found elsewhere in the park, occasionally associated with silcretes (east of Q.V. Locality). Section M8282 is a boundary section measured by Cathryn Newton (Syracuse University) and others. Section M8283 was sampled for palynomorph studies through their section pit (see Appendix for measured section data).

Figure 15. Paleomagnetic stratigraphy - fern spike section, Makoshika State Park, Montana. Paleomagnetic samples were collected through the interval of the $\mathrm{K} / \mathrm{T}$ boundary southeast of Witches Hat. The numbered samples are shown by black dots next to the polarity section. The radiometric dates for the magnetochron boundaries are from Berggren and others (1995).

Figure 16. Paleomagnetic data for Section M7887b, Makoshika State Park, Montana. This figure represents the basic paleomagnetic data for the samples shown in stratigraphic section in Figure 15. The samples were analyzed by S.P. Lund (written communication, 1995).

Figure 17. Hiatt and Hiatt South Localities, Makoshika State Park, Montana. This view is from the top of the butte bearing Section M7887b and overlooks the rifle range to the tributary of Cains Coulee. The Hiatt and Hiatt South mammalian localities occur on the north side of the side coulee in the basal light-colored units of a sequence of channelform sandstones. Section M4376 represents the major section through this stratal interval. Sections M4771 and M8279 place the localities relative to the Contact lignite and $\mathrm{K} / \mathrm{T}$ boundary. The $\mathrm{K} / \mathrm{T}$ boundary was recognized on the basis of palynomorphs in Section M4771.

Figure 18. Hiatt South Locality, Makoshika State Park, Montana. Of the two mammalian localities in this area, the Hiatt South Locality is the best documented. The Hiatt South Quarry can be seen in this view, along with the trend of Section M8279. The $\mathrm{K} / \mathrm{T}$ boundary and Hell Creek-Fort Union (Ludlow Member) formational contact occurs below the view shown here. Bulk matrix sampled from this locality was taken to road access by pack horses.

Figure 19. Bulk sediment screen washing, Yellowstone River, Glendive, Montana. Bulk sediment samples are hauled to a "washing" site, preferably a flowing body of water with a firm substrate, so that the sediment can be wet-screened. The "concentrate" is 
removed and allowed to dry. The processed sediment will be processed in the laboratory for small to minute fossils.

Figure 20. Chronostratigraphy of North Dakota strata. This figure represents the first detailed comparison of uppermost Cretaceous, Paleocene, and Lower Eocene nonmarine strata of North Dakota with the global paleomagnetic reversal record. Previous versions (e.g., Hartman and Kihm, 1995) have been modified with unpublished magnetic, radiometric, and paleontologic data. The radiometric dates on the boundaries of magnetochrons is from Berggren and others (in press). Interpretation of the correlation of mammalian ages with magnetochrons was derived from Clyde and others (1994), Gunnell and others (1993), and Prothero (in press). Other lowermost Paleocene paleomagnetic data were provided by Lund (written communication, 1995; Lund and Hartman, in preparation). Other radiometric dates were provided by D.A. Pearson (personal communication, 1995) and reported by Warwick and others (1995). Planktic foraminifera data of Fox and Olsson (1969) and correlation with radiometric dates were interpreted by L.S. Collins (written communication, 1994, 1995). Litho- and chronostratigraphic placement of mammalian localities was modified from Kihm and Hartman (1990, 1991), Hartman and Kihm (1991, 1992, 1995), Hartman and others (1993), and Kihm and others (1993). Other mammalian data on new localities were provided by J.P. Hunter and D.A. Pearson (personal communication, 1994, 1995). Interpretation of the stratigraphy of the transgressive and regressive histories of the tongues of the Cannonball Formation was modified from Hartman and Butler (1995; and unpublished data). Symbols: The dotted line, representing the contact between the Sentinel Butte and Golden Valley Formations is temporally uncontrolled. The Bear Den Member of the Golden Valley Formation was interpreted to be Clarkforkian by Hickey (1977) on the basis of plants, but the age of the uppermost part of the Sentinel Butte Formation is unknown. White dots with black rims indicate localities that have been placed in the diagram solely on the basis of their stratigraphic position. The possible age range of PTM V86005 is shown with a vertical line through a black dot. The Brown Ranch localities, which occur in a single lithosome, are shown as one black dot. The dot is placed on the diagram on the basis of the localities' stratigraphic position, but the few mammalian fossils from this locality also suggest a Torrejonian age. 


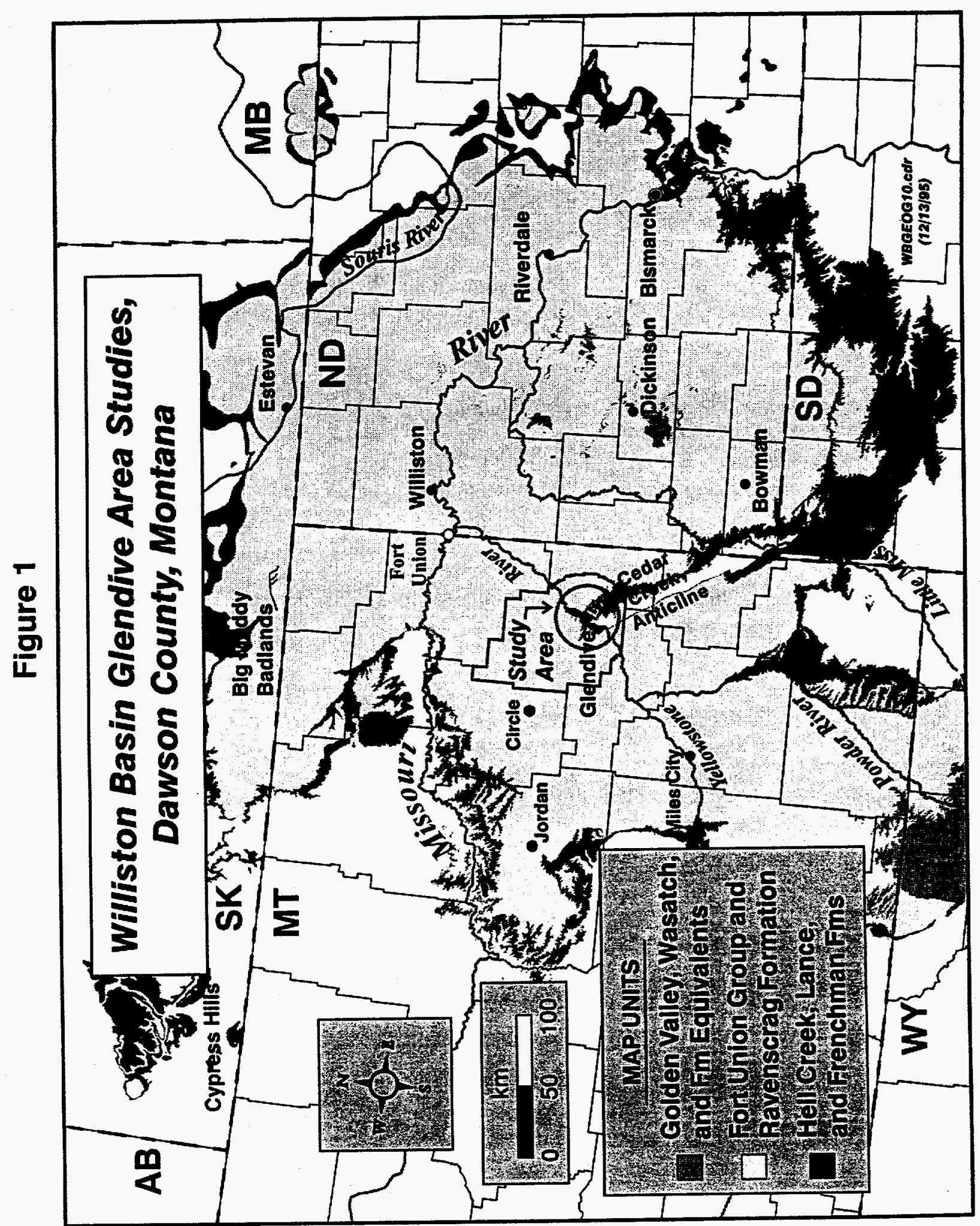


Figure 2

\section{Glendive Area Fossil Stratigraphy}

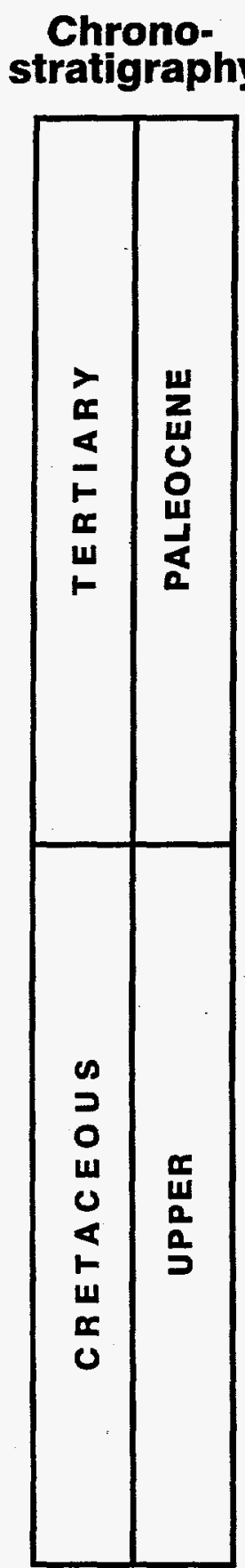

Litho-

stratigraphy

Lignites Locality Horizons

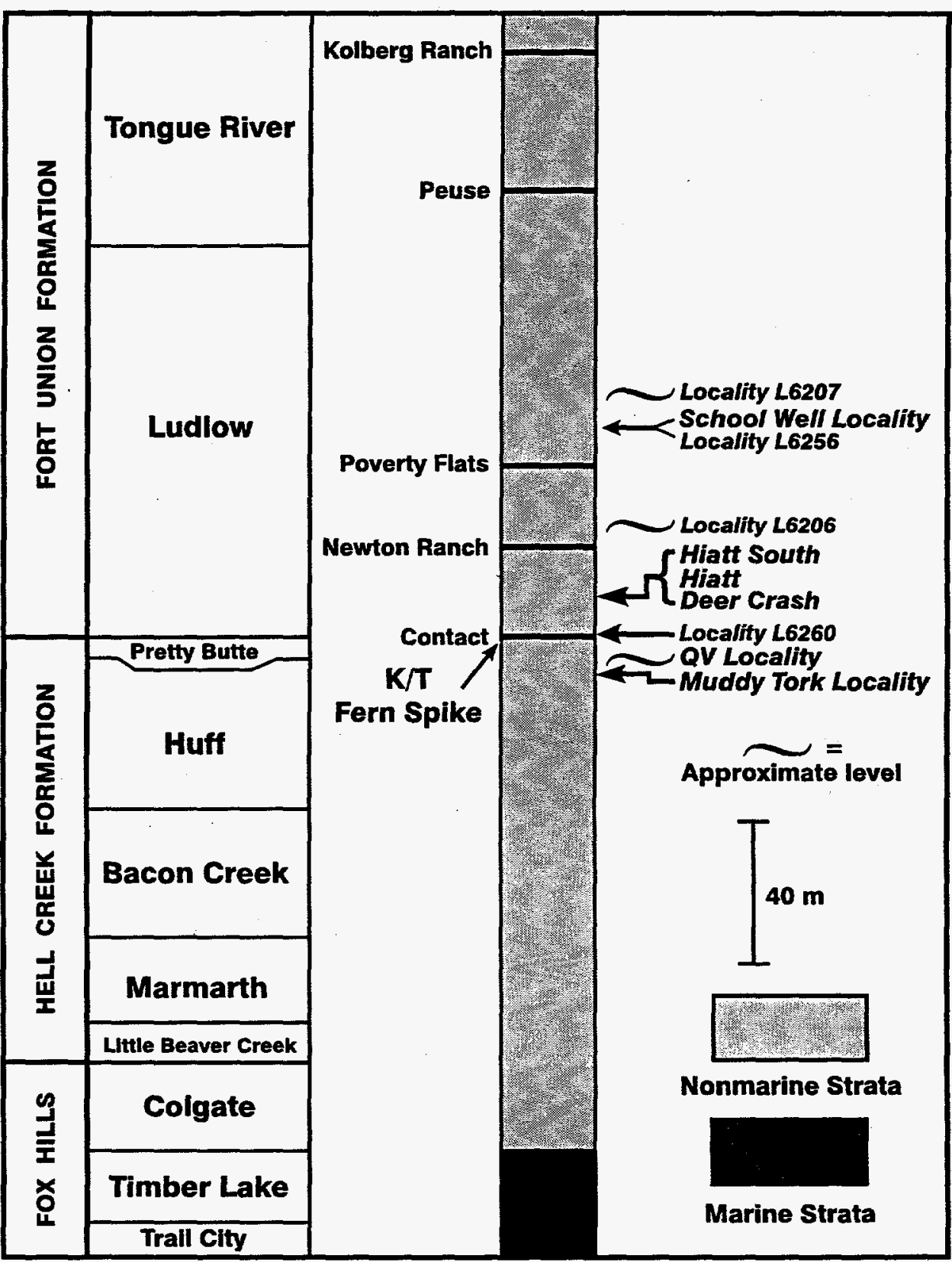

MAK-FMS3.cdr (12/14/95) 


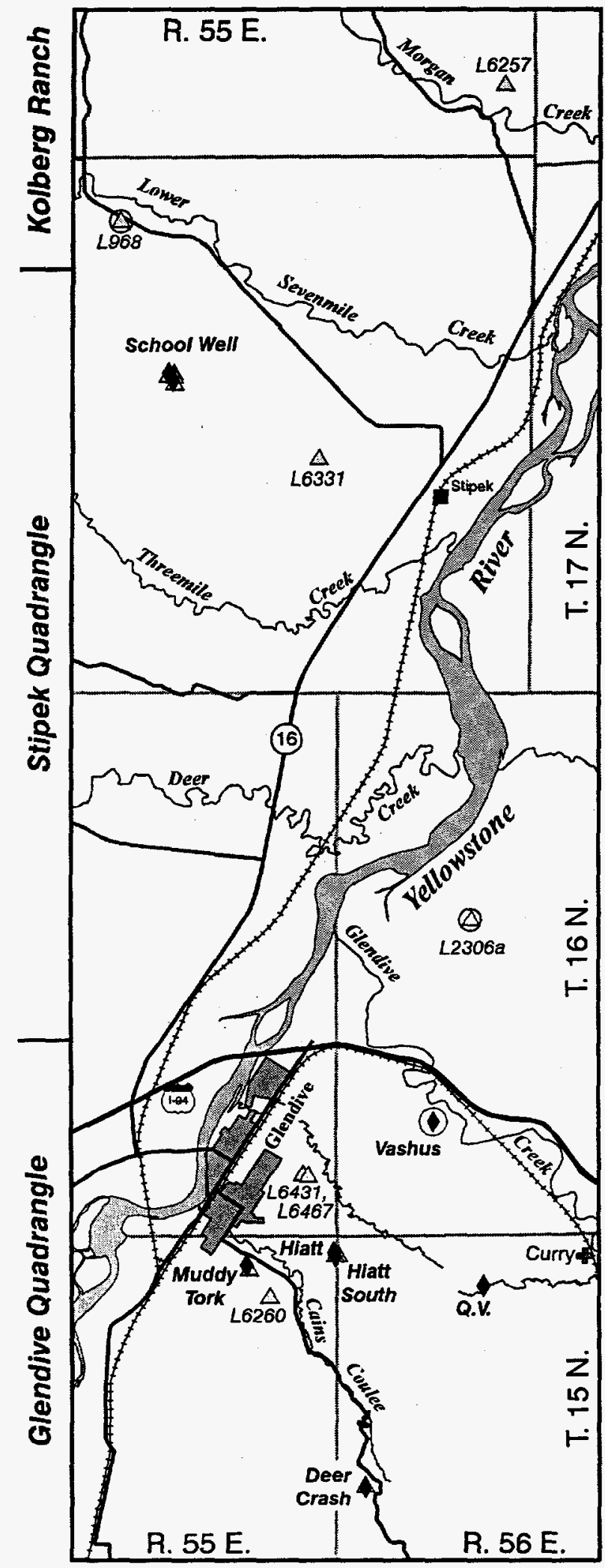

Figure 3

Glendive Area - Makoshika State Park Fossil Localities, Dawson County, Montana
- Mammalian Locality
(-) Mammalian Locality of Uncertain Location
$\triangle$ Molluscan Locality
(4) Molluscan Locality of Uncertain Location

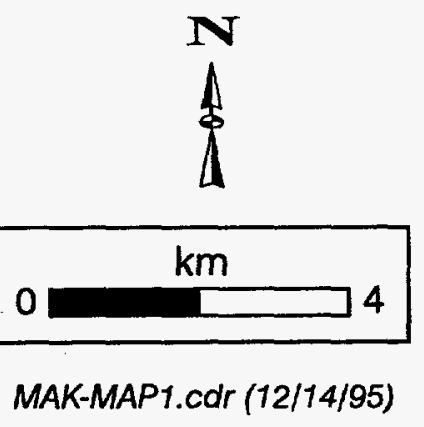


Figure 4

\section{Makoshika State Park - Muddy Tork and Hiatt Area Fossil Localities}

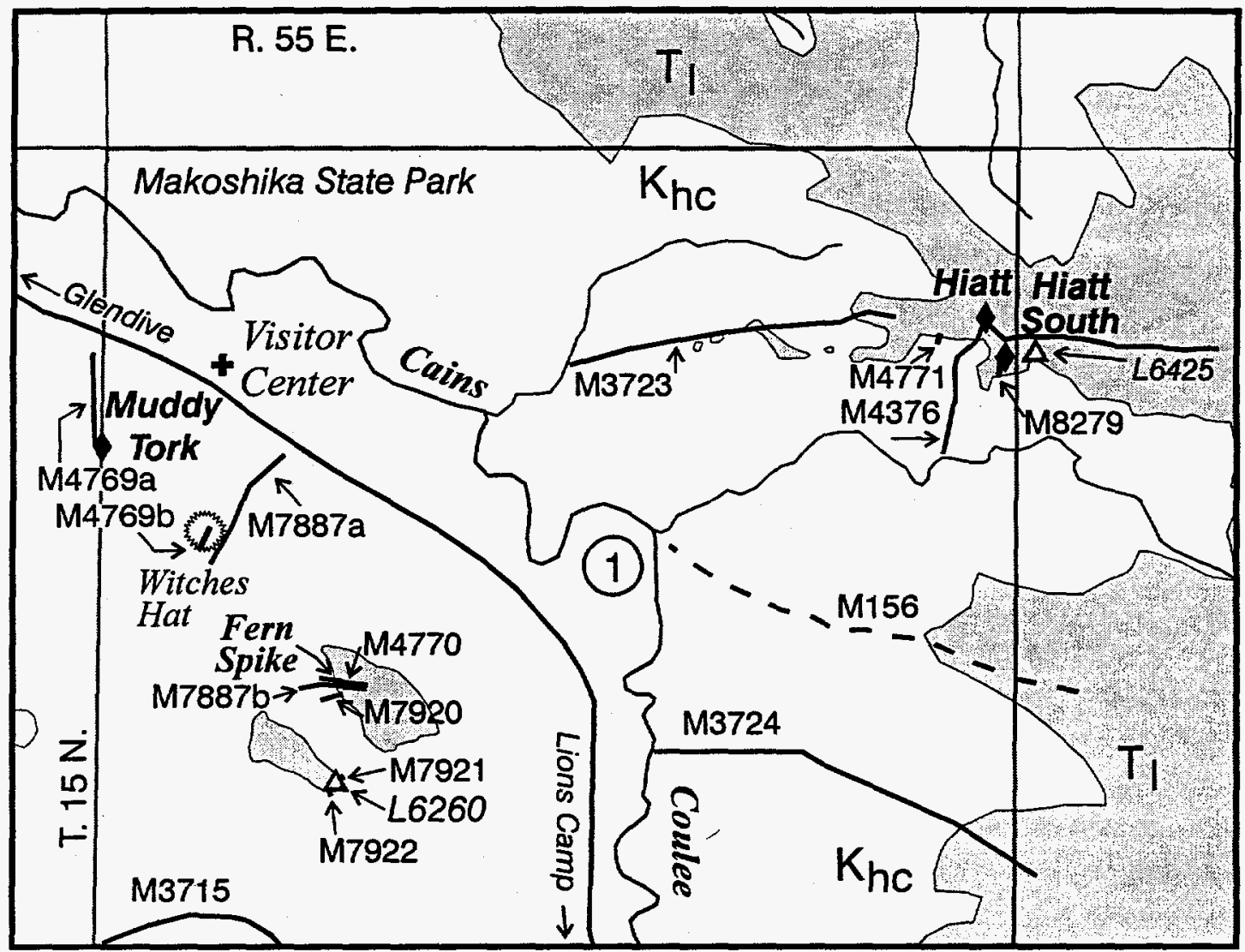

\section{Explanation}

Hiatt Mammalian Locality

$\triangle$ L6260 Molluscan Locality

M7922 Measured Section

_ M156_ Measured Section of

$K_{h c}$ TI Hell Creek $\left(K_{h c}\right)-$

Ludlow $\left(T_{1}\right)$ Contact
(1) = Sec. 1, T. 15 N., R. $55 \mathrm{E}$.

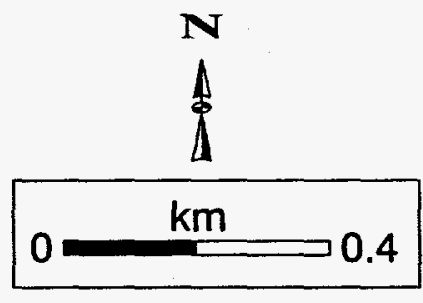

MAK-MAP2.cdr (12/16/95) 
Figure 5

Stratigraphy of Fossil Localities in Sec. 1, T. 15 N., R. 55 E., Makoshika State Park, Montana

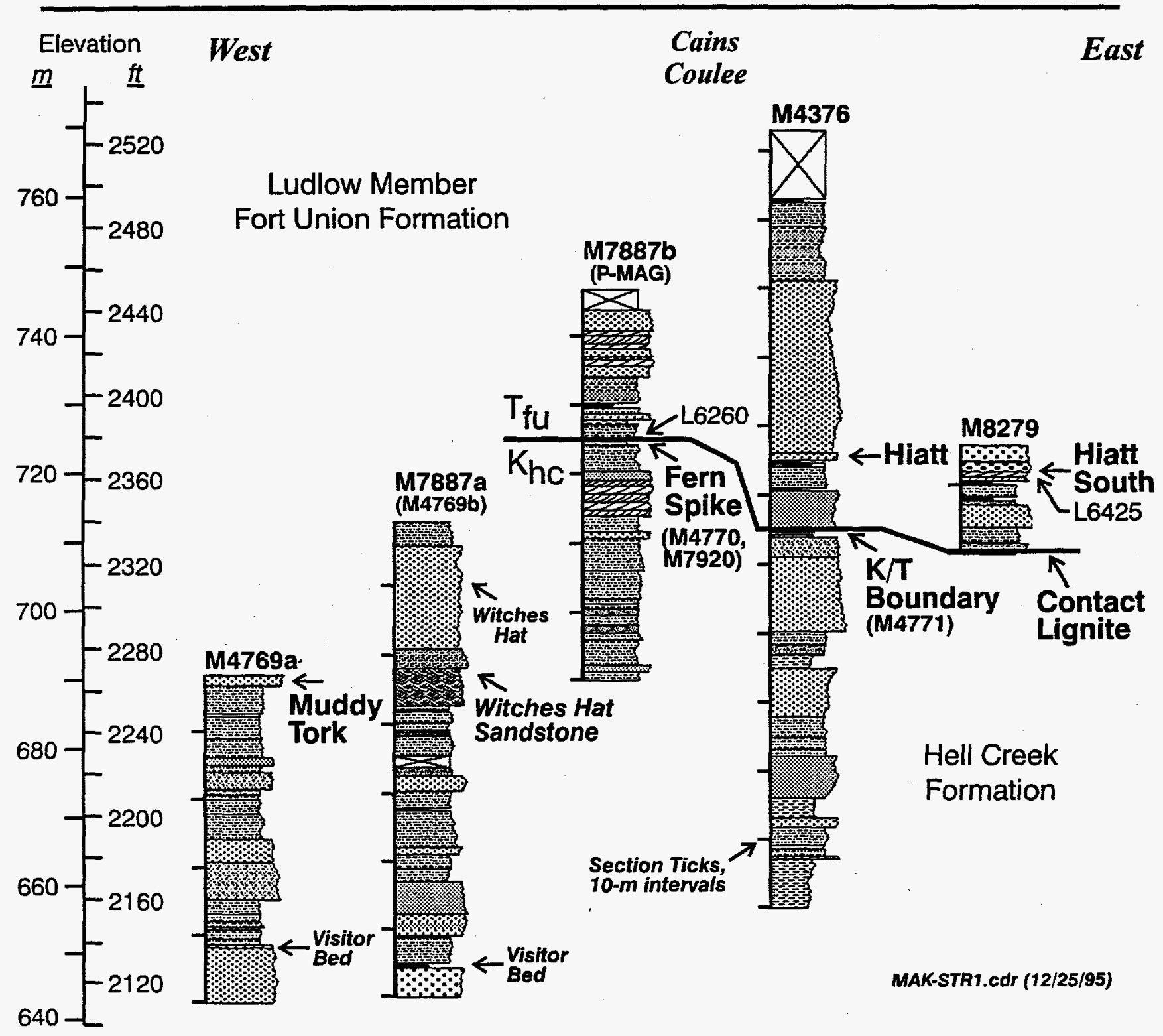


Figure 6

\section{Lithic Symbols for Measured Sections}

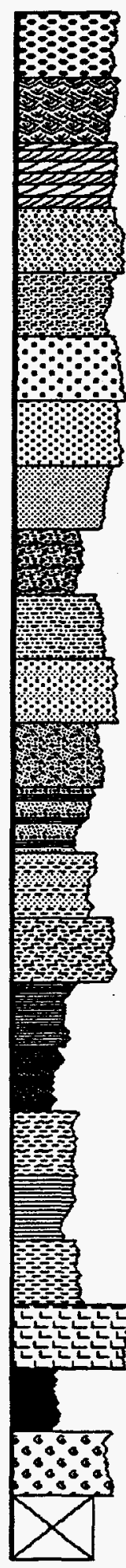

Conglomerate

Sandstone, trough cross-bedded

Sandstone, cross-bedded

Sandstone, silty

Sandstone, shaley or clayey

Sandstone, medium-grained

Sandstone, fine-grained

Sandstone, very fine-grained

Clastics (miscellaneous), lignitic

Mudstone

Siltstone, alternating with sandstone

Siltstone

Shale (claystone), alternating with siltstone and sandstone

Claystone, alternating with siltstone

Shale, calcareous

Shale, lignitic

Shale, carbonaceous

Claystone, smectitic

Shale

Claystone

Clinker or Scoria

Lignite

Fossiliferous

Covered

M-LJTH.cdr (12/26/95) 


\section{Figure 7}

\section{Muddy Tork Locality, Makoshika State Park, Montana}

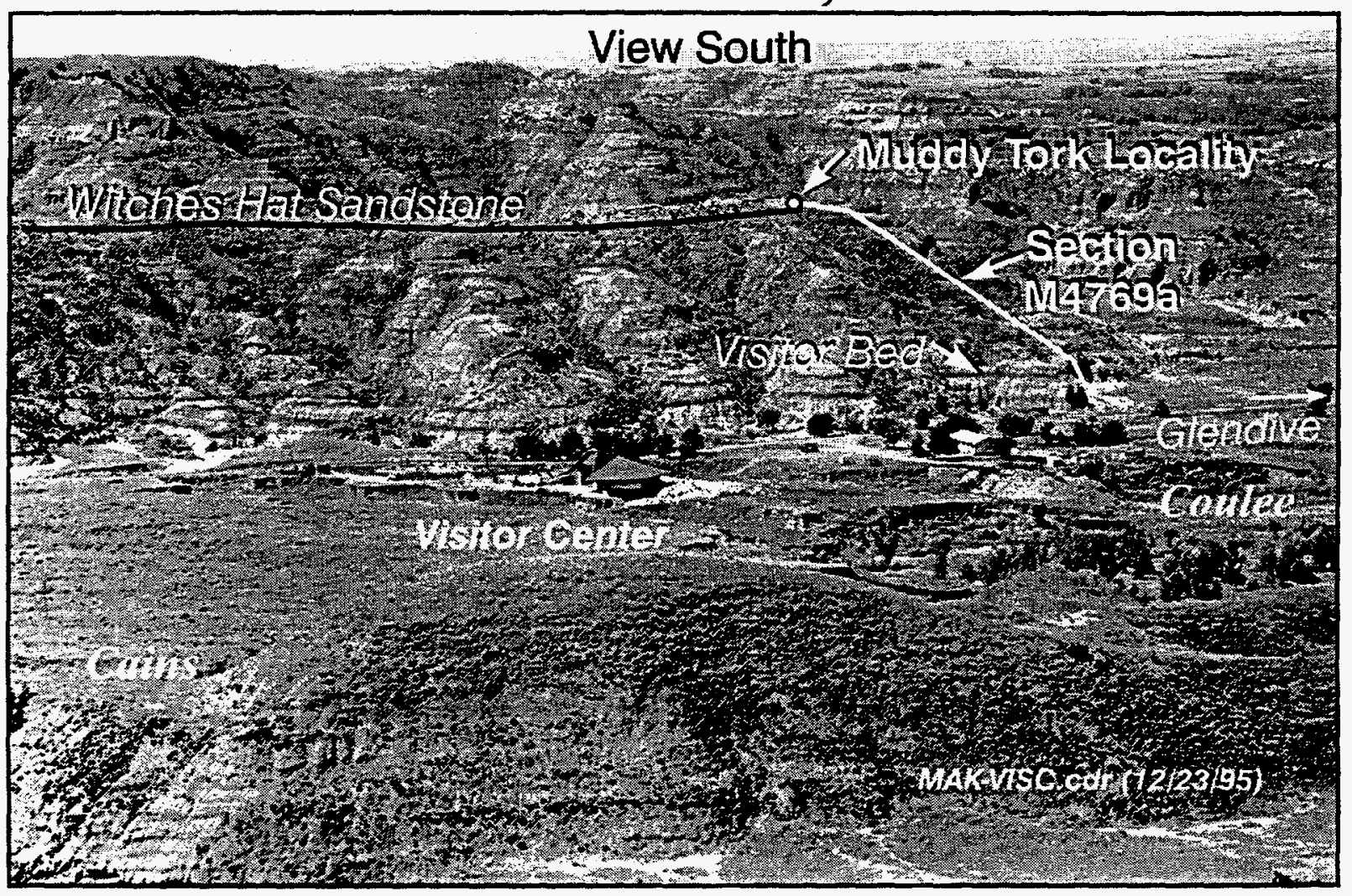


Figure 8

\section{Muddy Tork Locality, Makoshika State Park, Montana}

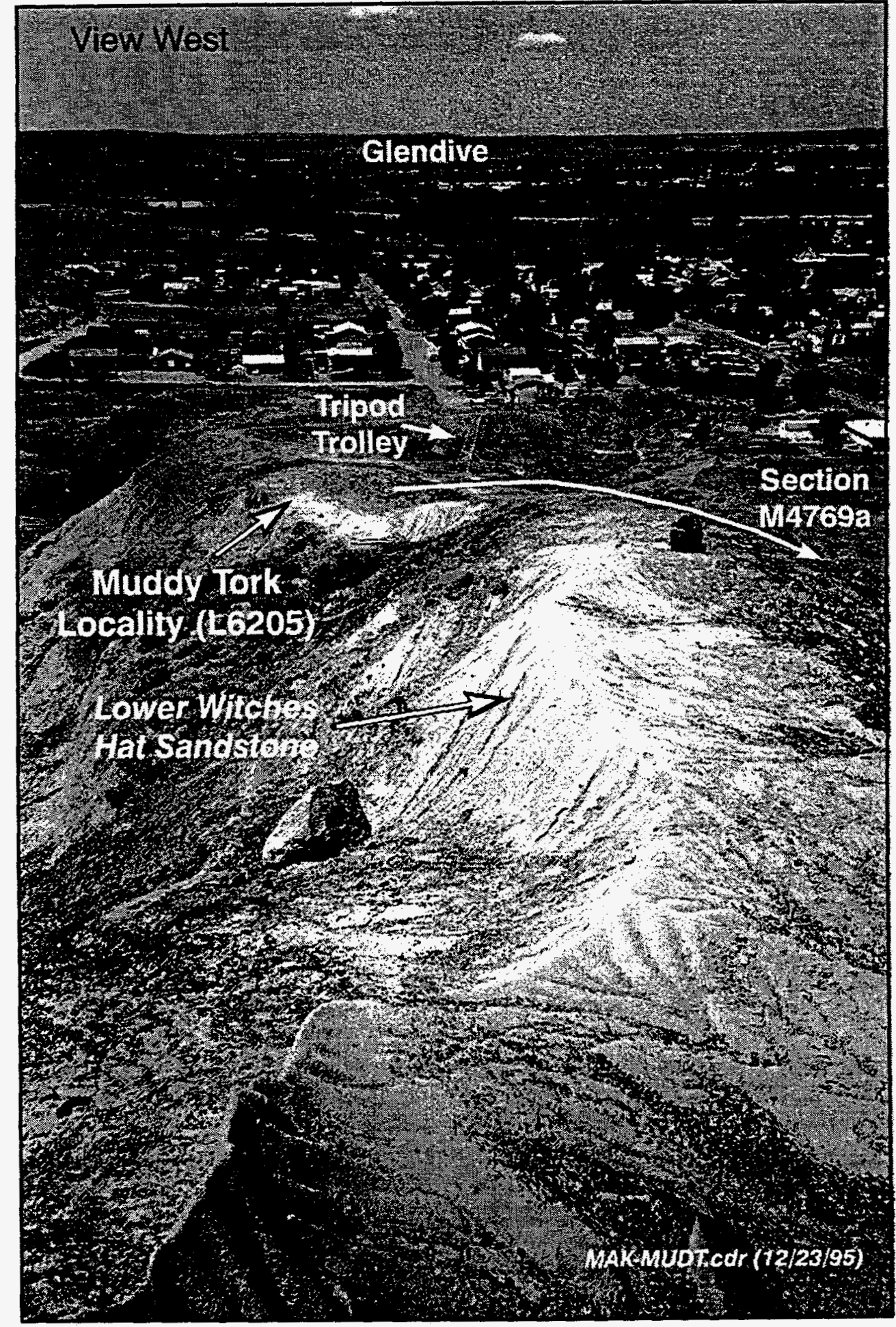




\section{Figure 9 \\ Witches Hat Sections, Makoshika State Park, Montana}

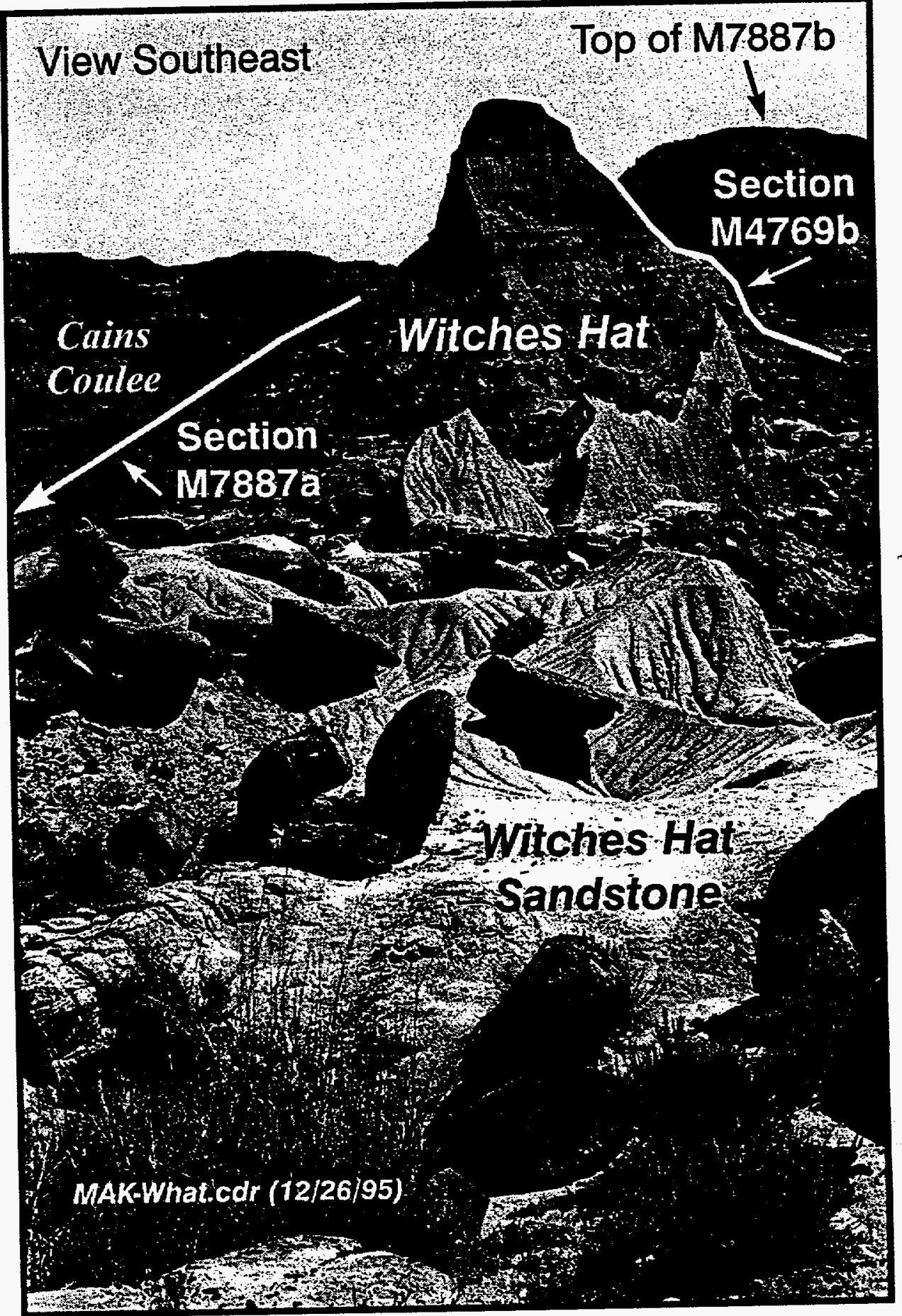


Figure 10

\section{Paleomagnetic, Fern Spike, and K/T Boundary Section, Makoshika State Park, Montana}

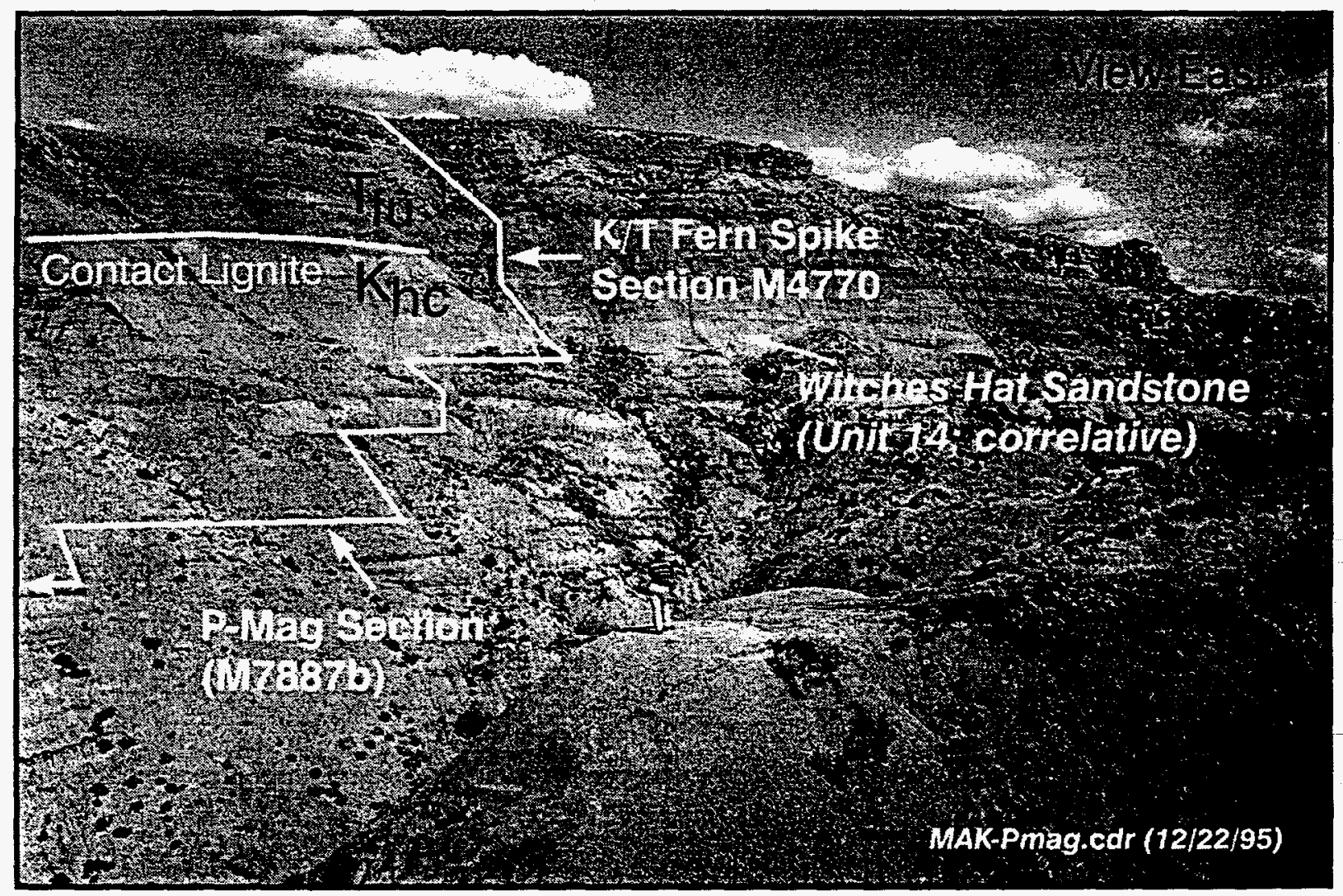


Figure 11

\section{Fern Spike Locality, K/T Boundary Interval, Makoshika State Park, Montana}

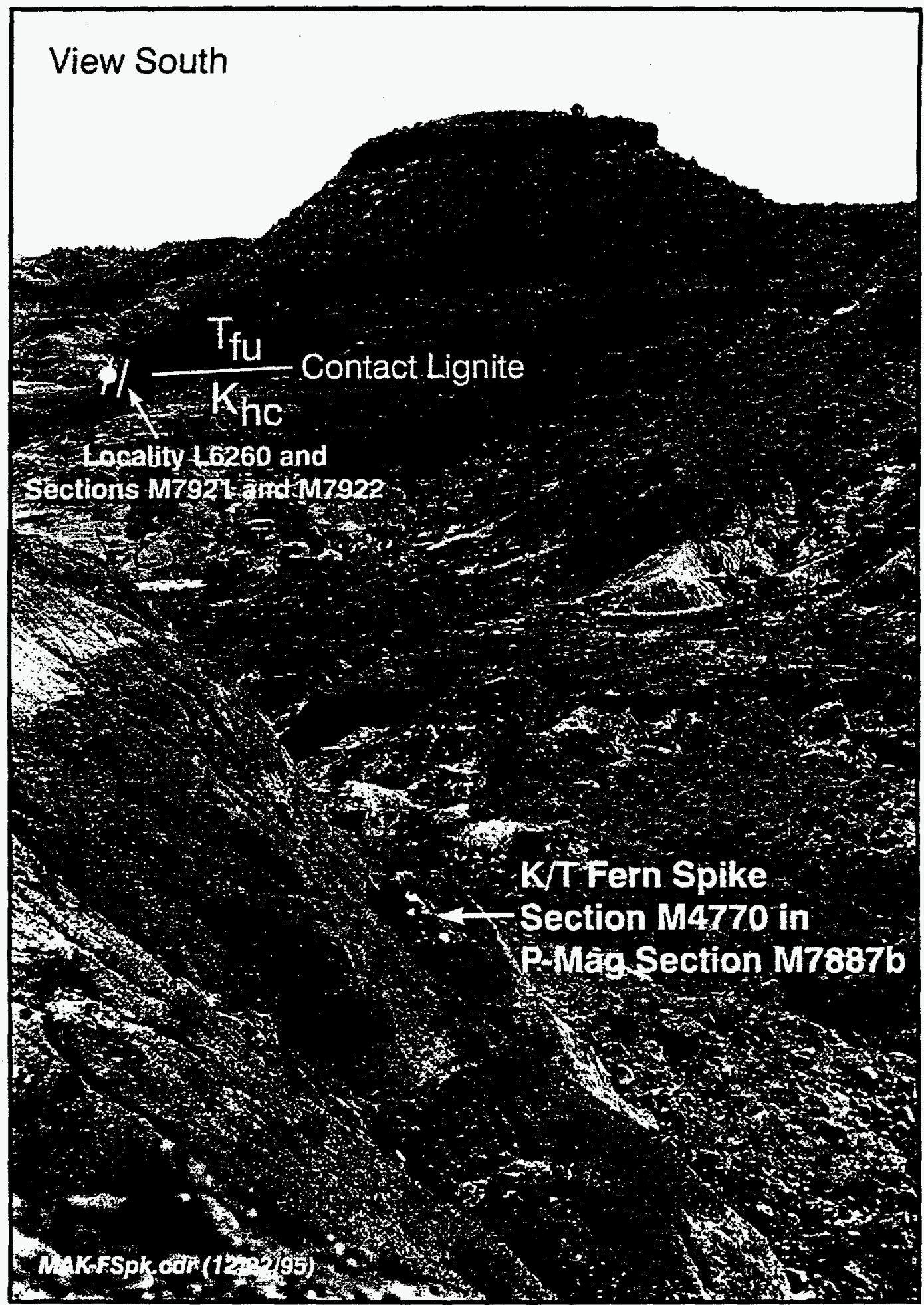


Figure 12

\section{Placement of the K/T Boundary in Makoshika State Park, Montana}

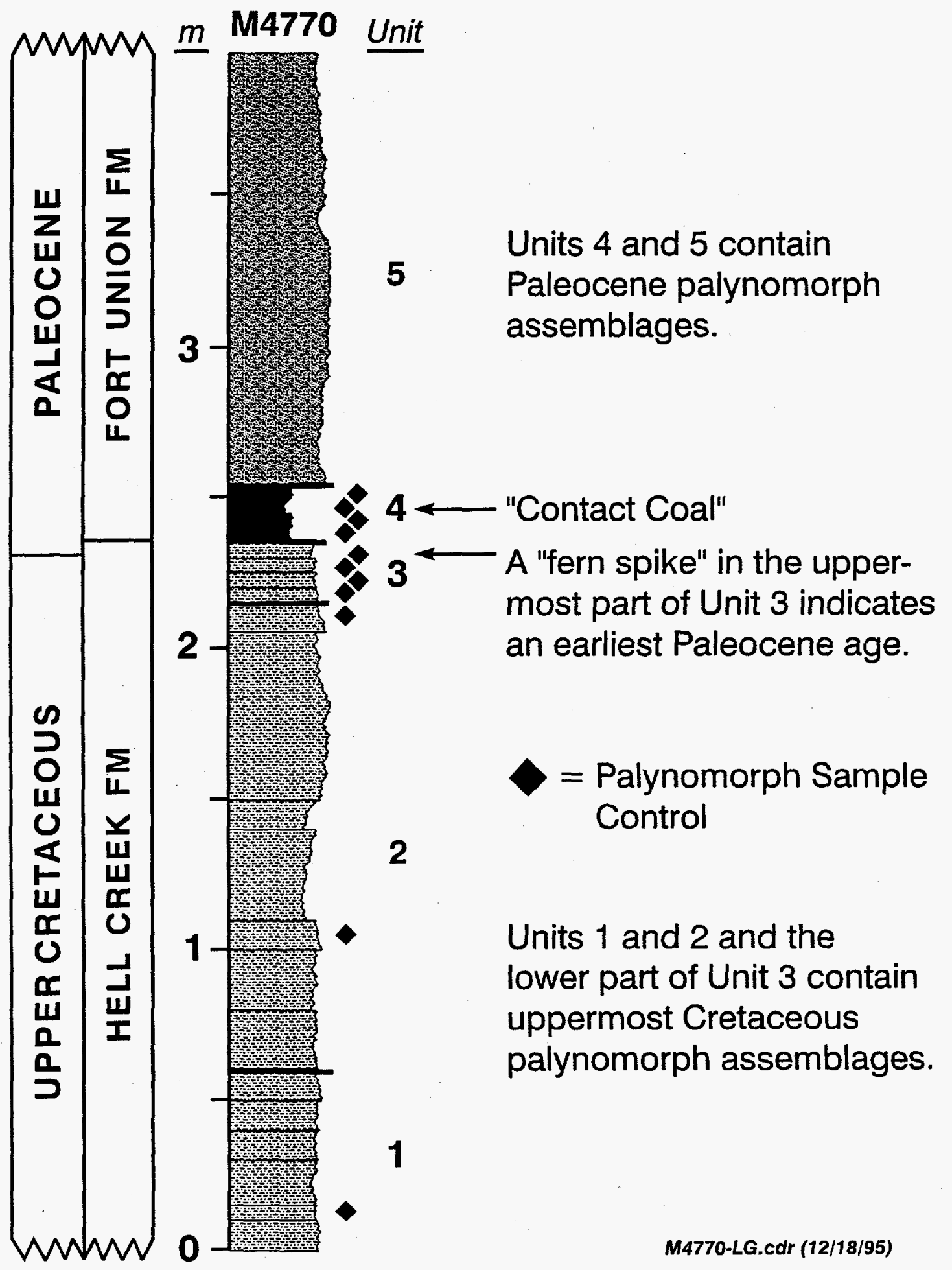


Figure 13a

\section{K/T Boundary Fern Spike, Makoshika State Park, Montana}

Section M4770, Witches Hat Area

5-cm Sample Interval

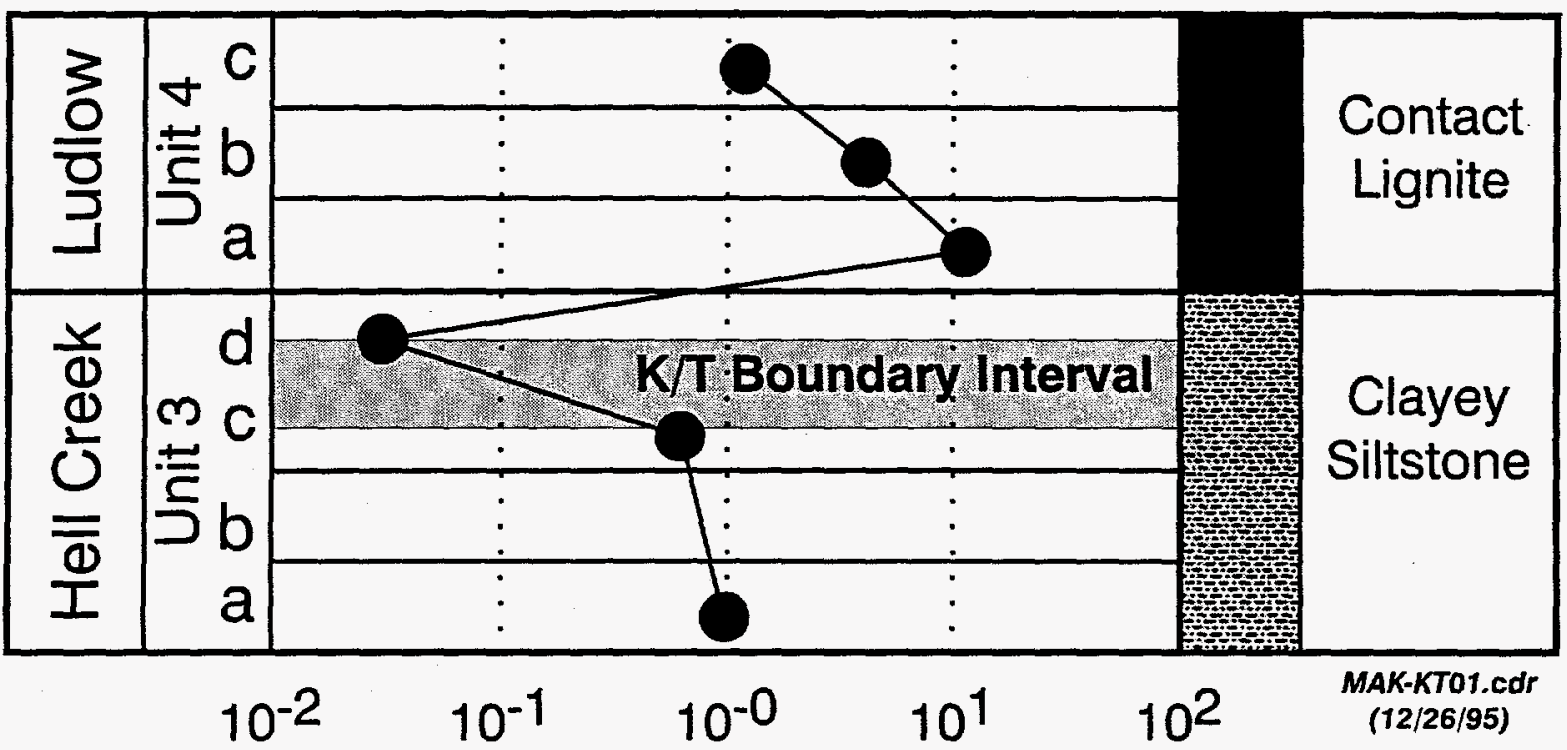

Figure 13b

K/T Boundary Interval Pollen Diagram (excluding fungal and algal taxa)

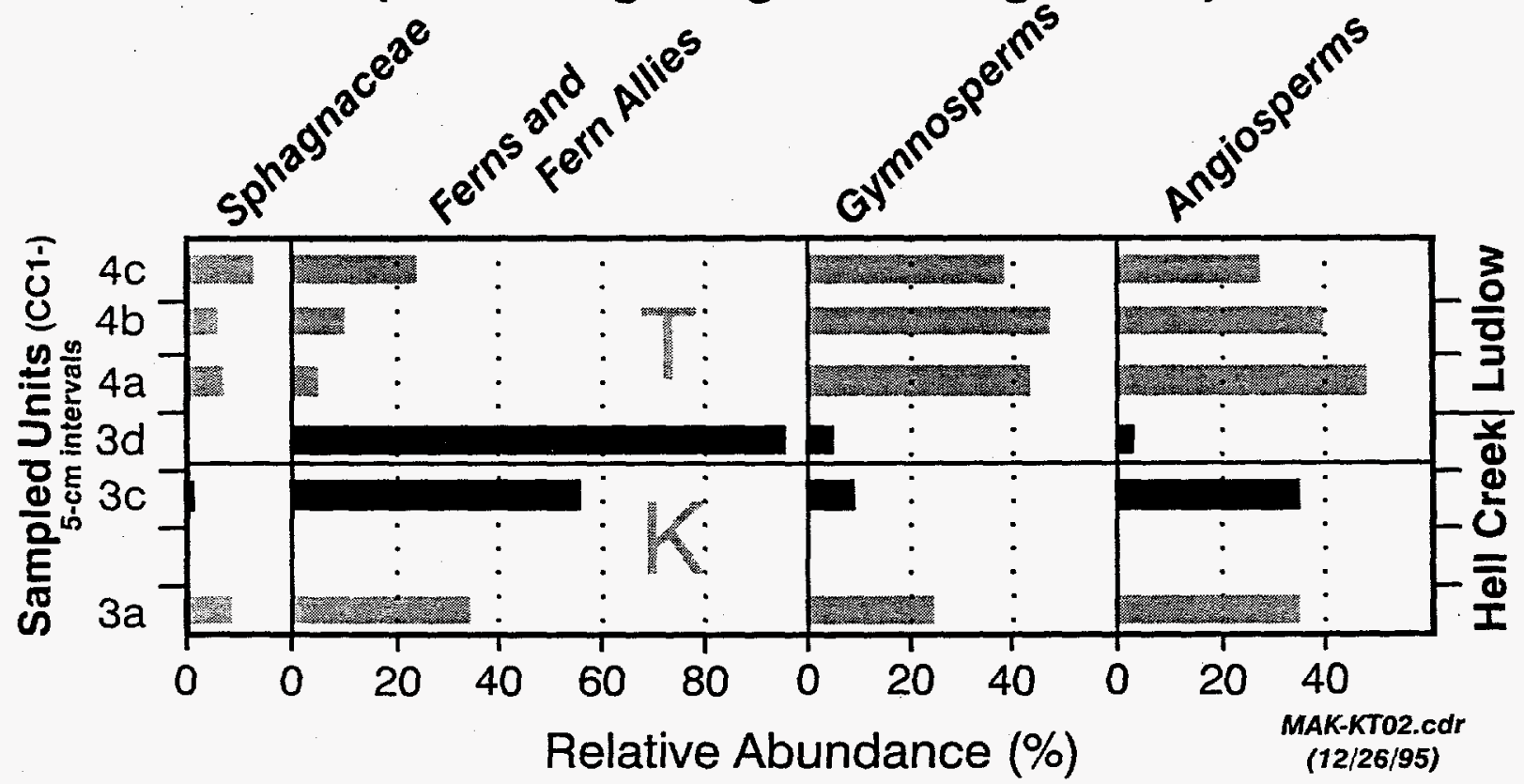


Figure 14

Sand Creek Overlook Sections, Makoshika State Park, Montana

\section{View Northwest}

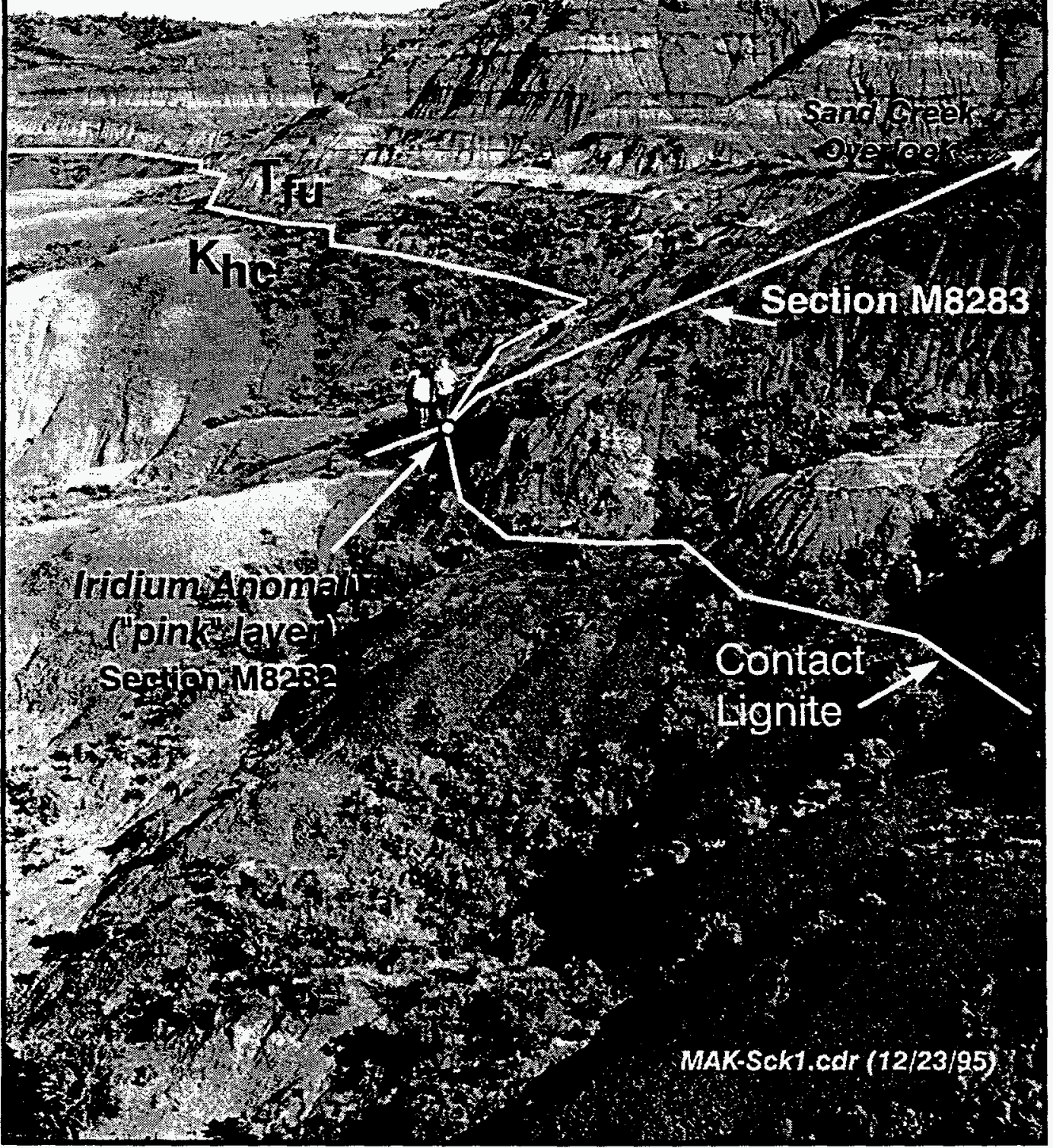


Figure 15

Paleomagnetic Stratigraphy - Fern Spike Section, Makoshika State Park, Montana

Stratigraphy Magnetic Data Age Control

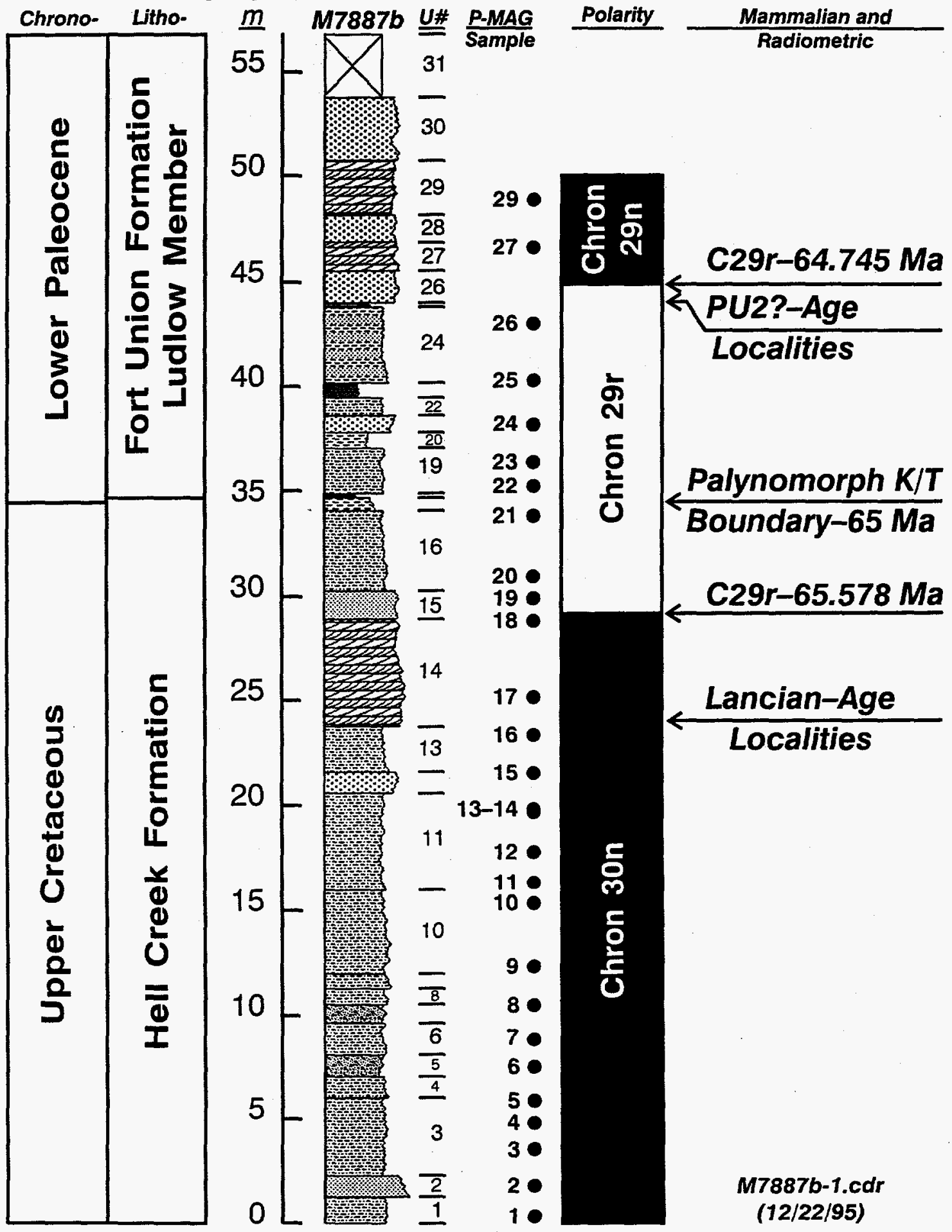


Figure 16 Paleomagnetic Data for Section M7887b,
Makoshika State Park, Montana

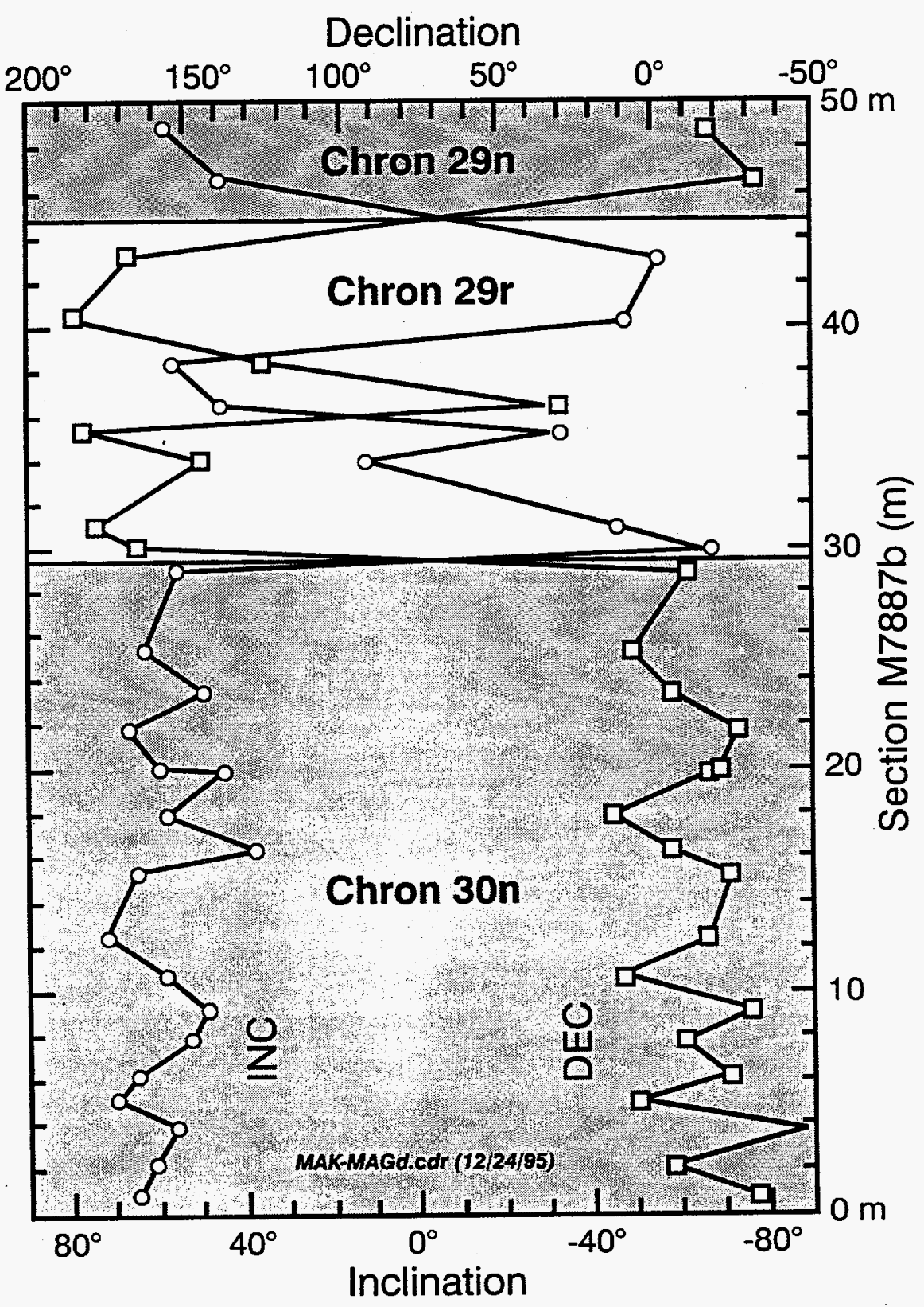


Figure 17

\section{Hiatt and Hiatt South Localities, Makoshika State Park, Montana}

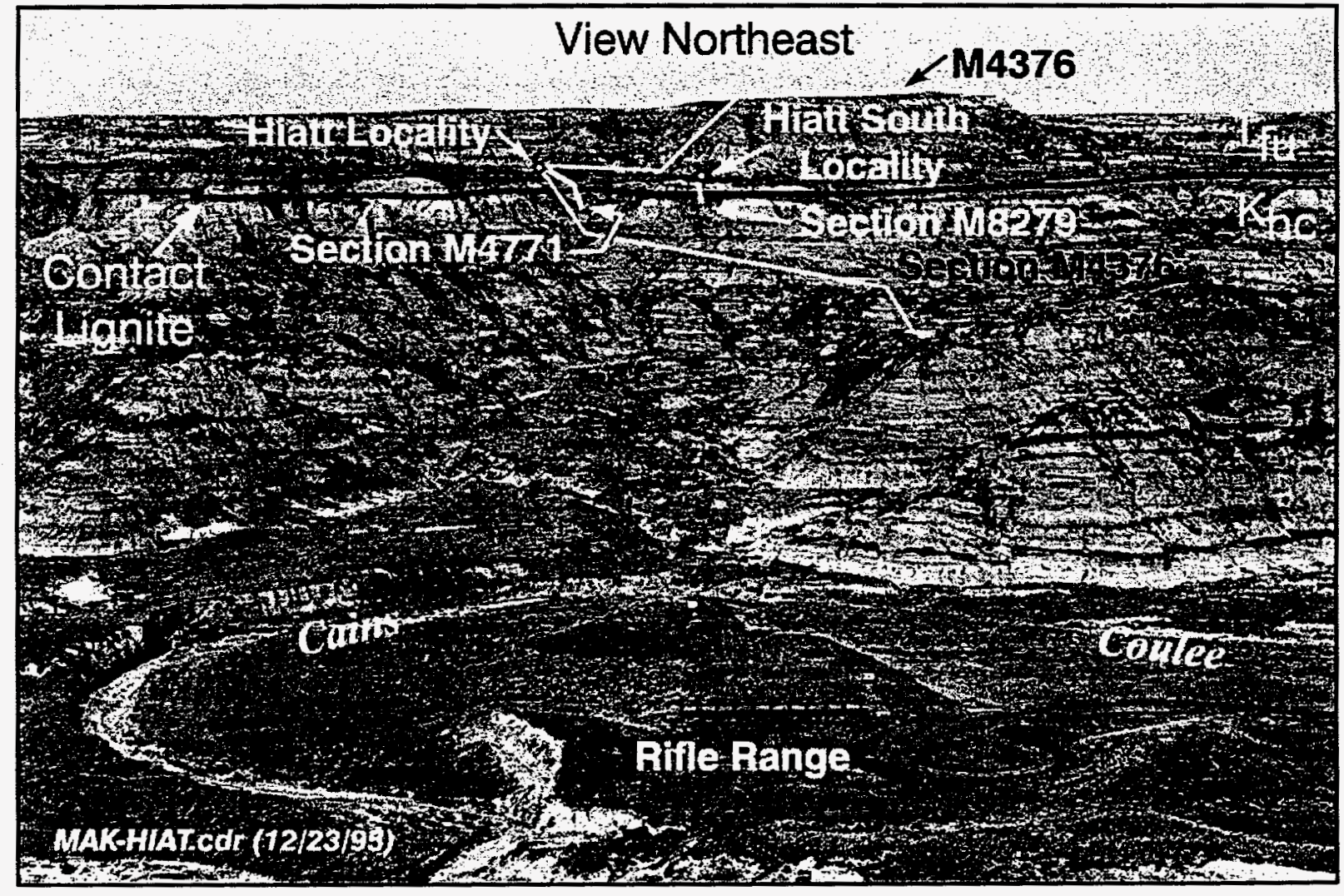


Figure 18

\section{Hiatt South Locality, Makoshika State Park, Montana}

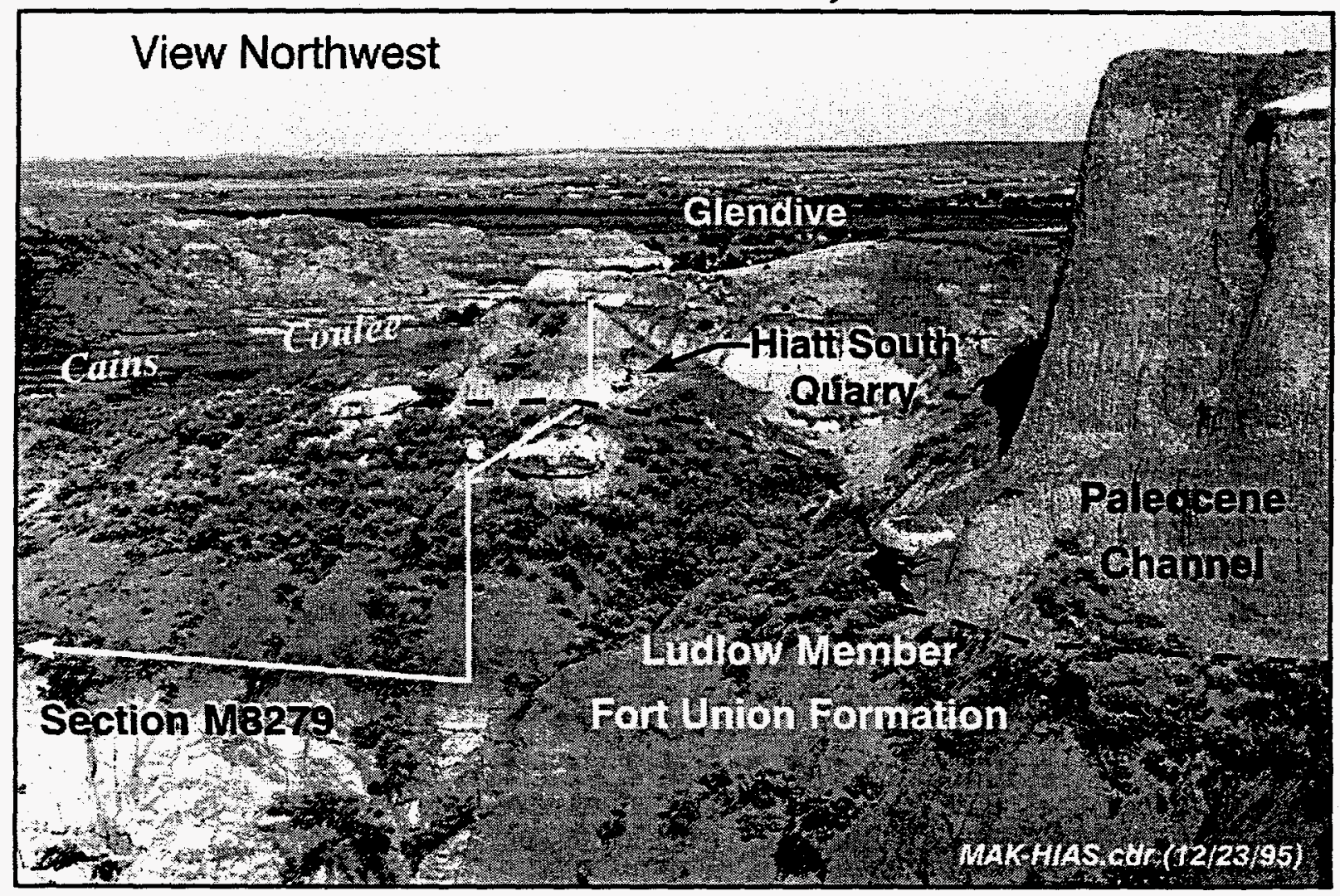


Figure 19

\section{Bulk Sediment Screen Washing,} Yellowstone River, Glendive, Montana

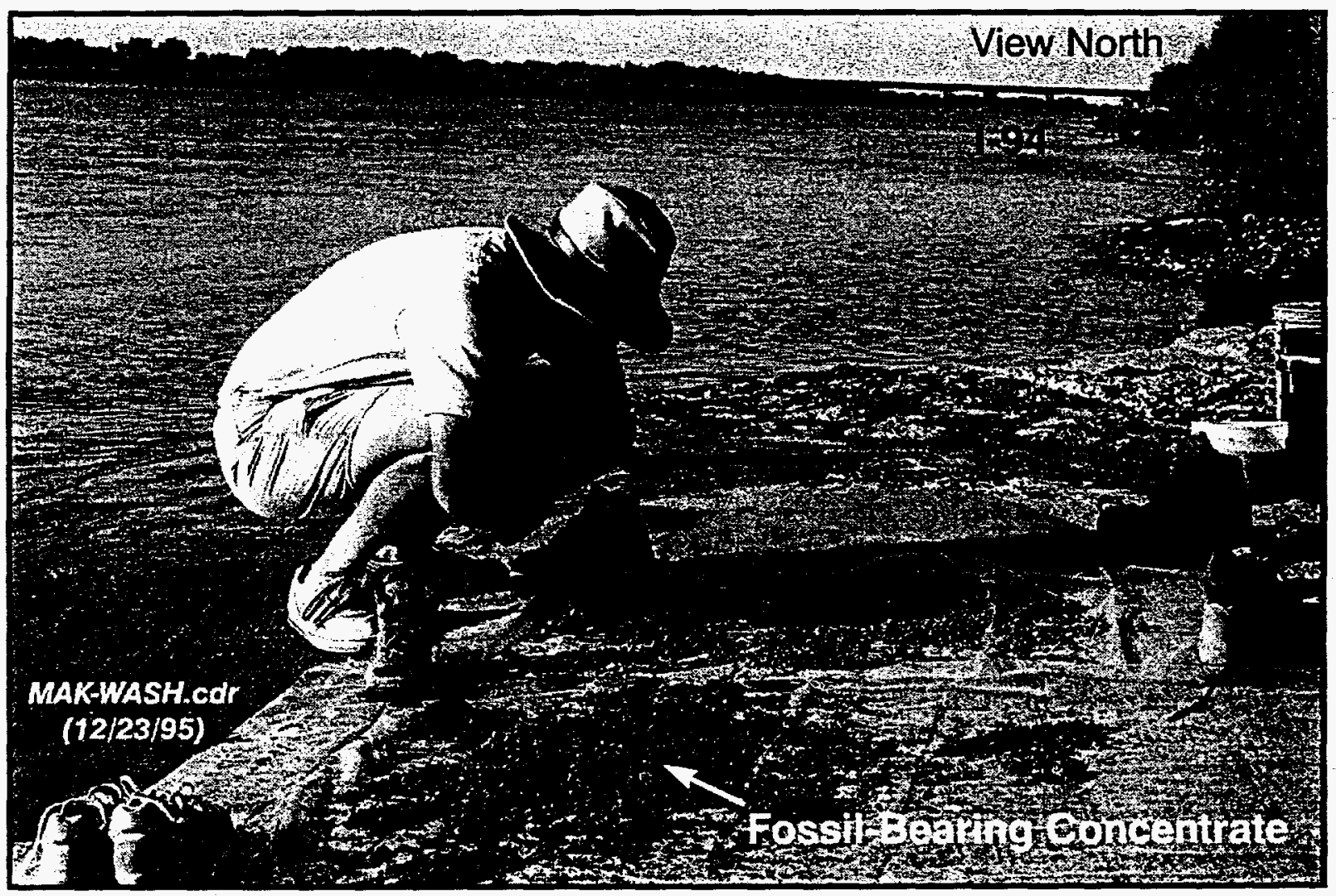




\section{Chronostratigraphy of North Dakota Strata}

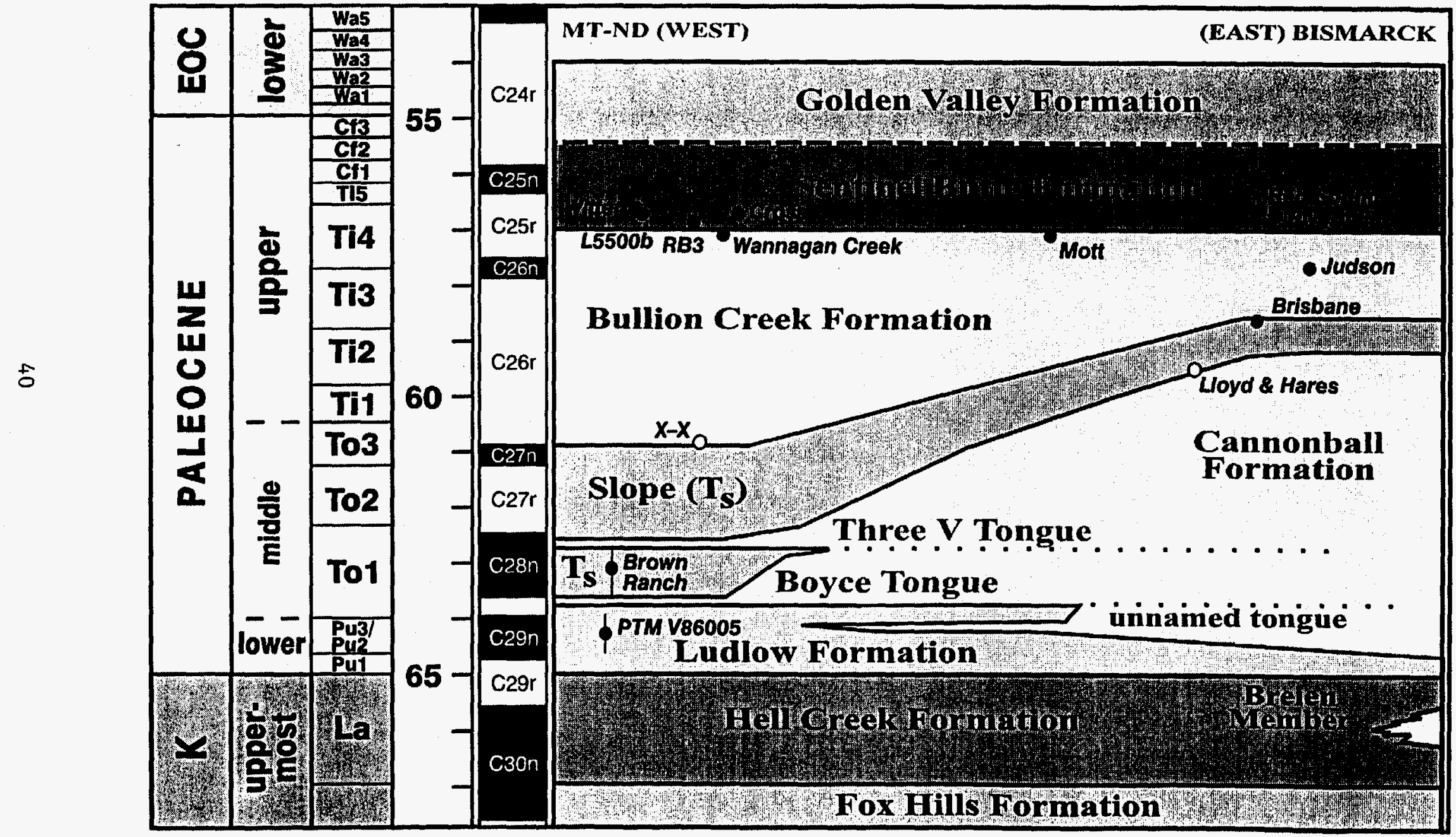




\section{APPENDIX I}

\section{SUMMARY INFORMATION ON MAMMALIAN FOSSIL}

\section{LOCALITIES, GLENDIVE AREA, MONTANA}




\title{
APPENDIX I
}

\author{
Summary Information on Mammalian Fossil Localities, \\ Glendive Area, Montana
}

\section{Hell Creek Formation Localities}

Muddy Tork Locality (L6205). This Upper Cretaceous locality is correlated to be about $11 \mathrm{~m}$ below the Cretaceous-Tertiary boundary and is in the basal part of the sandstone forming the feature known as Witches Hat. The Muddy Tork Locality occurs in sec. 2, T. 15 N., R. 55 E. on land owned by Dawson County Community College, located just outside of Makoshika State Park on the Glendive Quadrangle (1967), Dawson County, Montana. The locality was discovered by Dr. Robert Hiatt of Glendive as a nonmammalian vertebrate locality and has been locally referred to as Tyrannosaurus Peak (see Makoshika State Park Road Guide, Montana Department of Fish, Wildlife and Parks,, 1985). As a mammalian locality, Muddy Tork was rediscovered in 1992 and is locally the most productive Lancian-age locality. A few snail steinkerns were also found at this locality.

Q.V. Locality (L6261). This locality is stratigraphically nearly equivalent to the Muddy Tork Locality and is near the base of a thick channel sandstone complex. The Q.V. Locality occurs in sec. 5, T. 15 N., R. 56 E., in Makoshika State Park on the Glendive Quadrangle (1967), Dawson County, Montana. The Q.V. Locality was discovered in 1993 and to date has produced only a few teeth and one snail steinkern.

Vashus Locality (L6239). This locality is probably from the upper part of the Hell Creek Formation. The Vashus Locality, which may consist of sites at more than one location, is located south of Glendive Creek in the approximate area of sec. 29, T. 16 N., R. 56 E., Glendive Quadrangle, Dawson County, Montana. The three well-preserved jaws known from this locality were collected in the early or middle 1930 s by the Vashus family.

\section{Fort Union Formation (Ludlow Member) Localities}

Hiatt Locality (L5418). This early Paleocene locality is about $10 \mathrm{~m}$ above the K/T boundary and is in the basal portion of a thick sequence of channel sandstones. The Hiatt Locality occurs in sec. 1, T. 15 N., R. 55 E., in Makoshika State Park, Glendive Quadrangle (1967), Dawson County, Montana. The Hiatt Locality was discovered in 1965 by Dr. Robert Hiatt of Glendive. Over the years, Dr. Hiatt and our research group have collected a number of surface-picked teeth. Bulk sampling of this locality has proven to be unproductive.

Hiatt South Locality (L6424). This locality is stratigraphically equivalent to the Hiatt Locality and is in the lowermost part of the intraclastic conglomeratic facies of a sequence of stacked channel sandstones. The Hiatt South Locality is located south of the Hiatt Locality along the same general upland surface in sec. 1, T. 15 N., R. 55 E., in Makoshika State Park, Glendive Quadrangle (1967), Dawson County, Montana. This highly productive locality was discovered in 1993, with significant collecting efforts occurring in 1994 centered on this locality. A few poor-quality freshwater mollusks have also been found at this locality. 


\section{Fort Union Formation (Ludlow Member) Localities (continued)}

Deer Crash Locality (L6426). This site is also apparently stratigraphically equivalent to the horizons of the Hiatt and Hiatt South Localities and is likewise at the base of a major channel sandstone. The Deer Crash Locality is located in sec. 18, T. 15 N., R. 56 E., in Makoshika State Park, Glendive Quadrangle (1967), Dawson County, Montana. This locality was discovered in 1994 and has produced but one identifiable mammalian tooth. It is the only site in the park area that has produced specimens of freshwater clams (Unionidae).

School Well Locality (L6427a, b). The School Well Locality is the only mammalian locality known from the upper part of the Ludlow Member. Attempts to determine its exact stratigraphic horizon have proven difficult, as previously mapped interpretations of the Contact lignite at the base of the Fort Union Formation have been shown to be in error in this area (J.H. Hartman, unpublished data). The locality has been approximated to be about $60 \mathrm{~m}$ above the Hell Creek-Fort Union formational contact and occurs in the lowermost part of a thick channel sandstone. The School Well Locality is on private land to the northwest of Glendive in sec. 17, T. 17 N., R. 55 E., Stipek Quadrangle, Dawson County, Montana. The locality, which was discovered in 1993, has subsequently produced a few teeth and has laterally associated mollusk-bearing sediments (L6256a, b). 
APPENDIX II

MAMMALIAN FAUNAS FOR FOSSILIFEROUS STRATA, GLENDIVE AREA, MONTANA 


\section{APPENDEX II \\ Mammalian Faunas for Fossiliferous Strata, Glendive Area, Montana}

\section{The Muddy Tork Fauna (Cretaceous - Lancian)}

The mammals recovered from the Hell Creek Formation indicate a Late Cretaceous age (Lancian Land Mammal Age) and show ties with forms from localities elsewhere in Montana and in Wyoming differing from assemblages found at more northern latitudes in Canada. Pediomyid marsupials are diverse, and the multituberculate Meniscoessus is abundant. No eutherians and only one peradectid marsupial, Turgidodon rhaister, have been recovered.

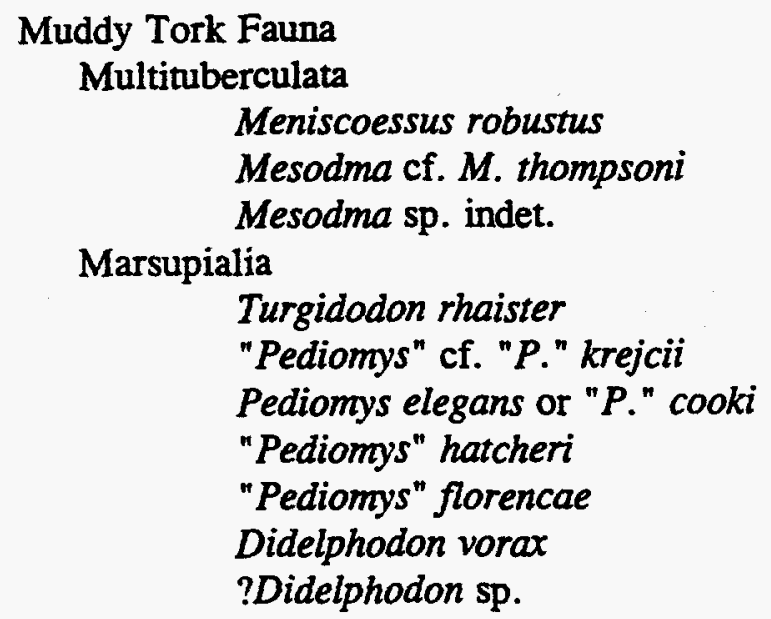

The Hiatt Locality Fauna (Paleocene - Puercan)

The mammalian fauna recovered from the lowest part of the Fort Union Formation indicates an early Paleocene age (?Pu2 interval zone of the Puercan Land Mammal Age) and shows similarities to other early Paleocene faunas in Montana and Canada.

\section{Hiatt Locality Fauna}

Multituberculata

Neoplagiaulax cf. $N$. kremnus

Neoplagiaulax sp.

Neoplagiaulacidae, gen. \& sp. indet.

Stygimys sp.

?Ectypodus

Condylarthra

Baioconodon cf. $B$. nordicum

Loxolophus schizophrenus

Loxolophus sp.

?Oxyclaenus sp.

?Carcinodon sp. 
Appendix II (continued)

The Hiatt Locality Fauna (continued)

Tinuviel eurydice

Oxyacodon ferronensis

Oxyacodon apiculatus

Eoconodon nidhoggi?

Taeniodonta

Onychodectes tisonensis

The School Well Fauna (Paleocene - Torrejonian)

The fauna recovered from the upper part of the Ludlow member of the Fort Union Formation is middle Paleocene in aspect (Torrejonian Land Mammal Age).

School Well Fauna

Multituberculata

Ptilodus montanus

Condylarthra

Litaletes sp.

Promioclaenus sp.

Periptychus sp.

Plesiadapiformes

Paromomys sp. 


\section{APPENDIX III}

\section{STRATIGRAPHIC SECTIONS FOR SIGNIFICANT LOCALITIES IN MAKOSHIKA STATE PARK}




\section{APPENDIX III \\ Stratigraphic Sections for Significant \\ Localities in Makoshika State Park}

See Figure 4 for section locations.

Section M3723: $\quad$ Butler (1980), Section CC2 . . . . . . . . . . . . . . . . . 49

Section M3724: $\quad$ Butler (1980), Section CC3 . . . . . . . . . . . . . . . 51

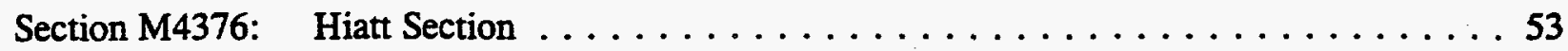

Section M4769a: Muddy Tork Section (Witches Hat Area) . . . . . . . . . . . . 56

Section M4769b: Witches Hat Section $\ldots \ldots \ldots \ldots \ldots \ldots \ldots \ldots \ldots$

Section M4770: Fern Spike Section (Witches Hat Area) . . . . . . . . . . . . . 59

Section M4771: $\quad \mathrm{K} / \mathrm{T}$ Boundary Section (Hiatt Area) $\ldots \ldots \ldots \ldots 2$

Section M6723: $\quad$ First P-Mag Section $\ldots \ldots \ldots \ldots \ldots \ldots$

Section M7887a: Witches Hat Section $\ldots \ldots \ldots \ldots \ldots$

Section M7887b: P-Mag Section (Witches Hat Area) $\ldots \ldots \ldots \ldots$

Section M7920: $\quad$ Boundary Section $\mathrm{CC1}$ (Hiatt Area) $\ldots \ldots \ldots \ldots$

Section M7921: $\quad$ Boundary Section CC4 (Witches Hat Area) . . . . . . . . . . . 69

Section M7922: $\quad$ Boundary Section CC5 (Witches Hat Area) $\ldots \ldots \ldots \ldots \ldots$

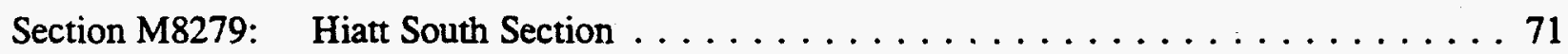

Section M8283: $\quad$ Sand Creek Overlook Section $\ldots \ldots \ldots \ldots \ldots \ldots \ldots$ 


\section{Measured Section M3723 (Butler, 1980, Section CCC2) (Elevations given in feet for use with topographic quadrangle)}

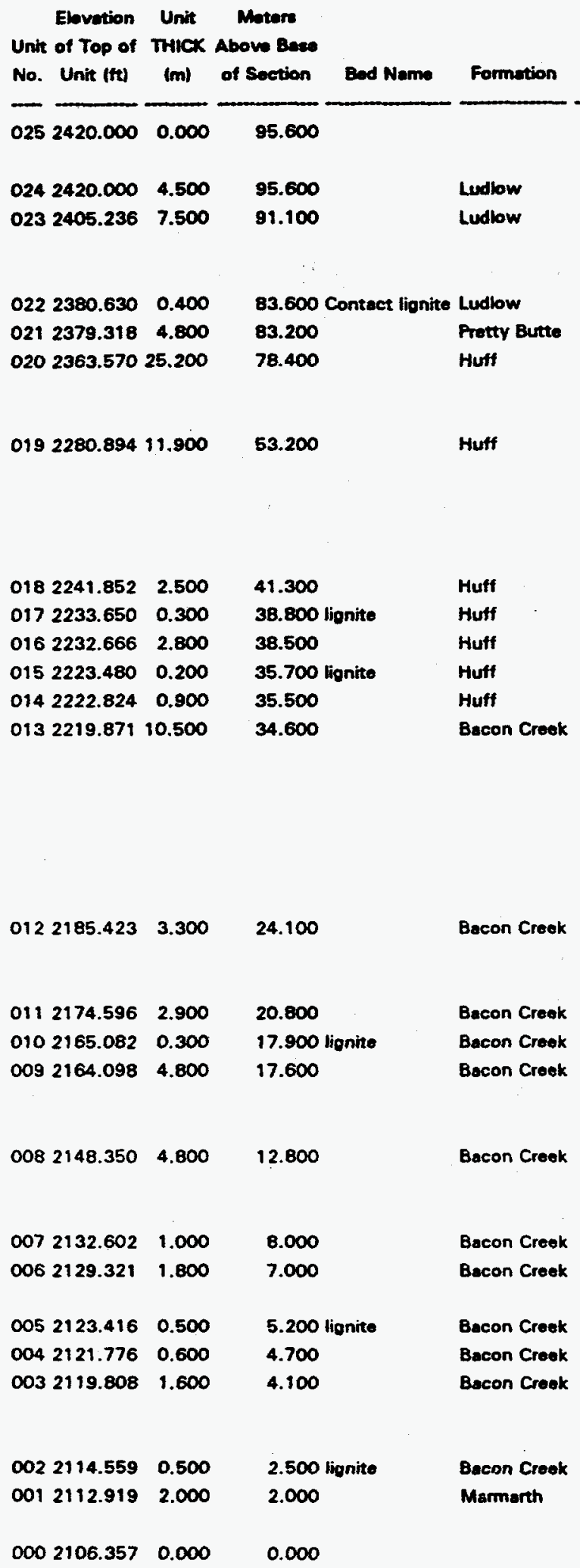

\begin{abstract}
Rock
\end{abstract}
Somple No.

Lithologic Daseription

Top of Section. Formation (member) names asuignod by Burtor (1980).

"Sandztone; no discamible atructures; pertly covened."

"Sandetone, fine, yellowieh gray to light olive gray; erosional bece: very-lerge-ecele sets; upper part poorty sortod, very silty: eastorty trend."

"Lipnite, black; persistent."

"Siltrtone, sandy (bace) to shaly and lianitic (top)."

"Sandatone, fine to wery fine. clayey, yellowiah groy to liaht olive oray; parts poorly consolidated; abundent concretions; arosional base; parts poorly sorted: larpo- and very-leroo-sealo sets."

"Sandetone, fine, light olive gray; lerpe calcereous concretions: large-scale, weakly curved sots of cross strath. pabocurront N87'E to easterly near top of unit, sets thin upwerd: smaltecele. planer. convergent sets; some flat stratification (plane bed): top sitty, chaly. lignitic, and conerotionary."

"Sitstone, sandy; loosely consolidated: jerosite nodubs."

"Lignite."

"Shate, silty, olive grey, poorty sorted."

"Lignite."

"Shale, sitty, olive grey: poorly sorted."

"Sandatone, fine, yellowith oray: fines upward; tabular, calcereous concretions; fish vertebra: targo-ecale groupod, waskly curved to woakly ploner sots of high-angle weskly conceve to atreight croes strate. paleocurrent $562^{\circ} \mathrm{E}$ : intraformational conplomerate 10.5 $m$ ) of shale pebbles; largo-scale $(1.5 \mathrm{~m})$, planar to weakly curved sets with organic matter on bedding pianes, long foreset alopes, abundont shale ciasts and pebble.."

"Silsetone, yellowish oray: fines upward to shale and lignite shale in upper (1.3 m); abundant vertobrate fragments; jarositic and limonitic concretions: erosional top."

"Siltstono, shale, and lignitic shaie."

"Lionite, latorally persistent."

"Shale, silty to lignitic, and lignite, thin; a fow thin sitstone and sondstone beds, yellowish gray. flatly bedded: thin, limonitic concretionary layers."

"Shale, light olive gray to medium light oray: carbonaceous sequence; parts silty and sandy, brittle, fines up to lignitic thate 10.2 mI. pale brown; vertebrate tossils; rootlets."

"Shale, slightiy lignitic."

"Shale, slightly sitty: laminated: hard; poorly sorted; limonite streaks. rootlots."

"Lignite, black, laterally persistent."

"Shale, lionitic."

"Sihtstone and shale: siltstone is sandy, yellow gray to dusky yollow, flatly atratified, rootlots; upper part of unit is ehaly, lignitic; bese is erosional."

"Lignite, brown to bleck: well doveloped."

"Sandatone, fine, silty, yollowizh gray; top thaly; very-largo-seste sets of sigmoidal crose strata."

Base of section "Moasurod section CC2 - T. 15 N., R. 55 E., Soc. 1, NW quarter of NE quarter." Section measured by Butter 11980 ; 


\section{Measured Section M3723 (Butler, 1980, Section CCC2)}

(Elevations given in feet for use with topographic quadrangle)

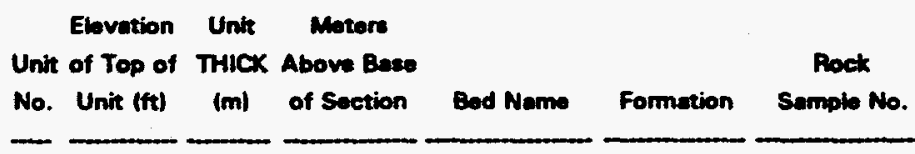

Lithobogic Desecription

beation detemined from an unpublished field map (R.D. Butior, pere. comm.l. The base and top of eoction CC2 ere $2110 \mathrm{th}$ to $2320 \mathrm{th}$ respectively, ropresenting a thickness of $210 \mathrm{ft}$. The clovetions oiven in this form conform to Butier's reported section thicknose. Butier (1980, p. 253) etated the section top elovetion es $2510 \mathrm{ft}$. 


\section{Measured Section M3724 (Butler, 1980, Section CC3) (Elevations given in feet for use with topographic quadrangle)}

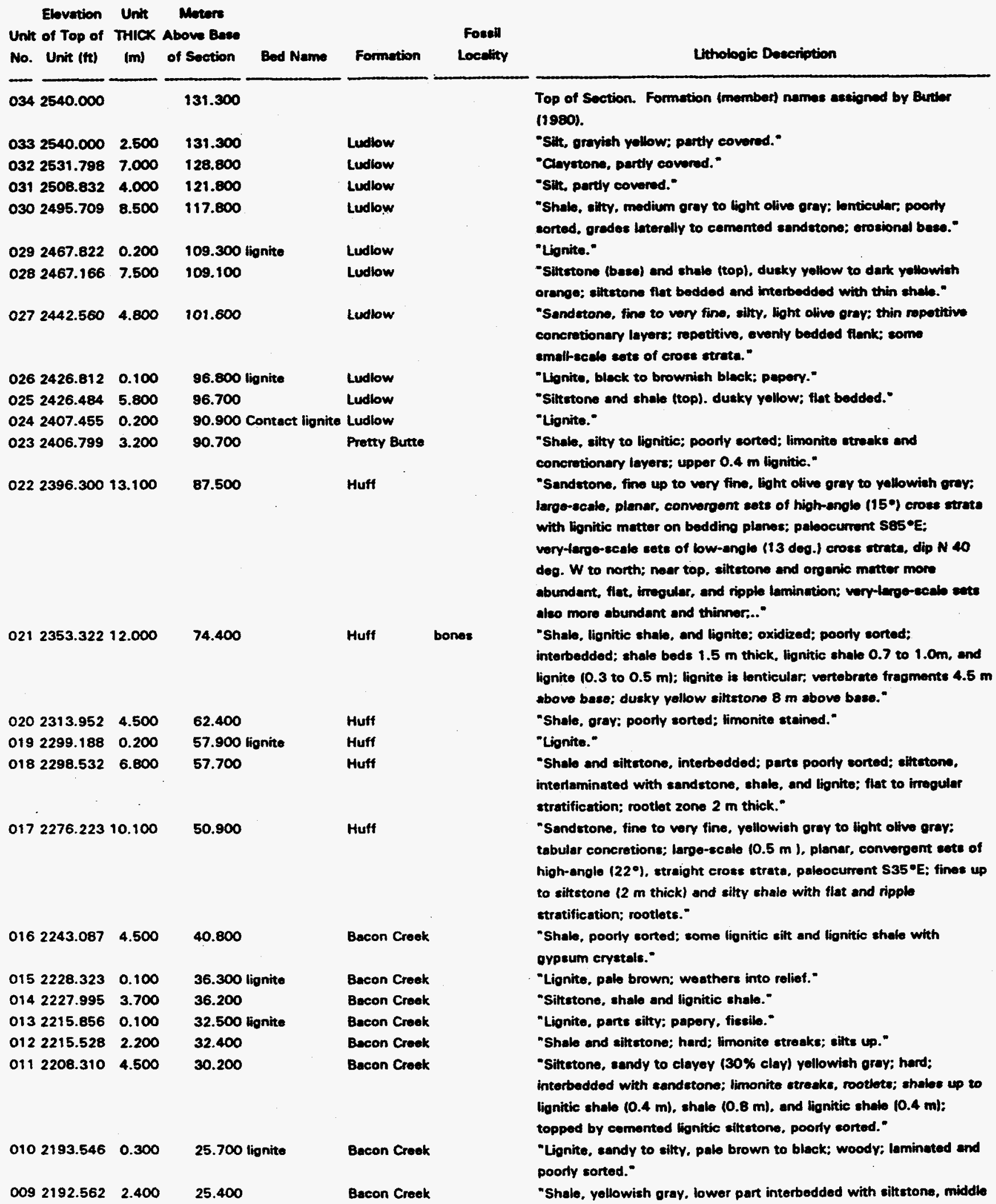




\section{Measured Section M3724 (Butler, 1980, Section CC3) \\ (Elevations given in feet for use with topographic quadrangle)}

\begin{tabular}{|c|c|c|c|c|}
\hline $\begin{array}{l}\text { Elovetion } \\
\text { Unit of Top of } \\
\text { No. Unit (tt) }\end{array}$ & $\begin{array}{c}\text { Unit } \\
\text { THICK } \\
\text { (m) }\end{array}$ & $\begin{array}{l}\text { Moters } \\
\text { Above Bese } \\
\text { of Section }\end{array}$ & Bad Name & Formation \\
\hline 0082184.688 & 2.200 & 23.000 & & Becon Creak \\
\hline 0072177.470 & 1.500 & 20.800 & & Becon Creok \\
\hline 0062172.549 & 1.600 & 19.300 & & Bacon Creok \\
\hline 0052167.300 & 0.300 & 17.700 & ignite & Bacon Creok \\
\hline 0042166.316 & 3.900 & 17.400 & & Bacon Creok \\
\hline 0032153.521 & 0.600 & 13.500 & lionite & Bacon Croek \\
\hline 0022151.553 & 0.900 & 12.900 & & Marmarth? \\
\hline 0012148.600 & 12.000 & 12.000 & & Marmsith? \\
\hline 2002109.230 & 0.000 & 0.000 & & \\
\hline
\end{tabular}

\section{Foseil}

Loeality

Intholooic Description

pert bertonitic, end upper pert lignitic.

-Shle, yellowish orey; lower part interbedded with eittetone, middle part bentonitic. upper part elightly banitic."

"Shate, upper part efighty bonitic."

"Sitstone and silty shale, yellowish grey; cemented to looschy consolideted."

"Lionite. pele brown to bleck."

-Sitmone, ahele, and lignitic shale; aitutone is $1.5 \mathrm{~m}$ thick. interbedded with very fine sandetone; shole is olive oray: oweral poofly sorted, flatly stratified, rootlets, erosional bese."

"Lianite, brown to black."

"Shale and lignitic shale."

"Sandstone, fine to medium, cleyey (top); yellowish grav: fines upward; large-scale 10.1 to $0.5 \mathrm{ml}$. orouped. plenar sets of hiph-angle straight, tangential cross strats and imeguler eats of otraight to concave crose strate. paleocurrent $515^{\bullet} \mathrm{W}$; pyrite nodules at $6 \mathrm{~m}$ above base; very clayey at $12 \mathrm{~m}$."

Base of tection "Measured cection CC3 - T. 15 N., R. 55 E., Sec. 1. NE quarter of SE quarter." Section measured by Butior (1980): location determined from unpublished field map (R.D. Buther, pers. camm.). The base and top of Section CC3 were given as 2110 ft to $2450 \mathrm{tt}$, respectively, representing a thickness of $340 \mathrm{tt}$. The elevations given in this here represent Butlor's given section thicknese. The top elevation was estimnted et $2540 \mathrm{ft}$ to conform to the given section thicknoss, with the bese minimized. 


\section{Measured Section M4376 (Hiatt Section) (Elevations given in feet for use with topographic quadranglel}

\begin{tabular}{l}
$\begin{array}{l}\text { Elevation Unit Moters } \\
\text { Unit of Top of THICK Above Bese }\end{array}$ \\
No. Unit (ft) (m) of Section Bed Name Formation Locellty Samplo No. \\
\hline 0362525.727
\end{tabular}

$\begin{array}{lllll}0352525.727 & 10.000 & 113.000 & \text { Ludlow } \\ 0342492.919 & 0.600 & 103.000 & \text { Ludlow } \\ 0332491.279 & 3.400 & 102.500 & \text { Ludlow } \\ 0322480.124 & 8.000 & 99.100 & \text { Ludlow }\end{array}$

0312453.87825 .000

91.100

Ludlow

$0302371.858 \quad 1.000$

66.100

Ludiow

$\mathbf{L 5 4 1 8}$
65.100

64.600

64.000

61.000

60.900 unnamed Ludlow lionite

60.650

Ludlow
Ludlow

Ludlow

Ludlaw
$0232335.607 \quad 0.250$

$0222334.787 \quad 0.150$

$0212334.295 \quad 0.200$

$\mathbf{5 4 . 4 5 0}$

0192333.3110 .100
54.650

54.350

55.050 Contact lignite Ludlow

Hell Creok

Hell Creok

Hell Croek

Hell Creak

\begin{tabular}{|c|c|c|c|}
\hline 0292368.577 & 0.500 & 65.100 & Ludlow \\
\hline 0282366.937 & 0.600 & 64.600 & Ludlow \\
\hline 0272364.969 & 3.000 & 64.000 & Ludlow \\
\hline 0262355.127 & 0.100 & 61.000 & Ludlow \\
\hline 0252354.799 & 0.250 & $\begin{array}{c}60.900 \text { unnamed } \\
\text { lignite }\end{array}$ & Ludlow \\
\hline 0242353.979 & 5.600 & 60.650 & Ludlow \\
\hline
\end{tabular}

abvBTetovimi.MS-bod-Im-loce-AUNIT.DTF

12/23/95, 4:60 pen, p. 1

No.

To

Top of section has a surveyed elevation of $2510 \mathrm{ft}$. Acsuming a greater thicknese for the esction than the oveilsbie clevetion (becase of variable thick chamel eandatones), the top of the section will renoe to 2525 th. so that the bese moy etert at $2155 \mathrm{ft}$. This better pleces the Hiatt Locelity elovetion se determined throuph use of the topographic quedrenglo.

Covered to top.

Cleystone, carbonsceous; fiesile; boht brownish orey 6 YR 6/1I.

Cleyetone, sitty: organic fregmente on planer bedding: lioht brownish grey (5 YR 6/1).

Siltetone, ettemating with plener bedded silty cloystone. with emall seale ripples in the citzetone and mutiple discontinuous concretionary layers: moderate yollowish brown (10 YR 5/4).

Sendstone, fine-grained, with salt and pepper aurfece eppearance; ripply trowh cross-bedded, numerous resctivated surfaces, and intreclantic conglomernte layors; yollowith gray 15 Y $7 / 21$.

Sandstone, fino-grained, with salt and popper surtece appearance; larve-ecele crose-bedding in lowermost portion of unit, horizontally bedded above $1 \mathrm{~m}$; vellowish arey (5 Y 7/2), duety yellow (5 Y 6/4) in querry. whth a moderate brown (5 YR 3/4) color on plener curfeces; Hiatt locality (L5418) 10 to $1.0 \mathrm{~m}$ ).

Lignite.

Covered.

Clayetons, silty, fiesile; not rooted, very thtle plant dabris; moderate yellowiṣth brown (10 YA 4/2).

Cloystone, carboneceous: pale vellowish brown $110 \mathrm{YR}$ 6/21.

Lienite.

Sandstone, very fine-grained, with satt and pepper appearance, with some wall lithitiod benes, trough crose bedded: moderate yellowish brown surface $110 \mathrm{YR} 5 / 41$. with some elaystone layers of a vory light gray (N 8) (fresh).

Lithic Lignite (Contact lignite of Sholes and others, 1989). This eample lignite was previously sampled by Pack and Hartman in July 1990.

Lithic Claystone, roote and plants, with slickensfides; olive bleck sample (5 Y 2/11). Unit previousiy sampled for pollon by Puck and Hartman in July 1990.

Pollen 5 Claystone, roots and plants, with eliekenatides; olive bieck (5 Y 2/1). Pollen sample 5 taken $0.5 \mathrm{~m}$ to $0.7 \mathrm{~m}$ abowe base of Unit 18.

Claystons: roots and plants. with slickenslides; olive bleck (5 Y $2 / 1)$.

Pollen 4 Claystone; roots and plants, with slickenslidas; olive black (5 Y 2/1). Pollen Sample 4 taken $0.3 \mathrm{~m}$ to $0.4 \mathrm{~m}$ above 


\section{Measured Section M4376 (Hiatt Section) (Elevations given in feet for use with topographic quadrangle)}

\begin{tabular}{|c|c|c|c|c|c|c|c|}
\hline $\begin{array}{l}\text { Elovetion } \\
\text { Unit of Top of } \\
\text { No. Unit (ft) }\end{array}$ & $\begin{array}{l}\text { Unit } \\
\text { MHCX } \\
\text { (m) }\end{array}$ & $\begin{array}{l}\text { Metor } \\
\text { Abow Boes } \\
\text { of Soction }\end{array}$ & Bed Name & Fomntion & $\begin{array}{l}\text { Fossil } \\
\text { Localiny }\end{array}$ & $\begin{array}{l}\text { Roek } \\
\text { Sample No. }\end{array}$ & Lithologic Description \\
\hline 0182332.983 & 0.300 & 54.250 & & Hell Croek & & & $\begin{array}{l}\text { bece of Unit } 18 . \\
\text { Clavetone; roote and plente. with elietendides; oliw blect } \\
\text { (5 Y } 2 / 11 \text {. }\end{array}$ \\
\hline 0172331.999 & 2.800 & 53.950 & . & Hell Creek & & Pollon 3 & $\begin{array}{l}\text { Sandstone, clayey and silky very fine-grained lcoence } \\
\text { mudetone): rooted; about dusky yollow (5 Y } 6 / 4) \text { to } \\
\text { yellowish grey (5 Y } 7 / 2) \text {. Pollen Semple } 3 \text { taken } 2.5 \mathrm{~m} \\
\text { above bese of unit. }\end{array}$ \\
\hline 0162322.813 & 10.800 & 51.150 & & Hell Creak & & & 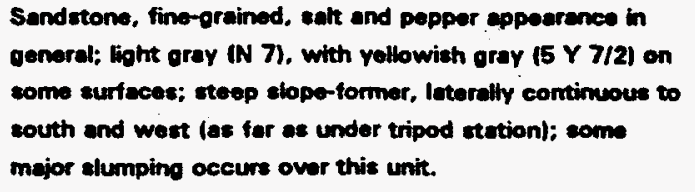 \\
\hline 0152287.380 & 1.900 & 40.350 & & Hell Creok & & Pollon 1-2 & $\begin{array}{l}\text { Clayetone, silty: root treces and orvenic debris obundemt: } \\
\text { fight olive oray }(5 \text { Y } 5 / 2 \text { ), with rusty brown sandetene } \\
\text { concretions. Pollen Semples } 1 \text { and } 2 \text { were taken at } 0.5 \\
\text { and } 1.25 \mathrm{~m} \text { above the base of unit. }\end{array}$ \\
\hline 0142281.146 & 1.500 & 39.450 & & Hell Creek & & & $\begin{array}{l}\text { Sittstone. stightly clayey: root traces. planar bedded: } \\
\text { yellowish gray ( } 5 \text { Y } 7 / 2)\end{array}$ \\
\hline 0132276.225 & 2.000 & 36.950 & & Hell Creek & & & $\begin{array}{l}\text { Cleystone, slightly wilty; root traces and plant fragments, } \\
\text { bench former in part; light olive grey }(5 \times 5 / 2)\end{array}$ \\
\hline 0122269.663 & 7.000 & 34.950 & & Hell Creak & & & 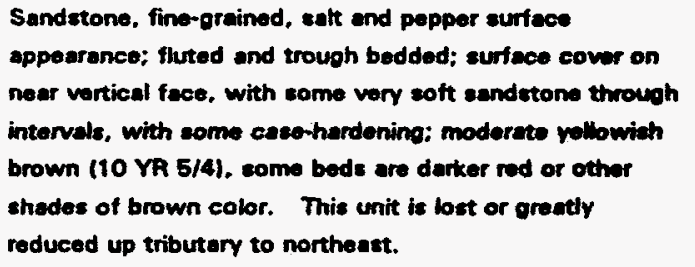 \\
\hline 0112246.697 & 3.000 & 27.950 & & Hell Creek & & & 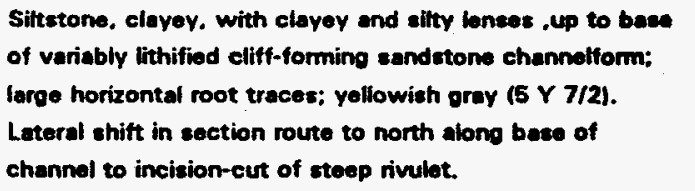 \\
\hline 0102236.855 & 1.700 & 24.950 & & Hell Creek & & & $\begin{array}{l}\text { Claytone, cabonaceous silty: laminated, no root treces. } \\
\text { plant tragments, including laroe vitreous tragments; pals } \\
\text { yollowish brown }(10 \mathrm{YR} 6 / 2) \text { with darker shedes. Unit is } \\
\text { probably lecustrine. }\end{array}$ \\
\hline 0092231.278 & 1.100 & 23.250 & & Hell Craak & & & $\begin{array}{l}\text { Siltetone, clayey: abundant rootc. with disseciated } \\
\text { surface; yellowish oray }(5 \text { Y } 8 / 1) \text {. }\end{array}$ \\
\hline 0082227.669 & 6.000 & 22.150 & & Hell Creek & & & $\begin{array}{l}\text { Sandstone, very fine-grained, salt and pepper appearance; } \\
\text { trough bedded with cemented pods, otherwise friable; } \\
\text { trend of } 11^{\circ} \text { on small ripples in concretions; concretions } \\
\text { common, with some fining-upwards evidert; color difficutt } \\
\text { to assess, basically light gray (N 7); concretions variable } \\
\text { color grayish brown (5 YR } 3 / 2 \text { ). }\end{array}$ \\
\hline 0072207.984 & 2.900 & 16.150 & & Hell Creok & & & $\begin{array}{l}\text { Clayetone, with bands of silty claystone and clayey } \\
\text { siltstone; without bedding; verticel and horizontal roots; } \\
\text { yellowith oray (5 Y } 7 / 2 \text { ) (eitry) to light olive oray (5 Y } 6 / 1 \text { ) } \\
\text { (clayey). }\end{array}$ \\
\hline 0062198.470 & 1.400 & 13.250 & & Hell Creok & & & $\begin{array}{l}\text { Sandstone. finge-grained, slightly claver, variegated. } \\
\text { cross-stratified; with vertical roots; yellowiah gray }(5 . \text { Y } \\
7 / 2) \text { and come light olive oroy }(5 \text { Y } 5 / 2) \text {. }\end{array}$ \\
\hline 2193.877 & 2.600 & 11.850 & & Hell Creok & & & Siltstone, clayey: abundant roots, desiccated surfece; \\
\hline
\end{tabular}


Measured Section M4376 (Hiatt Section)

(Elevations given in feet for use with topographic quadrangle)

Elovotion Unit Meters

Unit of Top of FHCK Abom Bnes

No. Unit (it)

(m) of Section

Bed Name Formation

Foneti

Rock

$\longrightarrow$

$0042185.347 \quad 0.600$

9.250

Hell Crook

$0032183.379 \quad 1.050$

8.650

Holl Creek

$0022179.934 \quad 0.400$

7.600

Holl Croek

$0012178.622 \quad 7.200$

7.200

Holl Creek

$0002155.000 \quad 0.000$

0.000

ebvBT TovimI.MS-bod-Im-10a-AUNIT.OTF

12/23/95, 4:60 pm, p. 3

dusky yellow (5 Y 6/4).

Siltetons, cleyey, wery blocky, but lamineted in part plent hesh abundant: a laterally discontinuous lodge fonmer. pale vollowish brown (10 YR 6/2).

Claystone. silkty, very thin silky layers (lenees) common: plent hash abundant and horizontal root treces common $(0.5 \mathrm{~cm})$; tiont olive oray $(5 Y 5 / 2)$.

Sandetone, vary firse-grained, omall ripple laminated, lodoe-former; moderate yollowith brown (10 YR 5/4). wathered (dry) dunky yellow (5 Y 6/4).

Sitstone, clayey; contains variable amounte of claystones and siltetones; banded fissile, clean, atickenside-bearing. with desiccated surfece, abundant root treces, end plent parts; dutky yollowish brown cloytone to yollowish gray (5 $Y 7 / 2)$ to light olive oray 15 Y 5/2).

Base of section. 


\section{Measured Section M4769a (Muddy Tork Section) (Elevations given in feet for use with topographic quadrangle)}

\begin{tabular}{|c|c|c|c|c|c|}
\hline $\begin{array}{l}\text { Unit } \\
\text { No. }\end{array}$ & $\begin{array}{l}\text { Elevetion } \\
\text { of Top of } \\
\text { Unit (ft) }\end{array}$ & $\begin{array}{c}\text { Unit } \\
\text { THICK } \\
\text { (m) }\end{array}$ & $\begin{array}{l}\text { Motar } \\
\text { Above Base } \\
\text { of Soction }\end{array}$ & Bed Neme & Formation \\
\hline 024 & 2267.807 & 0.000 & 48.100 & & \\
\hline 023 & 2267.807 & 1.500 & 48.100 & $\begin{array}{l}\text { Witches Hat } \\
\text { Sandstone }\end{array}$ & Hell Creek \\
\hline 022 & 2262.886 & 4.200 & 46.600 & & Hell Creak \\
\hline 21 & 2249.107 & 0.400 & 42.400 & & Hell Creek \\
\hline 020 & 2247.795 & 3.150 & 42.000 & & Holl Creek \\
\hline
\end{tabular}

38.850

36.150

34.900

34.000

31.500

31.350

30.600

30.000

27.800

0112201.2073 .700

0102189.0683 .400

24.100

Hell Creek bones

0092177.9135 .400

Hell Creek bones
Lithologic Deseription

Top of section at locel top of enst-west ridge. Sandstone, terge scab trough crose beds: large claybell cenention occurs $3 \mathrm{~m}$ above base of sandstone unit; menty yellowish orey (5 Y 7/2) and sliantly derker ahodes. This is the sandstone body thet forms part of Witches Hat. Locality 26205 (WB92-15) is in the lowermost portion of this unit, with sampling about $3 \mathrm{~m}$ below beal top of the measured section and ridoe.

Siltstone, clayoy, with some interbedded orenic rich horizons: yellowish gray 15 Y $7 / 21$ : eurfece of unit has bone meterial. which is derived from overlying unit.

Sitstone, clayey well laminated, abundant organic debris: dark yollowith brown (10 YR 4/2).

Sitstone. clayey. in upper and lower thirds and a silty clayetone in the middle thind; the oradations between these two kthoboive ene indistinguichable: root traces occur in upper third of the unit: the color in the lower and upper thirds of the unit is yellowish gray $15 \mathrm{Y}$ 7/2). while the middle third is light olive oray (5 Y 6/1).

Siketone, slightly clayey, oreding upwerd into clayey eltetons: moderate yollowish brown (fO YR 5/4); resistant ironstono concretion layer at top of unit (present only bockly).

Sandstono, very fine-orainod, fining upward to a slightly cloyey sittstone; some organic material present on bedding surfeces: bedding includes plener and emall scale cross bedding; light olive gray $(5 Y 5 / 2)$.

Siltetone. clayey; between dask yellowish brown $(10 \mathrm{YR} 4 / 2)$ and dusky yollowish brown (10 YR 2/2).

Sittetone, slightiy andy. eppears to fine upwerds, with the lower partion boing a slightly sitty, very fine-grained sandetone, with some root traces in upper portion: noafly light olive orey (5 Y 5/2).

Claystone, sitty; dusky yellowish brown (10 YR 2/2).

Sitetone, clayev, planar laminated, with abundant coalified orgenic debris on the laminae; dark yollowish brown (10 YR 4/2).

Claystone, slightly sitty, with some pedopenic slickenaides; nearty olive oray (5 Y $4 / 1$ ), and brown black $(5$ YR $2 / 1 /$ in upper $10 \mathrm{~cm}$. Silstone. clayey, with clay content increasing towerds the top; loht olive gray (5 Y 5/2).

Claystones, silty. and clayey siltetones, deeply waethered; this unit appears to be somewhat more organic rich in the upper $0.5 \mathrm{~m}$; light olive oray (5 Y 5/2) in lower part, dark yollowish brown (10 YR 4/2) in upper part.

Sandstone, fine-grained sandstone, with organic rich silty sendstone layers; planar bedding and small scalo cross-bodding; indistinct upper contact; the color is slightly darker than yellowish gray (5 Y 7/2). Bone fragments appear to be weathering out of the bese of this unit. Sandstone, sitty, interbedded with clayey sendy siltstone, plenar bedded in most pleces, with organic debrit on bedding plenes; come root traces noted in upper portion of unit: the color is alightly darter than yellowish gray (5 $>7 / 2)$. Reptilien/?] remains (bone fragmente) strown about surface.

Clayatone, silty; some root traces; light olive oray $(5$ Y 5/2), derker at the top of the unit indicating greater organic content; the upper portion of unit is nearty olive black $(5 \vee 2 / 1)$. 


\section{Measured Section M4769a (Muddy Tork Section) \\ (Elevations given in feet for use with topographic quadrangie)}

\begin{tabular}{|c|c|c|c|c|c|}
\hline $\begin{array}{l}\text { Unit } \\
\text { No. }\end{array}$ & $\begin{array}{l}\text { Elovation } \\
\text { of Top of } \\
\text { Unit (tt) }\end{array}$ & $\begin{array}{c}\text { Unit } \\
\text { THICK } \\
\text { (m) }\end{array}$ & $\begin{array}{c}\text { Metere } \\
\text { Above Bese } \\
\text { of Section }\end{array}$ & Bed Name & Formation \\
\hline$\infty$ & 2153.143 & 1.100 & 13.150 & & Holl Creek \\
\hline$\infty 06$ & 2149.534 & 0.900 & 12.050 & & Hell Crook \\
\hline 005 & 2146.581 & 0.400 & 11.150 & & Holl Creok \\
\hline$\infty$ & 2145.269 & 1.300 & 10.750 & & Hell Croek \\
\hline$\infty 03$ & 2141.004 & 0.750 & 9.450 & 'isitor bed & Hell Creok \\
\hline 002 & 2138.543 & 0.500 & 8.700 & & Hell Creok \\
\hline 001 & 2136.903 & 8.200 & 8.200 & & Hell Croek \\
\hline 00 & 2110.00 & 0.000 & 0.000 & & \\
\hline
\end{tabular}

\section{Foseil}

Locetiny
Uthologic Description

Cleyetone. sitty, lignitic etringers: upper $10 \mathrm{~cm}$ is wery orgenic tich. with abundent plant tragments: the color is between duaky yellowish brown (10 YR 2/2) and brownish gray $15 \mathrm{Y} 4 / 11$, with the uppormost portion a pale brown (5 YR 5/2) in color.

Caystone, silty, smoctitic, some root treces; forms o popeom eppearance when weathered; bight olive oroy (5 Y 6/I).

Cloystone, silty, to clayey sittutone, with common plont fregments and root traces: color is between olive gray $(5$ Y $4 / 11)$ and bight olive gray (5 Y 6/1).

Sittetone, clayey, with root treces and plant treaments throughout the unit: fairly sharp upper contact; yellowish gray 15 Y $7 / 21$. Siltatone, clayey, orgenic rich: brownish bleck 5 YA 2/1). This unt is an extenaive treceable unit in this ares (Rob Kukowati's lignite). Sitstone, sendy, with root traces: light ollive oray (5 Y 6/1). Sendetone, fino-grained, large scelo trough crose-beds; unit is rilled, and a eliff former, concontration of orgenic debris on come of the larpe seale trough cross beds; uppermost portion of unit has root traces: color is dusky yellow $(5 Y 6 / 4)$ to yollowish gray $(5 \vee 7 / 2)$. Bace of eaction on pediment flats next to the Weleome sion at the entrance to Makoahike State Park lat park boundaryl. 
Measured Section M4769b (Witches Hat Section)

(Elevations given in feet for use with topographic quadrangle)

Elovetion Unit Moters

Unit of Top of THiCK Above Bese

No. Unit ( $f$ ) (m) of Section Bed Name Formetion Lithologic Deseription

$0032354.5840 .000 \quad 26.450 \quad$ Top of section ef top of Witches Het

$0022354.5843 .500 \quad 26.450$ Witches Hat Hell Creok Clovetone. silty. smectitic. 3.0 to 4.0 moters to top of het. This unit coud not be Sandetone $\quad$ examined in frech exposure due to the precipitous neture of the exposure.

0012343.10122 .950 22.950 Witches Hat Hell Creek

Sendstone, large scele trough crose beds; scoured bese thickening local section.

$0002267.807 \quad 0.000$ 0.000

Base of section is local bese of Witches Hat Sendstone at Witches Hat. 


\section{Measured Section M4770 (Fern Spike Section) (Elevations given in feet for use with topographic quadrangle)}

OAd Elovetion Unit Moters Unit Unit of Top of MHICK Abow Bace No. Unit (ft) (m) of Soction $\begin{array}{lll}040020 \quad 2450.000 & 24,900\end{array}$ $0390192450.0003 .000 \quad 24.900$

\author{
$038018 \quad 2440.158 \quad 3.000$
}

21.900

Ludlow

$0370172430.316 \quad 3.800$

18.900

Ludlow

0360162417.8493 .000

15.100

Ludlow

$035015 \quad 2408.0070 .100$

12.100

0340142407.6790 .200

12.000

Ludlow

Ludlow

0330132407.0232 .350

11.800

Ludiow

$032012 \quad 2399.3130 .500$

$0310112397.673 \quad 0.400$

$030010 \quad 2396.3610 .350$

0290092395.2130 .150

028008 c 2394.721 0.050

$027008 b 2394.5570 .100$

026008 a 2394.2290 .100

8.000

7.900

8.200

8.050

Ludlow

Ludiow

$0.15 \mathrm{~cm}$

$20-25 \mathrm{~cm}$

$025007 \quad 2393.901 \quad 1.950$

7.800

5.850

Ludiow
Pock Semple No.
Lithologic Description

Top of section.

Covered unit to top-most of ridge surfece. Photos taken towerds Hintt Lecality from northom portion of ridge. This viow clearly showe masured Section M4376 lon bearing of $65 \%$. more or less directly ower rithe range. The route of lest yeer's use of a fromt-end loeder is clanty vieible.

Sendetone (continued), beally bess wellthithified, but leterelly with ledges and eaprock; pabocurrent direction is to east at cbout $130^{\circ}$

Sandstone, wall lithitied, channelform, lerge-scale trough enose bedding. forms bodges and ceprock locelly feame thobloey as underfying unit minus orange stringerel. Surfece weothered color is moderate yellowich brown $(10$ VR $5 / 4)$ to derk yellowith orange (10 YR 6/6) (various photos taken).

Sandstone, fine-orained, with some medium-orained clasts; approximately yollowish gray (5 Y 8/1), with numerous thin orange leyers about greyish orange (10 YR 7/4): forms a weathered surface with a bright refiectance. Lignite, poor, to carbonsceous shale; probsbly discontinuous. Claystone, with coaly etringers up to $3 \mathrm{~cm}$ thick and cosly dabrie on surfaces of lemines: "chocolate brown," pele yellowich brown (10 YA 6/2) to pale brown (5 YR 6/2).

Siltetone, clayoy, but forming hesvily weathered slope, bendad with oxidized layere of orenge and greve and topt browns. Unit forms a diseceted surface typical of this litholooy.

Claystone, well laminated, plant rich; mottled palo yollowith brown (10 YR 6/2).

Claystone, with plent etems; light olive gray (5 Y 5/2). Shale, paper, slightly silty: black (N 1): oreding up into claystone, fisetib, but not papor shable ldoes not break into sheete). gravish brown (5 YR 3/2). but varying in color. Lignite. Sample taken for pollen enalyais.

Clavetone fuppermost portion of Whic Units 26-28). irregulerly badded, root traces, dusky yellowich brown (10 YR 2/2). Sample for pollen analysis taken $20-25 \mathrm{~cm}$ abowe the bese of unit.

Cloystone, Iaminated (see Unit 26).

Claystone, laminated, in lower portion of unit, with wood fragments. fow root traces; variable color due to organic content, ranges from moderate brown (5 YR 3/4) to a pele Yollowith brown (10 YR 6/2) (the latter is a more weathered colorl. with bleck organic tragments. Uppermost portion is cleystone, irregularly bedded, root traces, duaky yellowish brown (10 YR 2/2). Samples for pollen analysis taken $0-10 \mathrm{~cm}$ and $20-25 \mathrm{~cm}$ above the base. Total thickness of Unit $26-28$ is 0.25

Sittstono, coarse, to very fino-oreined sandstone, orading upwerds to clayey siltstone to slightly clayey altetone; bwer part is oranular and friable, and yellowiah gray (5 $Y 7 / 2)$; upper part is about ducky yellow (weathered?) 15 Y 6/4). Claystone, slightly siky (see Unit 23). Top of unit marked by oxidized limonitic concretionary chips. 


\section{Measured Section M4770 (Fern Spike Section) (Elevations given in feet for use with topographic quadrangle)}

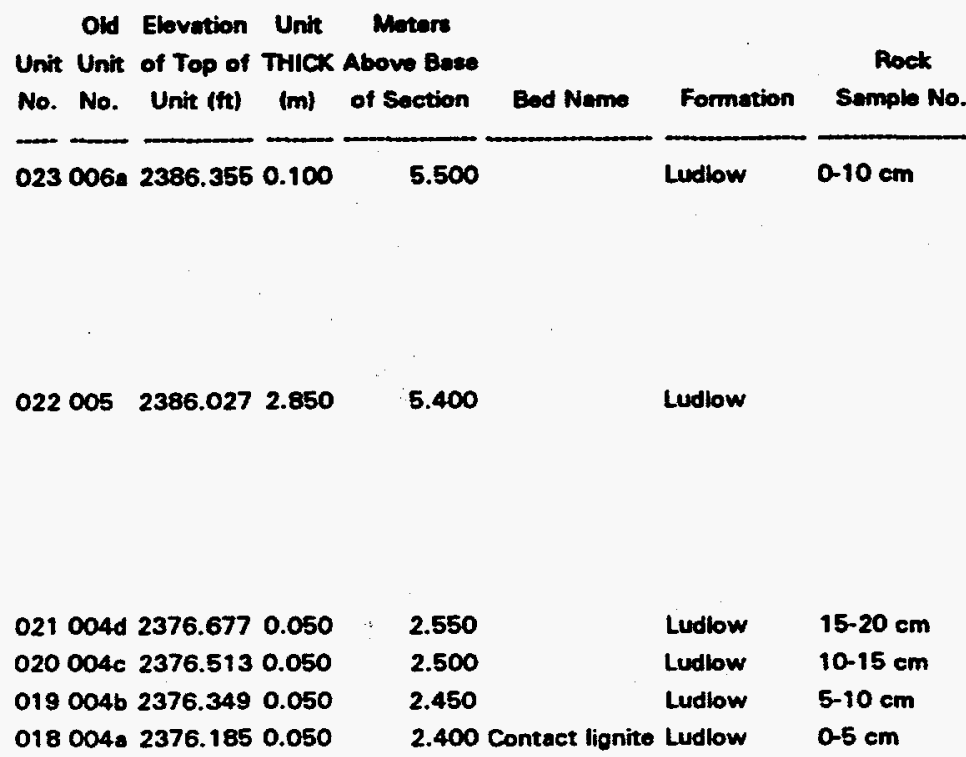

$017003 d 2376.0210 .050$

$016003 c 2375.8570 .050$

01500362375.6930 .050 014003 a 2375.5290 .050
Hell Creak

Hell Crook Hell Creok

Hell Creek Hell Creek

Hell Creek Hell Creak
145-155 cm

$80-90 \mathrm{~cm}$

$40-50 \mathrm{~cm}$

$0.20 \mathrm{~cm}$
Luthologic Deseription

Claystore, sliphtly silty. more silty towarde the top, leminated.

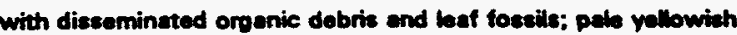
brown (10 YR 6/2) with yellowish aray 15 Y $7 / 2$ ). Semplo for pollon analysis taken from $0-10 \mathrm{~cm}$ above base. Totel thicknese of Units 23 and 24 is $0.45 \mathrm{~m}$. [Procesesed - Pabocens palynomorphs.1

Sittutone, elighthy clayey, well laminatod, orgenic debris on bodding planes; light olive gray $(5$ Y 6/1) to, and may be predominently, yellowiah oray (5 Y 7/2): varioguted oxidized orenge bends; browns orede into oraye; topped by clayetone (ebout $20 \mathrm{~cm}$ thick), wery light gray to gray $(N \mathrm{~N}-\mathrm{N} 7)$. On wery steop and westhered clitf (dangerous to measurel.

Lignite (see Unit 18). [Processed - Pabocens polynomorphe.] Lianite (eoo Unit 18). (Procesesed - Palooceno palynomorphs.] Lignite (soe Unit 18). [Processed - Poloocene palynomorphe.] Lignite, plant rich (Contact Coel of Sholes and othere, 1989). Samples for pollen analysiz taken overy $5 \mathrm{~cm}$ through unit. Total thickness of unit 18-21 is $0.20 \mathrm{~m}$. (Proceseed - Peloocente palynomorphs.]

Siltetone, clayey, or silty clayetone (6ee Unit 14). Samples for pollon analysis taken from $15-20 \mathrm{~cm}$ above the base of unte. [Processed - includes fom spike indicating lowermost Peleoceno.] Sittetone, eloyey, or eilty claystone (2000 Unit 14). Semple for pollen analyaie taken from $10-15 \mathrm{~cm}$ above the bese of unit. [Processeed - Creteceous palynomorphs.]

Siltatone, clayey, or silty clayetone (see Unit 14).

Sitstone. cloyey, of silty claystone, coarzening upward from clayey to silty; root traces throughout, pedogenic alickensides in lower part. more leminated above; lower color mottled brownish black (5 YR 2/1) with alive black (5 Y 2/1) and fighter colors: upper color is pale yellowish brown (10 YR 6/2): Samples for pollen analysis taken from $0-5 \mathrm{~cm}, 10-15 \mathrm{~cm}$, and $15-20 \mathrm{~cm}$ above the base. Total thickness of Units 14-17 is $0.20 \mathrm{~m}$. [Processed - Cretaceous palynomorphs.] Siltstone, clayey (soe Unit 7). Sample taken for pollen analysis from 145-155 cm above the base of unit.

Siltstone, clayey, laminated (soe unit 7 ).

Siltstone, clayey (see unit 7). Sample taken for pollen analyais from $80-90 \mathrm{~cm}$ above the base of unit.

Sitstone, cloyey (see Unit 7).

Siltetone, clayey (see Unit 7). Sample taken for pollon enalysis from $40-50 \mathrm{~cm}$ above base of unit. [Processed - Crataceous palynomorphs.l

Sittstone, clayey (see Unit 7).

Sitztone, clayoy. fining upward to a silty clayetone, and to a stightly sity claystone at top; leminated, some root traces and some plant freoments. more bioturbated toward top; variegated color (difficult to classify), pale yellowish brown (10 YR 6/2) to brownish black? (5 Y 2/1). Samples taken for pollen enalyais from 0-20 cm, 40-50 cm, 80-90 cm, and $145-155 \mathrm{~cm}$ above the base. Total thickness of Units 7.13 is $1.55 \mathrm{~m}$. Silstone, clayey (see Unit 1). Sample for polien analysis taken 
Measured Section M4770 (Fern Spike Section)

(Elevations given in feet for use with topographic quadrangle)

Old Elevetion Unit Meter: Unit Unit of Top of THICK Abov Base No. No. Unit (ft) (m) of Section Bed Nam Formation Sample No.

No. No. Unit (ft) (m)

005001 e 2369.9530 .100 $004001 d 2369.6250 .100$

0.500

0.400

$003001 c 2369.2970 .150$

$002001 \mathrm{~b} 2368.8050 .050$

0.300

0.150

Hell Croek

Hell Croek
0.100

Co1 Co1a 2368.6410 .100

$000000 \quad 2368.3130 .000$
0.000 Uthologic Desecription

\section{Rock}

from $50-60 \mathrm{~cm}$ sbove base of unit.

Siltotone, cloyey lsee Unit 11.

Sitstone, cloyey leee Unit 1). Sample for pollen enatyis taken from $30-40 \mathrm{~cm}$ above base of unit.

Sittetone, clayey (eec Unit 11 .

Hell Creok $10-15 \mathrm{~cm}$

Siltetone, clavey fese Unit 11, Sample for polien analyais teken at $10-15 \mathrm{~cm}$ above base of unit. IProcessed - Creteceous pelynomorphe.1

Sittrtons, clavey, with thin lemines of elaystone and root treces: lese sitt and fewer root treces towards top; few mecroplent remains; organic rich colot, orayish black (N 2) to dark yollowich brown (10 YR 4/2). Samples for pollan analyais taken from $10-15 \mathrm{~cm}, 30-40 \mathrm{~cm}$, and $50-60 \mathrm{~cm}$ above the base of unit. Total thickness of Units $1-6$ is $0.60 \mathrm{~m}$.

Base of section. Contact Coal Section No. 1. Southwest-fecing stoep exposure below orassed-topped ridoe, bated eoutheast of Wrehes Hat lbut on ridge north of the ridge beering Witches Hat), southwest of terred park road, south of Ceine Coules. Section base is on a bearing of $320^{\circ}$ with the Witches Hat. Section begins above chansel sandstone corrolative with the Witches Hat Sandetone. 
Measured Section M4771 (K/T Boundary Section)

(Elevations given in feet for use with topographic quadrangle)

Old Elovation Unit Motere

Unit Unit of Top of THICK Above Base

No. No. Unit (ft) (m) of Section Bod Name Formation Sample No.

$024007 \quad 2333.003 \quad 7.620$

0230062333.0034 .000

7.620

Ludiow

022005 c 2319.8800 .050

$021005 b 2319.7160 .050$

020005 a 2319.5520 .050

3.620 Contect lignite Ludlow 3.570 Contect Hignite Ludlow 3.520 Contact lignite Ludlow

$10-15 \mathrm{~cm}$ $5-10 \mathrm{~cm}$ $0.5 \mathrm{~cm}$

$019004 b \quad 2319.3880 .040$

3.470

01800482319.2570 .030

3.430

Mell Creok $\quad 3.7 \mathrm{~cm}$

Mell Creek $\quad 0.3 \mathrm{~cm}$

$0170030 \quad 2319.1590 .050$ $016003 n \quad 2318.9950 .050$

3.400

3.350

3.300

3.250

3.200

3.150

3.100

3.050

3.000

2.950

2.900

2.850

2.800

2.750

2.700

003003 a 2316.863 0.050

$002002 \quad 2316.699 \quad 1.650$

2.650

Hell Croek

$001001 \quad 2311.2861 .000$

1.000

Hell Crook
Hell Creek Hell Creok Hell Creok Holl Creok Hell Creok Mell Croek Hell Crosk Mell Croek Holl Creek Hell Creek Holl Croek Hell Crook Hell Creok Heil Crook Hell Croek

$70.75 \mathrm{~cm}$ $65.70 \mathrm{~cm}$ $60-65 \mathrm{~cm}$ $55.60 \mathrm{~cm}$ $50-55 \mathrm{~cm}$ $45-50 \mathrm{~cm}$ $40.45 \mathrm{~cm}$ $35-40 \mathrm{~cm}$ $30.35 \mathrm{~cm}$ $25-30 \mathrm{~cm}$ $20-25 \mathrm{~cm}$ $15.20 \mathrm{~cm}$ $10-15 \mathrm{~cm}$ $5.10 \mathrm{~cm}$ $0.5 \mathrm{~cm}$

$000000 \quad 2308.005 \quad 0.000 \quad 0.000$

cbVBTohy(m),MS-oldU-bed-fm-rke-AUNIT.DTF

12/26/95, 0:49 pm, p, 1 


\section{Measured Section M6723 (First P-Mag Section) (Elevations given in feet for use with topographic quadrangle)}

\begin{tabular}{|c|c|c|c|c|c|c|}
\hline $\begin{array}{l}\text { Elovation } \\
\text { Unit of Top of } \\
\text { No. Unit (ft) }\end{array}$ & $\begin{array}{l}\text { Unit } \\
\text { THICK } \\
\text { (m) }\end{array}$ & $\begin{array}{l}\text { Motere } \\
\text { Abova Base } \\
\text { of Section }\end{array}$ & Bed Name & Formation & $\begin{array}{l}\text { Rock } \\
\text { Sumple No. }\end{array}$ & Lithologic Description \\
\hline 0202424.409 & 0.000 & 41.300 & & & & $\begin{array}{l}\text { Top of section. Top of elevation derived from elevation at top of } \\
\text { Contact Egnite in Section M78B7b. }\end{array}$ \\
\hline 0192424.409 & $\mathbf{5 . 0 0 0}$ & 41.300 & & Ludlow & & $\begin{array}{l}\text { Sendators to top (une Section } M 4770 \text { for remaining unite and } \\
\text { thicknesece). }\end{array}$ \\
\hline 0182408.005 & 0.100 & 36.300 & & Ludlow & & Clayetone, ignitic. \\
\hline 0172407.677 & 4.100 & 36.200 & & Ludlow & PMI1 & $\begin{array}{l}\text { Siltetone, clayey, to silty cleystone, heavily weathered; mottled. } \\
\text { some bending. darker toward top. Paleomeg sample taken } 0.15 \mathrm{~m} \\
\text { bolow top of unit: PM1 } 1323^{\circ}-2.5^{\circ} \text { NE. }\end{array}$ \\
\hline 0162394.226 & 0.150 & 32.100 & & Ludlow & PM10 & $\begin{array}{l}\text { Shale, cerbonsceous. Paleomag eample taken from near middla of } \\
\text { unit: PM10 030\%-7॰ NW. }\end{array}$ \\
\hline 0152393.734 & 0.150 & 31.950 & onite & Ludiow & & Lionite. \\
\hline 0142393.242 & 4.600 & 31.800 & & Ludlow & PMOS & $\begin{array}{l}\text { Claystone, sitty, interbedded with clayey cittstone. Paleomes semple } \\
\text { taken } 1.8 \mathrm{~m} \text { above bese of unit: PMS } 355^{\circ}-11^{\circ} \mathrm{E} \text {. }\end{array}$ \\
\hline 0132378.150 & 0.250 & $27.200 \mathrm{c}$ & Contect lignite & Ludlow & & Lignite. \\
\hline 0122377.330 & 0.100 & 26.950 & & Hall Creok & & Shole, lignitic; dark brownish black (5 YR 2/1). \\
\hline 0112377.002 & 1.100 & 26.850 & & Hell Croek & PMOB & $\begin{array}{l}\text { Cleyetone, sitty: light olive oray }(5 \text { Y } 5 / 2) \text {. Peleomed eample taken } \\
40 \mathrm{~cm} \text { above bese of unit: PMB } 247^{\circ}-32^{\circ} \text { NE. }\end{array}$ \\
\hline 0102373.393 & 0.200 & 25.750 & & Hell Creek & & Claystone; oray. \\
\hline 0092372.737 & 1.150 & 25.550 & & Hell Creek & & $\begin{array}{l}\text { Siltstone, clayey siltstone; root traces. Section route transfemed } 25 \\
m \text { to the north. }\end{array}$ \\
\hline 0082368.964 & 1.400 & 24.400 & & Hell Creek & & Stitstone, clayey: with root traces. \\
\hline 0072364.371 & 2.000 & 23.000 & & Hell Creek & & $\begin{array}{l}\text { Sandstone, sitty, very fine-grained, to (or interbedded) cleyey } \\
\text { sittetone; some cross bedding; some root traces. }\end{array}$ \\
\hline 0062357.809 & 5.200 & 21.000 & & Hell Croek & & $\begin{array}{l}\text { Sandatone. fine-orained. fining upwards, cross bedded, with oroenic } \\
\text { material defining the bedding surfeces; preyiah (Hell Creok) color. }\end{array}$ \\
\hline 0052340.749 & 2.400 & 15.800 & & Hell Creek & PMO6. 7 & $\begin{array}{l}\text { Sittstone. clayey. emectitic: orvanic rich in lower portion: highly } \\
\text { weathered "popcom" surfece; oxide shading near contect whth } \\
\text { underlying unit. Paleomes samples taken from lower } 0.25 \text { m of unit: } \\
\text { PM6 } 330^{\circ}-39^{\circ} \mathrm{SW} \text {; PM7 } 015^{\circ}-25^{\circ} \mathrm{NW} \text {. }\end{array}$ \\
\hline 0042332.875 & 3.900 & 13.400 & & Hell Creek & & $\begin{array}{l}\text { Sandstone, crose bedded: grayish color, top marked by } 120-\mathrm{em} \\
\text { thick rexistent yellowish orange interval. }\end{array}$ \\
\hline 0032320.080 & 3.000 & 9.500 & & Hell Croek & PMO4 & $\begin{array}{l}\text { Claystone, sitty, coarser grained near top; fairly sharp upper comtect; } \\
\text { orayish yellow (it's raining egain). Paloomag sample taken } 0.05 \mathrm{~m} \\
\text { above base of unit: PM4 } 030^{\circ}-42^{\circ} \mathrm{NW} \text {. }\end{array}$ \\
\hline 0022310.238 & 0.300 & 6.500 & & Hell Creek & PMO5 & $\begin{array}{l}\text { Siltstons, carbonaceous clayor. Paleomag sample taken from middle } \\
\text { of unit: PM5 } 345^{\circ} 67^{\circ} \mathrm{SW} \text {. }\end{array}$ \\
\hline 0012309.254 & 6.200 & 6.200 & & Hell Creek & PMO1-3 & $\begin{array}{l}\text { Sittetone, clayey, with sitty laminae, three discontinuous } \\
\text { carbonaceous horizons about } 30 \mathrm{~cm} \text { thick; root treces. Peloomad } \\
\text { samples taken } 1.2 \mathrm{~m} \text { above creek bottom: PM1 } 345^{\circ}-47^{\circ} \mathrm{SW} \text {; PM2 } \\
354^{\circ}-46^{\circ} \mathrm{SW} \text {; PM3 } 355^{\circ}-65^{\circ} \mathrm{SW} \text {. }\end{array}$ \\
\hline 0002288.913 & 0.000 & 0.000 & & & & $\begin{array}{l}\text { Section begins at bottom of valley below the erea of M4770, bacated } \\
\text { southeast of Witches Hat section (M4769b) in EK NEK NW\% } 5 W \% \\
\text { sec. } 1 \text { T. } 15 \text { N., R. } 55 \text { E. Section measured by W.D. Peck for } \\
\text { paleomagnetic studies. }\end{array}$ \\
\hline
\end{tabular}




\section{Measured Section M7887a (Witches Hat Section) (Elevations given in feet for use with topographic quadrangle)}

\begin{tabular}{|c|c|c|c|c|c|c|}
\hline $\begin{array}{l}\text { Unit } \\
\text { No. }\end{array}$ & $\begin{array}{l}\text { Elovation } \\
\text { of Top of } \\
\text { Unit }(\mathrm{ft} \text { ) }\end{array}$ & $\begin{array}{l}\text { Unit } \\
\text { THICK } \\
\text { (m) }\end{array}$ & $\begin{array}{l}\text { Moters } \\
\text { Above Bese } \\
\text { of Soction }\end{array}$ & Bod Nemo & Formation & $\begin{array}{l}\text { Fos: } \\
\text { Locen }\end{array}$ \\
\hline 027 & 2281.990 & 0.000 & 50.900 & & & \\
\hline 026 & 2281.990 & 2.900 & 50.900 & $\begin{array}{l}\text { Witches Hat } \\
\text { Sandstone }\end{array}$ & Hell Creak & \\
\hline 025 & 2272.476 & 5.400 & 48.000 & $\begin{array}{l}\text { Witches Hat } \\
\text { Sendstone }\end{array}$ & Hell Creek & \\
\hline 024 & 2254.760 & 0.600 & 42.600 & & Hell Crook & plents \\
\hline 023 & 2252.792 & 0.250 & 42.000 & & Hell Creok & plant: \\
\hline 022 & 2251.972 & 1.600 & 41.750 & & Hell Creek & dinosaur \\
\hline 021 & 2246.723 & 1.100 & 40.150 & & Hell Croek & \\
\hline 020 & 2243.114 & 0.300 & 39.050 & & Hell Creok & \\
\hline 019 & 2242.130 & 0.400 & 38.750 & & Hell Creek & \\
\hline 018 & 2240.818 & 0.150 & $\mathbf{3 8 . 3 5 0}$ & & Hell Creek & plents \\
\hline 017 & 2240.326 & 2.900 & 38.200 & & Hell Creak & \\
\hline 016 & 2230.812 & 1.500 & 35.300 & & Hell Creek & \\
\hline 15 & 91 & 1.300 & 33.800 & & Hell Creok & \\
\hline
\end{tabular}

$\begin{array}{llll}0142221.626 & 2.200 & 32.500 & \text { Hell Croek } \\ 0132214.408 & 2.500 & 30.300 & \text { Hell Croek } \\ & & & \\ 0122206.206 & 0.400 & 27.800 & \text { Hell Creek } \\ 0112204.894 & 5.500 & 27.400 & \text { Hell Creok }\end{array}$

$\begin{array}{llll}0102186.850 & 0.900 & 21.900 & \text { Hell Creok } \\ & & \\ 0092183.8972 .100 & 21.000 & \text { Hell Creok } \\ 0082177.007 & 0.100 & 18.900 & \text { Hell Creok }\end{array}$

\section{Fossil}

Whologic Description
Top of eection.

Sandstone, smectitic portion: Witches Hat Sendstone; represente unit of saddle, with thickness to top of saddle lold unt 231. Sandstone. fine-greined, stacked channels, cross bedded units, levoe scalo trouph cross beds; Witches Hat Sendstone; yollowish oray $15 Y$ 8/11. Thickness to contour line $(2380 \mathrm{ft})$ forming saddb lold Unit 221.

Sittetone, cloyey. fines upwerd to carbonaceous aitty ahale. emectitic; popeom weethered aurfece; dark yellowish brown 110 YA 4/21: soods lold Unit 20l.

Shale, carboneceous, silty, with abundent plant fregmente and charcosl; dusky brown to brownish bleck (5 YR 2/2 to 5 YR 2/1) (old Unit 19].

Sitetone, clayey. fining to silty claystone, smoctitic leame eycle ea Unit 17 [-19]); yellowish gray $(5 Y 7 / 2)$ to light olive brown $(5 Y$ 5/6): dinoseur rubble [old Unit 18].

Cloystone, silty, smectitic; yollowish grey $(5 Y) / 2)$ to light olive brown (5 Y 5/6): clayey top is light alive oray $(5 Y$ 6/1) fold Unit 17). Sittetone; yellowish gray $(5 Y 7 / 2)$ to light olive brown $(5 Y 5 / 6)$ (old Unit 17. A laver 0.3-m thick at $0.4 \mathrm{~m}$ above base of unit]. Siltstone, cleyey, fining upwerds to sitty cleystone, with increasing organic content: smectitic: yollowish gray $(5 \vee 7 / 2)$ to lioht olive brown (5 Y 5/6).

Shale, carbonacoous, brownish gray (5 YR 4/1) to dark yellowish brown (10 YR 4/2): leaves.

Claystono, sitty, to clayey siltstone. popcom weathored, with root traces: yellowish gray $(5$ Y 8/1).

Covered. with orange-brown and black ironatone concretions; forms nose of "flats" (rough and orase covered).

Siktetone, cemented, light olive gray to olive gray 15 Y 5/2 to 5 Y 4/1): lower part is fissile. grayish orange to moderete yollowish brown (10 YR 7/4 to 10 YR 5/4); uppor part hae limonitic concretions. This unit is the uppermost unit messured of this section in Trip $94 f$ before moving up couloe to begin measuring M7887b.

Sandstone, fine-grained, to siltstone, smoctitic, coft, friablo; courser at base (fining upwards): grayish orange (10 YR 7/4), with brown tints.

Siltstone, clayey, to silty claystone, smectitic surfece, and quite moist; light olive gray to light gray 15 Y $6 / 1$ to $N 71$, with limonitic stains along roote and plant stem trash.

Claystone, carbonaceous: black (N 1$)$ and groyish brown 15 YA 3/21. Claystone, silty, to clayey siltetone (eimilar to last): limonitic horizon at 0.8 to $1.5 \mathrm{~m}$ above base. representing debrie on surface between two horizons; light brown (5 YR 6/4) to pale yellowish brown (10 YR 6/2): limonitic color is moderate brown to light brown (5 YR 4/4 to 5 YR 5/61, but variable.

Sandstone, fine-grained, fining upwerds to a very tine-grained sandstone; clay content also increases upwerd: dark yellowish orange (10 YR 6/6): bedding colors inelude yellowish oroye (5 Y 7/2). Claystone, silty, to clayey siltstone (soe Unit 7).

Claystone; moist color of dark yellowish brown (10 YR 4/2). 


\section{Measured Section M7887a (Witches Hat Section)}

(Elevations given in feet for use with topographic quadrangle)

\begin{tabular}{|c|c|c|c|c|c|c|}
\hline $\begin{array}{l}\text { Unit } \\
\text { No. }\end{array}$ & $\begin{array}{l}\text { Elevation } \\
\text { of Top of } \\
\text { Unit (ft) }\end{array}$ & $\begin{array}{l}\text { Unit } \\
\text { THICK } \\
\text { (m) }\end{array}$ & $\begin{array}{l}\text { Moters } \\
\text { Above Bese } \\
\text { of Soction }\end{array}$ & Bed Name & Formation & $\begin{array}{l}\text { Foenil } \\
\text { Locality }\end{array}$ \\
\hline 07 & 76.679 & 1.800 & 18.800 & & Hell Croek & \\
\hline
\end{tabular}

0062170.7744 .800

17.000

Hell Croek

0052155.0263 .200

12.200

Hell Cresk

0042144.5270 .300

9.000

Hell Creok

0032143.5433 .700

8.700

Hell Creek

0022131.4040 .800

5.000 Visitor bed

Hell Creek

0012128.7794 .200

4.200

Hell Crook

0002115.0000 .000

0.000

Lthologic Deseription

Claystone (Units 7 and 91. silty, to clayey siltetone, with smectitic surfece and thonitic stains. The unit, as a whole, has veriable surfece colors, but the central theme is yellowish pray 15 Y 7121: variably oriented colored bands have a subtle datk yellowith orenge 110 YA 6/6).

Sandstone, fine- to very fine-orained. yellowich oray (5 Y 7/2): whth - beal, 0.3-m thick, cemented horizon about $2 \mathrm{~m}$ above bacio, moderate yellowich brawn (10 YR 5/4); with colleterel cequence of smectitic claystone lovers in middle thigh on point berl. sterting below cememted zone: includes jarositic nodules.

Sandstone, very fino-grained, fining upwards to clayey siltetome in two cycles; the second cycle is loess sandy at the bottom and ends on alightly darker oray yollow bands; the bands have a smectitic surface, with the upper cycle boing largely covered; moist color on first "light brown" band is alive gray to light olive gray (5 Y 3/2 to 5 Y 5/2).

Claystone, lignitic; brownich gray to brownish bleck 15 YR $4 / 2$ to 5 YR 2/11.

Claystone, silty, to cloyey siltstone, with a a fow inonstone concretions; light olive gray to yollowich oray 15 Y 6/1 to 5 Y 8/11 (difficult color).

Shalo, carbonaceous, with plant trash and roots: grayish brown to dusky brown (5 YR 3/2 to 5 YR 2/2). This unit forms o dark bend obove the light oray of Unit 1. This is "Rob Kukoweki'e" lionite. Sandstone, modium- to fino-grained, fining upwands, with increasing clay content, smectitic; unit has a dry surface color of hight oray iN $7)$ and a moist color of yellowish oray (5 Y 7/2). In the park, this unit. elono with the derker overlying unit. form a distinctive couplot. Bese of esction on pediment at base of sharp demancation of bluff face, about $15 \mathrm{~m}(50 \mathrm{tt})$ south of Makoshika Stete Park roed elong Cains Coube. The section was measured up the promontory towards Witches Hat. The alevation of the bese of the section is about $2115 \mathrm{ft}( \pm 5 \mathrm{ft}$ ) (revised from $2110 \mathrm{ft}$ of Trip 94f). 


\section{Measured Section M7887b (P-Mag Section) (Elevations given in feet for use with topographic quadrangle)}

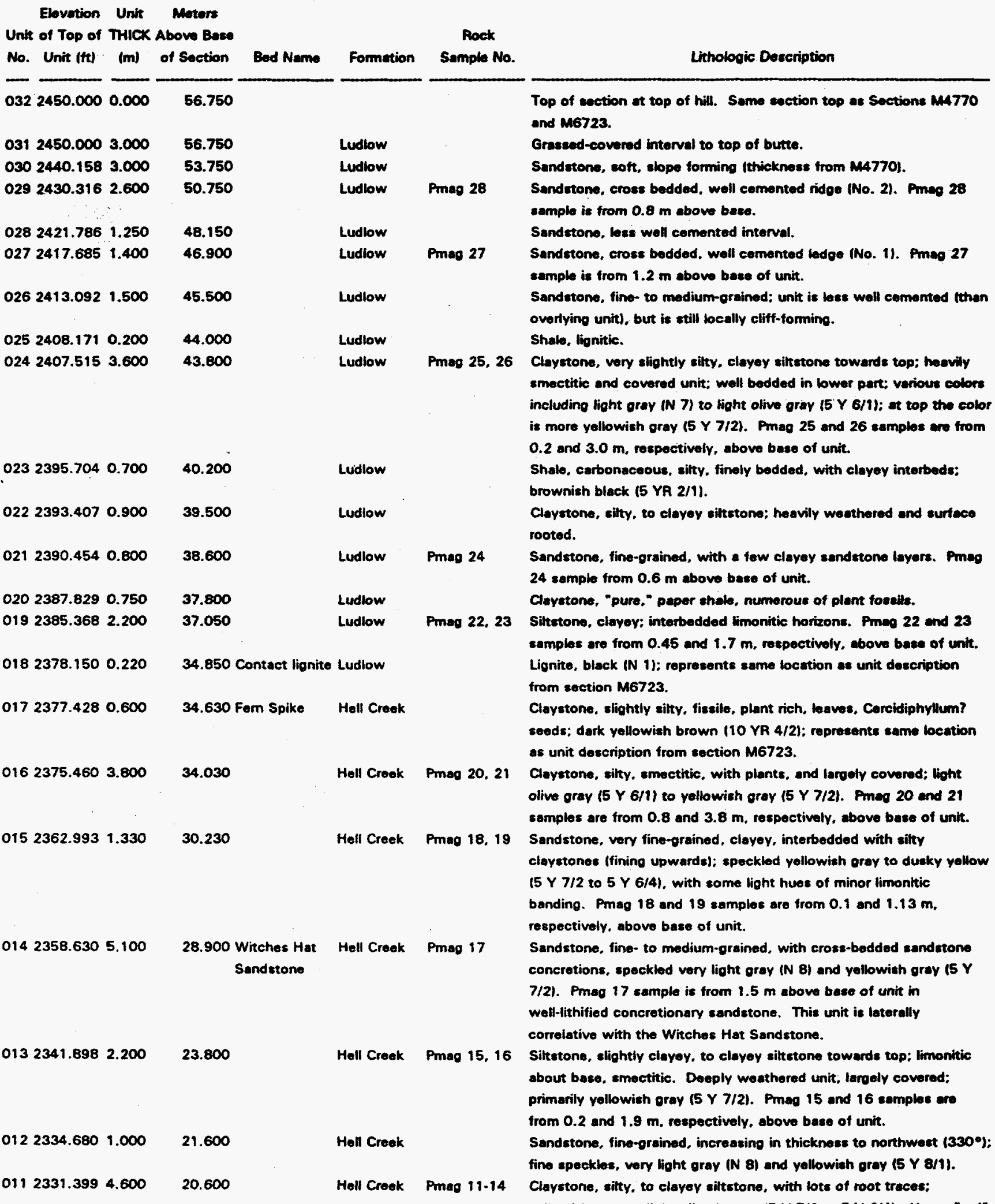

yellowish gray to light olive brown $(5$ Y $7 / 2$ to 5 Y 6/4). Upper "red" 


\section{Measured Section M7887b (P-Mag Section) \\ (Elevations given in feet for use with topographic quadrangle)}

Elavetion Unit Meters

Unit of Top of THICK Above Base

No. Unit (te) (m) of section

(m) of Section

Bod Name
Plock

Semple No.
Lithologic Description
0102316.3074 .000

16.000

0092303.1840 .700

0082300.8870 .800

0072298.2620 .900

0062295.3091 .500

9.600

0052290.3881 .100

0042286.7791 .000

7.000

12.000

11.300

10.500

8.100

$0032283.498 \quad 3.700$

6.000

2.300

1.300

0012268.0781 .300

0.000
Hell Creek Pmag 9, 10

Hell Creek

Hell Creek

Prmag 8

Hell Croek

Hell Croek Pmag 7

Hell Creok Prmag 6

Hell Creek Pmag 5

Hell Creek Pmag 3, 4

Hell Creek Pman 2

Hell Creok Pmap I tint, bout $1 \mathrm{~m}$ thick, with 0.2-0.4-m thick ironstone concretion at top; ironstone surfece is moderete reddish brown to dark yollowish orenge (10 YR 5/4 to 10 YR 6/6). Prime 11, 12, 13, and 14 eamples are from 0.4, 2.0, 4.0. and $3.9 \mathrm{~m}$, respectivily. above bace of unit. Minor lateral shift in section route $30 \mathrm{~m}$ up coulee. Pmag semple 14 was taken $10 \mathrm{~m}$ farther up coulee.

Cleystons, eity, with much plant dobris at base of unit; lower pert hes concretionery horizon directly below eample: semple horizon contains more silt; cleyoy sittetone is yellowish oray (5 Y 7/2). Four to five orpenic cyclos, containino charcoal and amber, pale vollowish brown (10 YA 6/2). End of unit is at top of organic sequence. Pmas 9 and 10 samples are from 0.5 and $3.3 \mathrm{~m}$, respectively. above base of unit. Minor leteral shift in section route $30 \mathrm{~m}$ up coules. Siltstone, clayey, hard: yollowish oray 15 Y 8/11, with brown tint. Claystone, silty; pale yellowish brown (10 YA 6/2), with gray tint. Pmag 8 sample is from $0.25 \mathrm{~m}$ sbove base of unit. sitstone, very slightly clayey: yellowish oray $(5 Y 7 / 2)$, with yollow stringers.

Sitstone, clayey, to silty clavetone; hes fining and coarening upwards cycles; lower part is a smectitic muck; middle of unit is more pure sith and well leminated and light gray (N 7): ot top the unit is a sitty claystone and yellowish gray 15 Y 7/21. Pneg 7 semple is from $1.1 \mathrm{~m}$ above bese of unit.

Sittetone to very fine-grained sandstone; ralatively clean at bese. with clayey interbeds toward top: locelly cemented: yollowich orey (5 Y 7/2); laminated, with different color shades of laminee. Pinea 6 sample is from $0.85 \mathrm{~m}$ above base of unit.

Claystone, slightly silty, plant parts; light olive oray $(5$ Y $6 / 1)$, with pale yellowish brown (10 YR 6/2) tone. Unit coaruens upward increasing in sitt content to clayey siltstone at top: uppor part yellowish gray (5 Y 7/2) to light olive oray (5 Y 5/2). Pmag 5 sample is from $0.2 \mathrm{~m}$ above bese of unit.

Sitstone, clayey, to eilty cleystone; yollowish gray $(5 \mathrm{Y} 7 / 2)$. Unit costeens upward increasing in silt content. Pmas 3 and 4 semples are from $1.6 \mathrm{~m}$ and $2.8 \mathrm{~m}$, respectively, wove base of unit. Sondetone, very fine-grained, bedded, smectitic: yollowish grey $(5 \mathrm{~V}$ 7/2). Pmag 2 sample is from $0.9 \mathrm{~m}$ above bese of unit. Cloystone, silty. to clayey siltstone; pale yellowish brown $110 \mathrm{YR}$ 6/2). Pmag 1 sample is from $0.8 \mathrm{~m}$ above bese of unit. Base of local section on south-facing exposures in narrow to narrowing portion of unnamed coulee. Section taken on trend from west to east towards Contact lignite previously sampled in Section M6723. 
Measured Section M7920 (Boundary Section CC1)

(Elevations given in feet for use with topographic quadrangle)

Old Elevation Unit Moters

Unit Unit of Top of THICK Above Bace

No. No. Unit (ft) $(\mathrm{m})$ of Section

$0150042378.1500 .000 \quad 1.900$

$0140032378.150 \quad 0.220 \quad 1.900$ Contact lignite Ludbw

01300212377.4280 .010

012002 e 2377.3950 .020

$011002 \mathrm{~d} 2377.3290 .020$

$010002 c 2377.2630 .020$

$009002 b \quad 2377.1970 .020$

008002 2377.131 0.020

00700102377.0650 .110

$006001 \mathrm{t} 2376.7040 .020$

005001 e 2376.6380 .210

004001 d 2375.9490 .020

003001 c 2375.8830 .130

$002001 \mathrm{~b} 2375.4560 .020$

001001 a 2375.3901 .060

$000 \quad 2371.9120 .000$
Bad Name

Formation
1.570 Hell Creek

1.460 Hell Creok

1.230

1.210

1.080
Rock

Sample No.

Lithologic Description

Top of section. Elovation for top of lignite taken from Section M7887b.

CC1-93-18. Lianite. Samples CC1-93-19 and 18 taken $5 \mathrm{~cm}$ and $18 \mathrm{~cm}$ 19 above bese of lignite. Thicknese of lignite not given, but taken as $0.22 \mathrm{~m}$ from beal Soction M6723.

Shale, lignitic (teed Unit 8).

Shab, lignitic (see Unit 8).

Shale, hanitic (toe Unit 8).

Hell Craek c61-93-10

Hell Creak cC1-93-11

Hell Creok cC1-93-12

Hell Creak CC1-93-13

Shale, lanitic (ses Unit B): ver thin $(2-3 \mathrm{~mm}$ ) Honitic benses.

Shab, lignitic (cee Unit 8). color mottled (peleosel devolopment?). very thin $(2-3 \mathrm{~mm})$ lignitic lenses.

Holl Creok cc1-93-14 Shab, lignitic, with lignitic wtrinoers; frectures blocky; dark brown; color mottled (paleosol devolopment?), wery thin 12-3 $\mathrm{mm}$ ) lignitic lanses.

Claystone Isee Unit II.

CC1-93-15

Claystone (ree Unit 1 ).

Hell Croek

Claystone (see Unit 11 .

Holl Creek

cc1-93-16

Claystone (see Unit 1),

Hell Creek

Claystone fsee Unit 1$)$.

Hell Creek

cc1-93-17

Hell Creek

Claystone (see Unit 1).

Claystone, fractures blocky, orayish.

Base of section. Section was measured by T.J. Kroeger for pollen studies. 
Measured Section M7921 (Boundary Section CC4)

(Elevations given in feet for use with topographic quadrangle)

\begin{tabular}{|c|c|c|c|c|c|c|c|}
\hline $\begin{array}{l}\text { Old } \\
\text { Unit Unit } \\
\text { No. No. }\end{array}$ & $\begin{array}{l}\text { Elovation } \\
\text { of Top of } \\
\text { Unit (ft) }\end{array}$ & $\begin{array}{l}\text { Unit } \\
\text { THick } \\
(m)\end{array}$ & $\begin{array}{l}\text { Moters } \\
\text { Above Bane } \\
\text { of Section }\end{array}$ & Bed Name & Formation & $\begin{array}{c}\text { Rock } \\
\text { Sample No. }\end{array}$ & Lithologic Deseription \\
\hline 031005 & 2379.725 & 0.000 & 1.300 & & & & $\begin{array}{l}\text { Top of eection. Section CC4-93 reported es very similer to } \\
\text { CC1-93. Elovation for top of lignite taken from Section M7687b } \\
\text { lestimated } \pm 2 \mathrm{ml} \text {. }\end{array}$ \\
\hline 0300040 & 2379.725 & 0.030 & 1.300 & & Ludlow & $C C 4-93-42$ & Sittetone, cleyey (see Unit 18). \\
\hline $029004 f$ & 2379.627 & 0.120 & 1.270 & & Ludiow & & Sitzatone, cleyoy (seo Unit 18). \\
\hline 028004 & 2379.233 & 0.030 & 1.150 & & Ludlow & CC4-93-41 & Sittstone, eleyey (see Unit 18). \\
\hline $027004 d$ & 2379.135 & 0.120 & 1.120 & & Ludlow & & Sittetone, clayey (seo Unit 18). \\
\hline $026004 c$ & 2378.741 & 0.050 & 1.000 & & Ludlow & $C C 4-91-40$ & Sittetone, clayey (tece Unit 18). \\
\hline $025004 b$ & 2378.577 & 0.080 & 0.950 & & Ludiow & & Sittetone, clayey (cee Unit 18). \\
\hline 024004 a & 2378.315 & 0.050 & 0.870 & & Ludlow & CC4-93-39 & $\begin{array}{l}\text { Siltstone, clayey: discrote beds of sitty clay interbedded with } \\
\text { clayey sith on about } 5 \mathrm{~cm} \text { intervals; small-ecale ripple marks: } \\
\text { veriegated color. brown with yellowish strenks. }\end{array}$ \\
\hline $023003 f$ & 2378.151 & 0.020 & $0.820 \mathrm{C}$ & Contact lignite & Ludiow & CC4-93-38 & Lignite; contains silty stringers. \\
\hline 0220030 & 2378.085 & 0.020 & 0.800 & Contect lignite & Ludlow & CC4-93-37 & Lionite. \\
\hline $021003 d$ & 2378.019 & 0.020 & 0.780 & Contect lignite & Ludlow & $\mathrm{CC} 4-93-36$ & Lignite. \\
\hline $020003 c$ & 2377.953 & 0.020 & $0.760 \mathrm{C}$ & Contact lignite & Ludlow & CC4-93-35 & Lignite. \\
\hline $019003 b$ & 2377.887 & 0.020 & 0.740 & Contact lianite & Ludiow & $\mathrm{CC} 4-93-34$ & Lignite. \\
\hline 0180038 & 2377.821 & 0.020 & $0.720 \mathrm{C}$ & Contact lignite & Ludiow & $\mathrm{CC} 4-93-33$ & Lianite. \\
\hline $017002 b$ & 2377.755 & 0.020 & 0.700 & & Hell Creok & $\mathrm{CC} 4-93-23$ & Claystone, lignitic (see Unit 14). \\
\hline $016002 a$ & 2377.689 & 0.020 & 0.680 & & Hell Creek & CC4-93-24 & Claystone, lignitic, with thin lignitic stringers; dark brown. \\
\hline 0150010 & 2377.623 & 0.020 & 0.660 & & Hell Crook & CC4-93-25 & Clayetone, carbonaceous (ese Unit 1 ). \\
\hline $014001 n$ & 2377.557 & 0.020 & 0.640 & & Hell Creok & CC4-93-26 & Clayetone, carbonaceous (see Unit 11. \\
\hline $013001 \mathrm{~m}$ & 2377.491 & 0.020 & 0.620 & & Hell Creok & cC4-93-27 & $\begin{array}{l}\text { Claystone, carbonaceous (s00 Unit 1): derker laminated lignitic } \\
\text { clay zone. }\end{array}$ \\
\hline 0120011 & 2377.425 & 0.020 & 0.600 & & Hell Creok & CC4-93-28 & $\begin{array}{l}\text { Claystone, carbonaceous lese Unit 11: darker laminated lignitic } \\
\text { clay zone. }\end{array}$ \\
\hline $011001 k$ & 2377.359 & 0.020 & 0.580 & & Hell Creek & CC4-93-29 & Claystone, carbonaceous (see Unit 11. \\
\hline $010001 j$ & 2377.293 & 0.020 & 0.560 & & Hell Creek & CC4-93-30 & Cleystone, carbonaceous (seo Unit 1). \\
\hline $009001 i$ & 2377.227 & 0.020 & 0.540 & & Hell Creok & CC4-93-31 & Clayetone, carbonaceous (soe Unit 1). \\
\hline $008001 \mathrm{~h}$ & 2377.161 & 0.020 & 0.520 & & Hell Crook & $\mathrm{cc} 4-93-32$ & Clayetone, carbonaceous (seo Unit 1 ). \\
\hline 0070019 & 2377.095 & 0.030 & 0.500 & & Hell Creek & & Claystone, carbonaceous 1800 Unit 11. \\
\hline 0060011 & 2376.997 & 0.020 & 0.470 & & Hell Crook & CC4-93-22 & Clayctone, carbonacoous (ses Unit 1 ). \\
\hline 005 001e & 2376.931 & 0.170 & 0.450 & & Hell Creek & & Claystone, carbonaceous (see Unit 11. \\
\hline $004001 d$ & 2376.373 & 0.020 & 0.280 & & Hell Croek & CD4-93-21 & Claystone, carbonaceous (sese Unit 1$)$. \\
\hline $003001 c$ & 2376.307 & 0.200 & 0.260 & & Hell Croek & & Claystome, carbonaceous (se0 Unit 1). \\
\hline 0020016 & 2375.651 & 0.020 & 0.060 & & Hell Croak & CC4-93-20 & Cleystone, carbonacoous (see Unit 1 ). \\
\hline $001001 \mathrm{a}=$ & 2375.585 & 0.040 & 0.040 & & Hell Creek & & $\begin{array}{l}\text { Claystone, carbonaceous: horizontal and vertical root traces } \\
\text { abundant, some pedogenic slickenstidos prosent; brownish black } \\
\text { (5 YR 2/11. Bate of unit not exposed. }\end{array}$ \\
\hline 0000002 & 2375.454 & 0.000 & 0.000 & & & & $\begin{array}{l}\text { Base of section. Section was measured by T.J. Kroegor for } \\
\text { pollon studies. }\end{array}$ \\
\hline
\end{tabular}

QbvBTeter(m).MS-aldU-bed-tm-rke-AUNIT.DTF

12/24/95, 18:26 an, p. 1 
Measured Section M7921 (Boundary Section CC4)
(Elevations given in feet for use with topographic quadrangle)

\begin{tabular}{|c|c|c|c|c|c|c|}
\hline $\begin{array}{l}\text { Old } \\
\text { Unit Unit } \\
\text { No. No. }\end{array}$ & $\begin{array}{l}\text { Elovation } \\
\text { of Top of } \\
\text { Unit (ft) }\end{array}$ & $\begin{array}{l}\text { Unit } \\
\text { THick } \\
(m)\end{array}$ & $\begin{array}{l}\text { Moters } \\
\text { Above Bone } \\
\text { of Section }\end{array}$ & Bad Name & Formation & $\begin{array}{c}\text { Rock } \\
\text { Sample No. }\end{array}$ \\
\hline 031005 & 2379.725 & 0.000 & 1.300 & & & \\
\hline 0300040 & 2379.725 & 0.030 & 1.300 & & Ludlow & $C C 4-93-42$ \\
\hline $029004 f$ & 2379.627 & 0.120 & 1.270 & & Ludiow & \\
\hline 0280040 & 2379.233 & 0.030 & 1.150 & & Ludlow & $c c 4-93-41$ \\
\hline $027004 d$ & 2379.135 & 0.120 & 1.120 & & Ludiow & \\
\hline $026004 c$ & 2378.741 & 0.050 & 1.000 & & Ludiow & $\operatorname{cc} 4-91-40$ \\
\hline $025004 b$ & 2378.577 & 0.080 & 0.950 & & Ludlow & \\
\hline $024004 a$ & 2378.315 & 0.050 & 0.870 & & Ludlow & CC4-93-39 \\
\hline
\end{tabular}

$023003 f \quad 2378.1510 .020$ 02200302378.0850 .020 021 003d 2378.019 0.020 $020003 c 2377.9530 .020$ $019003 b \quad 2377.8870 .020$ 018 003a 2377.821 0.020 $017002 b \quad 2377.7550 .020$ 016002 a 2377.6890 .020 $0150010 \quad 2377.6230 .020$ $014001 n 2377.5570 .020$ $013001 \mathrm{~m} 2377.4910 .020$

0.820 Contact lignite Ludlow 0.800 Contact lignite Ludiow 0.780 Contact lignite Ludiow 0.760 Contact lignite Ludiow 0.740 Contact lignite Ludlow 0.720 Contact lignize Ludlow

0.700

Hell Crook

0.680

0.660

0.640

0.620

$0120011 \quad 2377.4250 .020$

0.600

Hell Creok

Hell Crook

Hell Croek

Hell Creok

CC4-93-38

CC4-93-37

CC4-93-36

CC4-93-35

CC4-93-34

CC4-93-33

CC4-93-23

CC4-93-24

CC4-93-25

CC4-93-26

CC4-93-27

$011001 k 2377.3590 .020$

$010001 j \quad 2377.2930 .020$

$009001 i \quad 2377.2270 .020$

008 001h 2377.161 0.020

00700192377.0950 .030

$0060011 \quad 2376.9970 .020$

005 001e 2376.931 0.170

$004001 d 2376.3730 .020$

003001 c 2376.307 0.200

002 001b 2375.6510 .020

0.580

0.560

0.540

0.520

0.500

0.470

0.450

0.280

0.260

0.060

001001 \& 2375.5850 .040

0.040

Holl Creok

CC4-93-2B

Hell Croek

Hell Creek

Hell Creok

Hell Crook

Hell Creek

Hell Creek

Hell Creok

Hell Creok

Hell Croek

Hell Creak

Hell Creek

$000000 \quad 2375.4540 .000 \quad 0.000$
CC4-93-29

CC4-93-30

CC4-93-31

CC4-93-32

CC4-93-22

CD4-93-21

CC4-93-20
Lithologic Description

Top of eection. Section CC4-93 reported as very timiler to CC1-93. Elovation for top of lignite taken from Section M7887b lestimated $\pm 2 \mathrm{ml}$.

Sitstone, clayey (see Unit 18).

Sitstone, clayoy (cee Unit 18).

Sitstone, cloyey (see Unit 18).

Sitstone, clayey (200 Unit 18).

Sittetone, clayey leae Unit 18).

Sittstone, clayey (soo Unit 18).

Sitzetone, clayey; discrete bods of silty cloy interbodded with clayoy silt on about $5 \mathrm{~cm}$ intervals; smait-ecalo ripple marks: variegated color, brown with yellowish streaks.

Lignite; contains sikty stringors.

Lignite.

Lignite.

Lignite.

Lignite.

Lignite.

Claystone, lignitic (soe Unit 14).

Claystono, lignitic, whth thin lianitic stringers; dask brown.

Claystone, carbonaceous leee Unit 11.

Claystone, carboneceous laee Unit 11.

Claystono, carbonaceour (see Unit 1); darker laminated bonitic clay zone.

Claystons, carbonaceous (see Unit 1): darker laminated bignitic clay zone.

Claystone, carbonaceous (see Unit 1 ). Claystone, carbonaceous Isee Unit 1 I. Claystone, carbonaceous lsoe Unit 11 . Claystone, carbanaceous (eee Unit 1). Claystone, carbonaceous (see Unit 11 . Claystone, carbonaceous (ece Unit 11 . Claystone, carbonaceous (see Unit 1). Claystone, carbonaceous (see Unit 1). Claystone, carbonaceous (see Unit 11 . Claystone, carbonaceous lsoe Unit 1).

Claystone, carbonaceous; horizontal and vertical root traces abundent, some pedogenic slickenslides present; brownish bleck (5 YR 2/1). Base of unit not exposed.

Base of section. Section wes measured by T.J. Kroeger for pollen studies. 


\section{Measured Section M7922 (Boundary Section CC5) (Elevations given in feet for use with topographic quadrangle)}

Old Elevetion Unit Motere

Unit Unit of Top of THICK Abow Baes

No. No. Unit (ft) (m) of Section

$037005 \quad 2380.1840 .000 \quad 1.410$

$036004 \mathrm{~m} 2380.1840 .050$

03500412380.0200 .050

1.410

1.360

1.310

1.270

$033004 j 2379.7250 .100$

$032004 i \quad 2379.3970 .030$

1.170

1.140

1.010

030 004a 2378.8720 .030

$029004 f \quad 2378.7740 .010$

028004 e 2378.7410 .030

$027004 d 2378.6430 .040$

$026004 c 2378.5120 .030$

$025004 b \quad 2378.4140 .060$

02400482378.2170 .020

023 003d 2378.151 0.020

022 003c 2378.0850 .030

$\begin{array}{llll}021 & 0.03 b \quad 2377.987 & 0.040\end{array}$

020 003a 2377.8560 .040

$0190020 \quad 2377.725 \quad 0.020$

$018002 n \quad 2377.6590 .020$

$017001 q 2377.5930 .020$

$016001 p \quad 2377.5270 .020$

$0150010 \quad 2377.4610 .020$

$014001 n 2377.3950 .020$

$013001 \mathrm{~m} 2377.3290 .020$

$0120011 \quad 2377.2630 .020$

011 001k 2377.197 0.020

$010001 j 2377.1310 .020$

$009001 i \quad 2377.0650 .020$

008 001h 2376.9990 .020

$007001 \mathrm{~g} 2376.9330 .020$

$006001 f \quad 2376.8670 .060$

005001 e 2376.6700 .020

$004001 d 2376.6040 .170$

$003001 c 2376.0460 .020$

002001 b 2375.9800 .110

001001 a 2375.6190 .020

$000000 \quad 2375.5530 .000$

0.980

0.970

0.940

0.900

0.870

0.660

0.640

0.620

0.600

0.580

0.560

0.540

0.520

0.500

0.480

0.460

0.440

0.420

0.400

0.340

0.320

0.150

0.130

0.020

0.000
Bod Name

Formetion

Rock

Somple No.

Lithologic Deseription

Top of section. Elevetion for top of lignite taken from Section M7887b.

CC5-93-43 Sitstone, clayey (see Unit 22).

Sittstons, clayey fses Unit 22).

cC5-93-44 Siltstone, clayey (sow Unit 22).

Sitstone, clayey (see Unit 22 ).

CC5-93-45 Sitrtone, clayey (see Unit 22 ).

Siltstone, clayey (see Unit 22).

CC5-93-46 Sittetone, clayey (see Unit 22 ).

Sittstone, clayey (see Unit 22 ).

CC5-93-47 Sittone, clayey (see Unit 22).

Sittetone, clayey (ses Unit 22).

CC5-93-48 Sitctone, cleyey (see Unit 22).

Sitstone, clayey (see Unit 22): a unionid impression was collected in the lower $10 \mathrm{~cm}$ of Unit 4 (new Units 22-24).

$0.810 \quad$ Ludiow

0.790 Contact lignite Ludlow

0.770 Contact lignite Ludlow

0.740 Contact lignite Ludiow

0.700 Contact lignite Ludlow
Hell Creok

Hell Creek

Hell Creek

Hell Creek

Hell Creok

Hell Creok

Hell Creok

Hell Creek

Hall Creak

Hell Creek

Hell Creek

Hell Creok

Hell Crook

Hell Creek

Hell Creok

Hell Creek

Holl Croek

Hell Creek

Hell Creek

CC5-93-49 (similar to Unit 4 of $\mathrm{CC} 4-93$ ). Lignite.

CC5-93-50 Lignite.

c05-93-51 Lignite.

CC5-93-52 Lionite.

CC5-93-53 Shale, lignitic; well laminatod and rooted; dark brown.

CC5-93-54 Shale, lignitic; well laminated and rooted; dark brown.

cC5-93-55 Claystone (ces Unit 13).

CC5-93-56 Claytone (see Unit 13).

CC5-93-57 Clayetone leee Unit 13).

CC5-93-58 Clayatone, crumbly; rooted; lighter brown.

CC5-93-59 Sitstone, clayey (see Unit 1$)$

CC5-93-60 Sittstone, clayey (see Unit 1 ).

CC5-93-61 Sittetone, clayey lsee Unit 11.

Siltetone, clayey (zee Unit 1).

CC5-93-62 Sitstone, clayey (see Unit I).

Sittstone, clayey (see Unit 1).

CC5-93-63

Sittctone, clayey (see Unit 1).

Sittetone, clayey (see Unit 1).

CC5-93-64 Sittstone, clayey (see Unit 11.

Siltstone, clayey (zee Unit 1 ).

CC5-93-65

Sitstone, clayey (see Unit 1).

Sittstone, clayey (see Unit 1 ).

CC5-93-66 Sittstone, clayey; well rooted, with abundant slickenslider; dark gray brown.

Base of section. Section was measured by T.J. Kroeger for pollen studies. 


\section{Measured Section M8279 (Hiatt South Section) (Elevations given in feet for use with topographic quadranglel}

Elovetion Unit Motere

Unit of Top of MICK Above Base

No. Unit (tr) (m) of Section

$0152375.0000 .000 \quad 15.525$

$0142375.0002 .250 \quad 15.525$

$0132367.618+500 \quad 13.275$

0122362.6971 .250

11.775

Ludlow

0112358.5960 .500

10.525 unnamed Ludlow lignite

0102356.9560 .150

10.025

Ludlow

0092356.4641 .700

0082350.8870 .500

0072349.2470 .700

0062346.9503 .100

$0052336.780 \quad 2.150$

0042329.7260 .200

0032329.0701 .000

0022325.7890 .225

0012325.0510 .300

0002324.0670 .000
3.875

Ludlow

$\begin{array}{ll}8.175 & \text { Ludlow } \\ 7.675 & \text { Ludlow } \\ 6.975 & \text { Ludlow }\end{array}$

1.725 Ludlow plants

1.525 Ludiow

0.525 Contact lignite Ludiow

$0.300 \quad$ Hell Creek

0.000
Fosad

Localin

Lithologic Description

Top of cection (local).

Sandstone, fine to madium-grained; duaky yellow (5 Y 6/4): to top of local section ebow the locelity.

Conglomarate, intreclastic, forming Hiatt South Quarry (L6424). The rip-up clasts are sity claystones with stems and baves; brown orange concretions ere present above and lateral to conglomerate. Clasts are typically $20-30 \mathrm{~cm}$ with a variety of rounded and fiattened shapes. Unit measured throwgh thickest part of lithosome.

Sandatone, channelform, to base of Hiatt South Locelity (L6424); rip up clest conglomerate; variously caleified and cross bedded; modium grained (in concretions); very light gray (N 8), with yellowish gray tints $(5$ Y $8 / 1)$.

Lignite, good (probably same lignite underfying the Hiat Loculity [L5418]).

Shale, lignitic; brown, dark yellowish brown (10 VR 4/2), but the lignite is coaly plant material.

Siltetone, cleyey, to silky claystone: yellowish gray $(5 \vee 7 / 2)$ to (slightly) light olive oray; includes moderate brown (5 VR 4/4) chips of same litholoor: laterally persiatent unit.

Shale, paper, carboneceaus: grayish brown (5 YR 3/2) to bleck (N 11 . Sitstone: rooted: sherp upper contect: yellowish orey (5 Y 7/2). Sandstone, fine-grained, eleyey, fining upward, crose bedded: oranoe-brown concretions in lower third: oray, sett and pepper ansular quertz, with calcite; cliff former.

Claystone, sliphtly sitty, smectitic, silt contem increases upwands toward top; roote traces, sliekensides, popcom werthered; form: bench: sharp lower and upper contacts; light olive oray (5 Y 6/1) (near top); lighter colored at top.

Claystone, medium gray (N 5 ) to medium light gray (N 6). to yellowish oray (5 Y 7/2); cattailitke plante abundant (marshy). Sandstone, clayey, fining upwards to clayey siltetone; dark yellowish brown (10 YR 4/2): sherp upper contset.

Lignite, vitreous, oood.

Claystone, slightly silty; roots from overiying lignite near the top of unit; dusky yellowish brown (10 YR 2/2) to brownish black (5 YR 2/11. The base of this unit was not determined.

Base of section. Section begins directiy adjacent to an unnamad tributary of Cains Coulee on south-facing exposures, just south of the Hiatt South Locality (L6424) (the Rifle Range is not in view from the base of the section). 
Measured Section M8283 (Sand Creek Overlook Section)
(Elevations given in feet for use with topographic quadrangle)

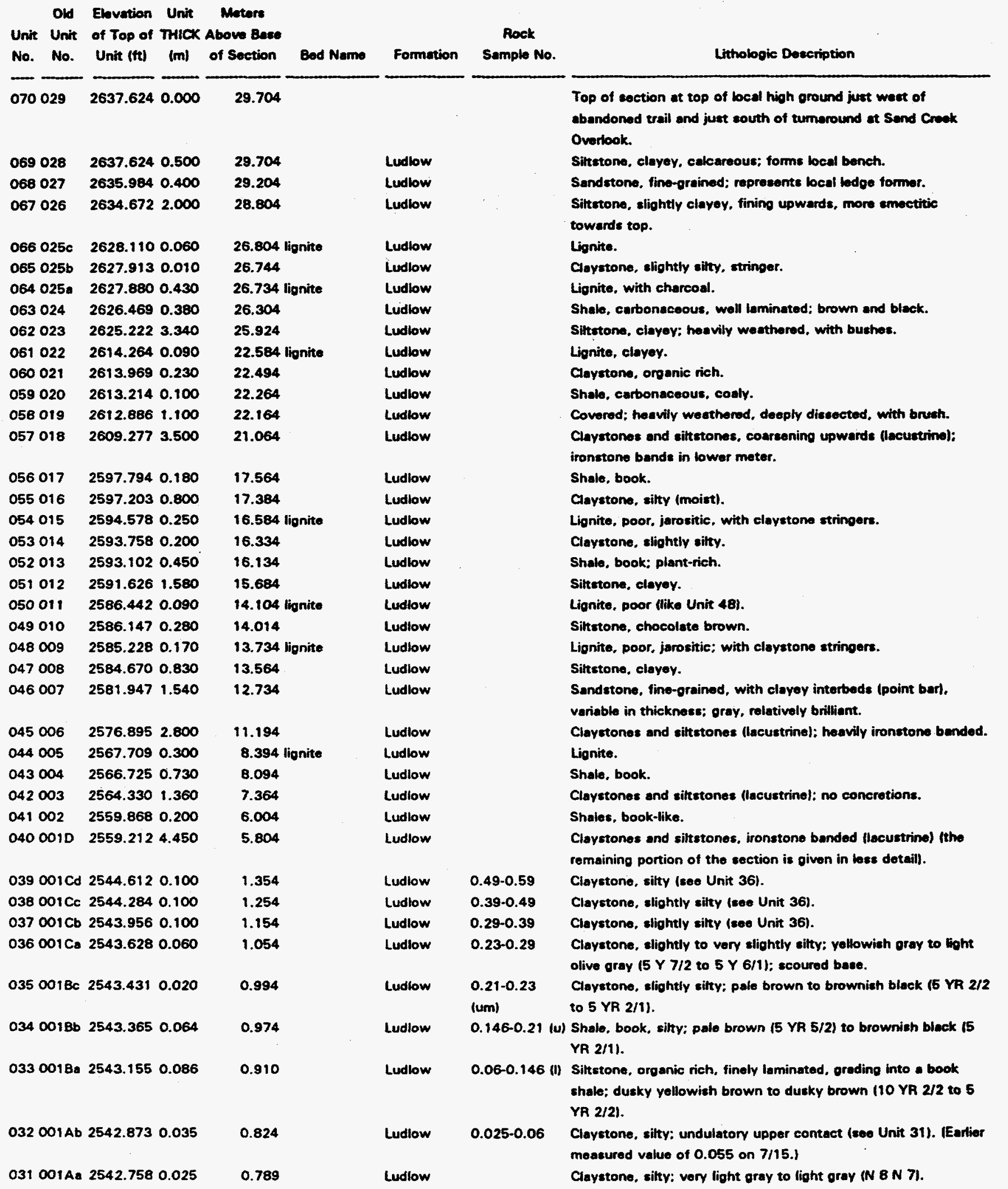




\section{Measured Section M8283 (Sand Creek Overlook Section) (Elevations given in feet for use with topographic quadrangle)}

\begin{tabular}{|c|c|c|c|c|c|c|c|}
\hline $\begin{array}{l}\text { Unit } \\
\text { No. }\end{array}$ & $\begin{array}{l}\text { Old } \\
\text { Unit } \\
\text { No. }\end{array}$ & $\begin{array}{l}\text { Elevetion } \\
\text { of Top of } \\
\text { Unit (tt) }\end{array}$ & $\begin{array}{c}\text { Unit } \\
\text { MHick } \\
\text { (m) }\end{array}$ & $\begin{array}{l}\text { Motere } \\
\text { Above Base } \\
\text { of Section }\end{array}$ & Bed Name & Formation & $\begin{array}{c}\text { Rock } \\
\text { Somple N }\end{array}$ \\
\hline 030 & 001 & 2542.676 & 0.004 & 0.764 & $\begin{array}{l}\text { iridium } \\
\text { enomaly }\end{array}$ & Ludlow & Sampie \\
\hline 029 & 002 & 2542.663 & 0.010 & 0.760 & pink layor & Ludlow & Sample \\
\hline 028 & $003 a$ & 2542.630 & 0.030 & 0.750 & Contect lionite & Ludlow & $0.00-0.03$ \\
\hline 027 & $003 b$ & 2542.532 & 0.030 & 0.720 & Contuct lienite & Ludlow & $0.03-0.06$ \\
\hline 026 & $004 a$ & 2542.434 & 0.020 & 0.690 & & Holl Creok & $0.00-0.02$ \\
\hline 025 & $004 b$ & 2542.368 & 0.020 & 0.670 & & Hell Creek & $0.02-0.04$ \\
\hline 024 & $004 c$ & 2542.302 & 0.020 & 0.650 & & Hell Creek & $0.04-0.06$ \\
\hline 023 & $004 d$ & 2542.236 & 0.020 & 0.630 & & Hell Creek & $0.06-0.08$ \\
\hline 022 & 004 e & 2542.170 & 0.020 & 0.610 & & Hell Creak & $0.08-0.10$ \\
\hline 021 & $004 f$ & 2542.104 & 0.020 & 0.590 & & Hell Creok & $0.10-0.12$ \\
\hline 020 & 0040 & 2542.038 & 0.020 & 0.570 & & Hell Croek & $0.12-0.14$ \\
\hline 019 & $004 h$ & 2541.972 & 0.020 & 0.550 & & Hell Creok & $0.14-0.16$ \\
\hline 018 & $004 i$ & 2541.906 & 0.020 & 0.530 & & Hell Creok & $0.16-0.18$ \\
\hline 017 & $004 j$ & 2541.840 & 0.020 & 0.510 & & Hell Croek & $0.18-0.20$ \\
\hline
\end{tabular}

\begin{tabular}{|c|c|c|c|c|}
\hline $016004 k$ & 2541.7740 .020 & 0.490 & Hell Creok & $0.20-0.22$ \\
\hline 0150041 & 2541.7080 .020 & 0.470 & Hell Creek & $0.22-0.24$ \\
\hline $014004 m$ & 2541.6420 .020 & 0.450 & Hell Creek & $0.24-0.26$ \\
\hline $013004 n$ & 2541.5760 .020 & 0.430 & Holl Crook & $0.26-0.28$ \\
\hline 012005 & 2541.5100 .020 & 0.410 & Hell Creek & $0.28-0.30$ \\
\hline $011005 b$ & 2541.4440 .020 & 0.390 & Hell Creak & $0.30-0.32$ \\
\hline $010005 c$ & 2541.3780 .040 & 0.370 & Hell Creek & $0.32-0.36$ \\
\hline $009005 d$ & 2541.2470 .020 & 0.330 & Hell Croek & $0.36-0.38$ \\
\hline $008006 a$ & 2541.1810 .020 & 0.310 & Hell Croek & $0.38-0.40$ \\
\hline
\end{tabular}

Remaining part of eequence mascured from the bottom up. (Eortior measured velue of 0.025 on $7 / 15$. ) Coyatone, slightly sitty; pale yellowich brown 110 YR 6/21 and pale brown (5 YR 5/2) inot e eacy color to piek). This loyer is relatively well lithified and foims a very minor hadge. th the directly on top of, and edhered to. the pink loyer. This and undertying units were reported to have e dieppeneed iridiem anomaly (enalysis by C.J. Onth: Festovaky, personel comm.. 1995). Unit pert of sequence measured from top down. Sandetone, very fino-orained: grayich orange pink (10 R 8/2) inot an easy color to pick): carbonaceous etringers are beslly present. Unit part of sequence moseured from top down. Lignite, highly fractured and vitreous, with amber. Unit part of sequence measured from top down.

Lignite (seo Unit 28).

Claystone: leminated, undulating: mottied surface with vitreous theen (probably of plent oripin): moderete brown to arayish brown (5 YA 3/4 to 5 YR 2/3) to duaky brown (5 YA 2/2). The lithologies underlying the lignite are variable and inchude brown and green huse of silty claystones. The beal thickneses is aleo variable. Unit part of eequence meesured from top down.

Cloystone, slightly sity: elightly darker than light olive grey $15 \mathrm{Y}$ 5/21; plant debris.

Claystone; slight increase in silt component, with more ebundent plant stome.

Claystone, silty (sce Unit 24).

Claystone, sitty (see Unit 4).

Claystone, silty, with carbonaceous and noncarbonaceous groernish shale clasts.

Cloyetono. silty (see Unit 22).

Claystone, silty, very organic rich, with greenish shele cleste.

Claystone, silty tsee Unit 19).

Claystone, no sitty; organic-rich surfaces; texture is more platy and fiesile; moderate brown (5 YR 4/4) to moderete vellowish brown (10 YA 5/4). A black shale, with charcosl chips (coalification of plant debris), is locatod latoral to this unit. Sharp upper contact: the sodiment is saturated and oozing. forming a local muck, with colors of yellowish brown; organic rich material can be found laterally.

Clayutone (see Unit 17).

Claystone (see Unit 17).

Claytone (see Unit 17).

Clayatone (1000 Unit 17). The base of this unit represents a transition to a more uniformly organic rich clayatone.

Claystone, oroenic rich: brownish black (5 YR 2/1). Unit part of sequence messured from top down.

Claystone (soe Unit 12).

Claystone, slightly silty (soe Unit 12).

Claystone, sitty; root traces, apperently in contect with underlying siltstone.

Sittetone, very slightly cleyey; with minor root traces and other organic fragments: brownish oray (5 YR 4/1) to light brownich

แbVT devi(m).MS-aldU-bed-fm-tke-AUNIT.DTF

12/27/95, B:39 om, D. 2 
Measured Section M8283 (Sand Creek Overlook Section)

(Elevations given in feet for use with topographic quadrangle)

\begin{tabular}{|c|c|c|c|c|c|c|c|c|}
\hline $\begin{array}{l}\text { Unit } \\
\text { No. }\end{array}$ & $\begin{array}{l}\text { Ord } \\
\text { Unit } \\
\text { No. }\end{array}$ & $\begin{array}{l}\text { Elovetion } \\
\text { of Top of } \\
\text { Unit (ft) }\end{array}$ & $\begin{array}{c}\text { Unit } \\
\text { THick } \\
\text { (m) }\end{array}$ & $\begin{array}{l}\text { Motere } \\
\text { Abowe Base } \\
\text { of Section }\end{array}$ & Bed Name & Formation & $\begin{array}{l}\text { Rock } \\
\text { Semple No. }\end{array}$ & Lithologic Doseription \\
\hline & & & & & & & & $\begin{array}{l}\text { grey (5 YR 6/1) ldifficult color to pickl. Unit part of eequence } \\
\text { moasured from top down. }\end{array}$ \\
\hline$\infty$ & Do6b & 2541.115 & 0.030 & 0.290 & & Hell Creok & $0.40-0.43$ & Siktetone, slightly clayey: pale yellowish brown (10 YR 6/2). \\
\hline$\infty 06$ & $006 c$ & 2541.017 & 0.070 & 0.260 & & Holl Crook & $0.43-0.50$ & Sittitone, alightly eloyer (200 Unit 8). \\
\hline$\infty$ & - & 2540.787 & 0.070 & 0.190 & & Hell Creok & $0.50-0.57$ & Sittotane, Sliohtly clayey (ees Unit 8). \\
\hline$\infty$ & 006 & 2540.557 & 0.050 & 0.120 & & Hell Creek & $0.57-0.62$ & $\begin{array}{l}\text { Sittetone, slightly ctoyer (1000 Unit B): moist color olive oray } 5 \text { Y } \\
4 / 11 \text {. }\end{array}$ \\
\hline oos & $006 f$ & 2540.393 & 0.030 & 0.070 & & Hell Croek & $0.62-0.65$ & Sitetone, slightly eleyey lseo Unit 41. \\
\hline$\infty$ & $006 \mathbf{s}$ & 2540.295 & 0.020 & 0.040 & & Hell Crook & $0.65-0.67$ & Sirstone, slightly clayey (ece Unit 4). \\
\hline$\infty 01$ & Do6h & $\begin{array}{l}2540.229 \\
2540.163\end{array}$ & 0.020 & 0.020 & & Hell Croek & $0.67-0.69$ & $\begin{array}{l}\text { Siltatone, slightly clayey; dark yollowish brown (10 YR 4/2). with } \\
\text { olive oray tint } 15 \text { Y } 4 / 1 \text { ). } \\
\text { Base of section (not base of available strata). }\end{array}$ \\
\hline
\end{tabular}

